\title{
COMPOSITING, HOMOGENIZATION, AND CHARACTERIZATION OF SAMPLES FROM HANFORD TANK 241-AN-107
}

OCTOBER 2003

SAVANNAH RIVER TECHNOLOGY CENTER

Westinghouse Savannah River Company Savannah River Site Aiken, SC 29808 
This document was prepared in conjunction with work accomplished under Contract No. DE-AC09-96SR18500 with the U. S. Department of Energy.

\section{DISCLAIMER}

This report was prepared as an account of work sponsored by an agency of the United States Government. Neither the United States Government nor any agency thereof, nor any of their employees, makes any warranty, express or implied, or assumes any legal liability or responsibility for the accuracy, completeness, or usefulness of any information, apparatus, product or process disclosed, or represents that its use would not infringe privately owned rights. Reference herein to any specific commercial product, process or service by trade name, trademark, manufacturer, or otherwise does not necessarily constitute or imply its endorsement, recommendation, or favoring by the United States Government or any agency thereof. The views and opinions of authors expressed herein do not necessarily state or reflect those of the United States Government or any agency thereof.

This report has been reproduced directly from the best available copy.

Available for sale to the public, in paper, from: U.S. Department of Commerce, National Technical Information Service, 5285 Port Royal Road, Springfield, VA 22161, phone: (800) 553-6847, fax: (703) 605-6900

email: orders@ntis.fedworld.gov

online ordering: http://www.ntis.gov/help/index.asp

Available electronically at http://www.osti.gov/bridge

Available for a processing fee to U.S. Department of Energy and its contractors, in paper, from: U.S. Department of Energy, Office of Scientific and Technical Information, P.O. Box 62, Oak Ridge, TN 37831-0062,

phone: (865)576-8401,

fax: (865)576-5728

email: $\underline{\text { reports@ adonis.osti.gov }}$ 
Key Words:

Supernate Composition

Entrained Solids

Sample Analysis

\title{
Retention:
}

Permanent

Key WTP R\&T References:

Test Specification

24590-WTP-TSP-RT-02-010

Test Plan - WSRC-TR-2002-00185, Rev. 1

Test Exceptions

24590-WTP-TEF-RT-02-051

24590-WTP-TEF-RT-02-055

24590-WTP-TEF-RT-03-049

R\&T Focus Area - Characterization

Test Scoping Statement - S-4

\section{COMPOSITING, HOMOGENIZATION, AND CHARACTERIZATION OF SAMPLES FROM HANFORD TANK 241-AN-107}

\author{
K. B. Martin SRTC/WPT \\ C. J. Coleman SRTC/ADS \\ M. S. Hay, SRTC/WPT
}

\section{OCTOBER 2003}

Westinghouse Savannah River Company

Savannah River Site

Aiken, SC 29808

Prepared for the U.S. Department of Energy Under Contract Number DE-AC09-96SR18500

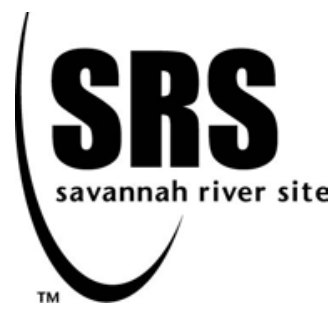


WSRC-TR-2003-00210, REVISION 0

SRT-RPP-2003-00091, REVISION 0

\section{TABLE OF CONTENTS}

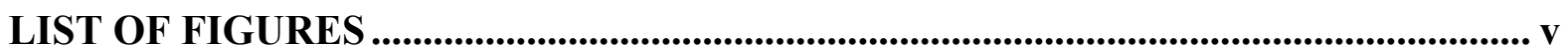

LIST OF TABLES ................................................................................................................... v

LIST OF ACRONYMS ............................................................................................................... vi

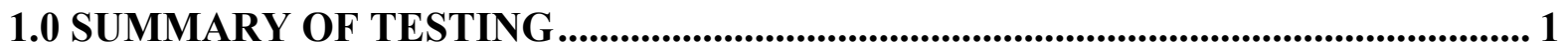

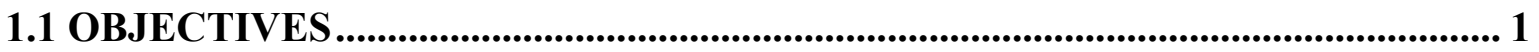

1.2 CONDUCT OF TESTING............................................................................................... 1

1.3 RESULTS AND PERFORMANCE AGAINST OBJECTIVES ................................ 2

1.4 QUALITY REQUIREMENTS.................................................................................... 3

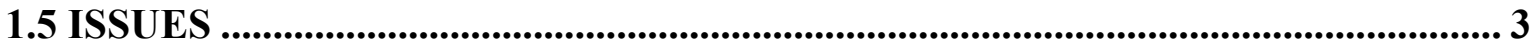

2.0 SAMPLE RECEIVING AND COMPOSITING.................................................................. 5

3.0 HOMOGENEITY TESTING AND SUB-SAMPLING DISCUSSION ......................... 7

4.0 SAMPLE PREPARATION FOR ANALYSIS .................................................................. 9

4.1 PREPARATION OF SAMPLES FOR THE ANALYSIS OF LIQUID

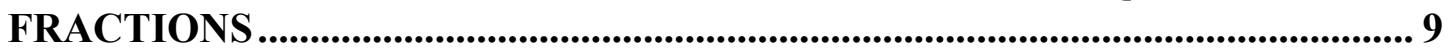

4.2 PREPARATION OF SAMPLES FOR THE ANALYSIS OF SOLIDS

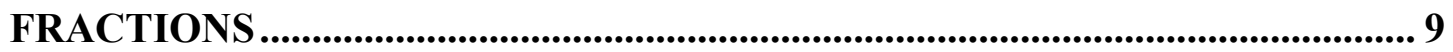

4.3 DOSE RATE LIMITS FOR ANALYTICAL LABORATORIES ............................. 10

5.0 PHYSICAL PROPERTIES MEASUREMENTS ............................................................ 11

5.1 WEIGHT PERCENT SOLIDS ......................................................................................... 11

5.2 DENSITY AND PARTICLE MORPHOLOGY ............................................................ 11

5.3 HEAT CAPACITY AND RHEOLOGY ......................................................................... 12

6.0 ANALYTICAL RESULTS AND DATA EVALUATION ............................................. 13

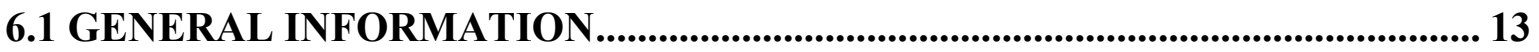

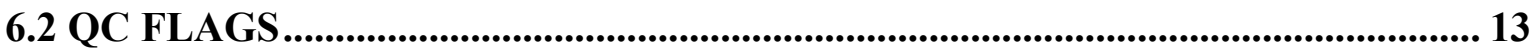

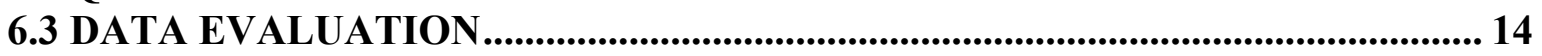

6.3.1 Discussion of Table 6-2, Physical Properties of the As-Received 241-AN-107

Sample...................................................................................................................... 14

6.3.2 Discussion of Table 6-5, Composition of the As-Received 241-AN-107 Filtered

Supernate .......................................................................................................... 15

6.3.3 Discussion of Table 6-6, Composition of the As-Received 241-AN-107 Solids

Microwave Prep .............................................................................................. 16

6.3.4 Discussion of Table 6-7, Composition of the As-Received 241-AN-107 Solids Aqua Regia Prep .................................................................................................... 19

6.3.5 Discussion of Table 6-8, Composition of the As-Received 241-AN-107 Solids

Water Leach Prep ............................................................................................... 21

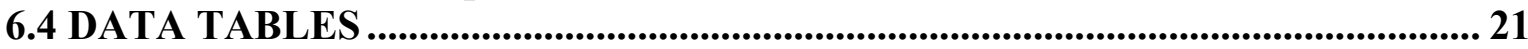

7.0 COMPARISON OF THE AS-RECEIVED SUPERNATE 241-AN-107 SAMPLE TO

SPECIFICATION 7............................................................................................................. 37

8.0 GENERAL DESCRIPTION OF ANALYTICAL PROCEDURES ............................ 39

8.1 INDUCTIVELY COUPLED PLASMA-ATOMIC EMISSION SPECTROSCOPY

8.2 ION CHROMATOGRAPHY FOR ANIONS AND ORGANICS ACIDS .............. 39

8.3 FREE HYDROXIDE AND TOTAL BASE TITRATIONS ....................................... 39

8.4 ATOMIC ABSORPTION SPECTROSCOPY ............................................................ 40 
WSRC-TR-2003-00210, REVISION 0

SRT-RPP-2003-00091, REVISION 0

8.5 AMMONIA ................................................................................................................. 40

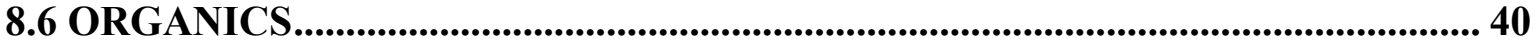

8.7 TOTAL INORGANIC CARBON/TOTAL ORGANIC CARBON ........................... 40

8.8 INDUCTIVELY COUPLED PLASMA-MASS SPECTROMETRY ....................... 41

8.9 ALPHA COUNTING .................................................................................................. 42

8.10 GAMMA SPECTROMETRY .............................................................................. 42

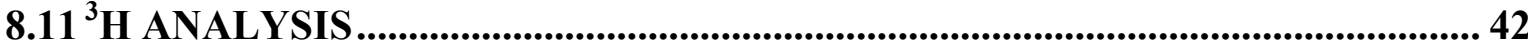

$8.12{ }^{99}$ Tc ANALYSIS (FOR PERTECHNETATE FORM) ............................................. 42

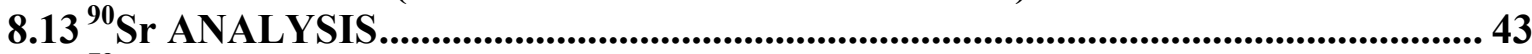

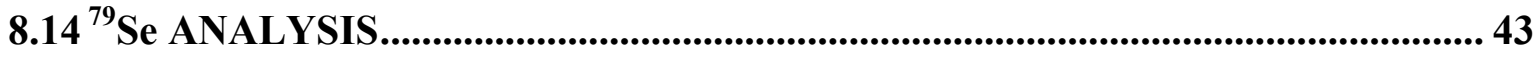

8.15 ALPHA SPECTROSCOPY FOR PLUTONIUM ISOTOPICS.............................. 43

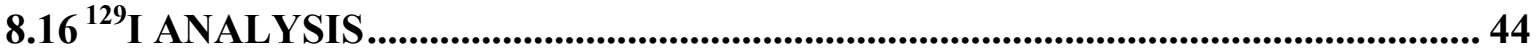

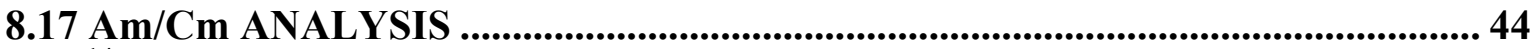

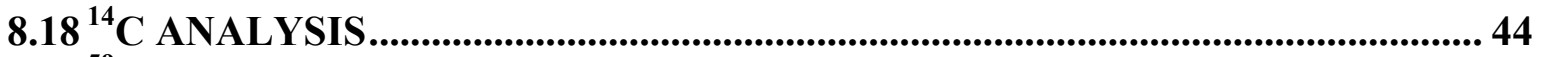

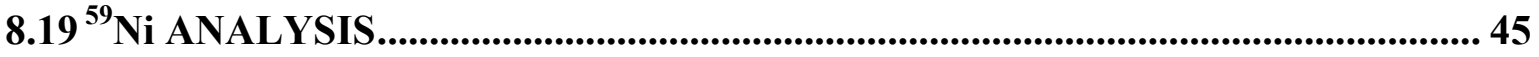

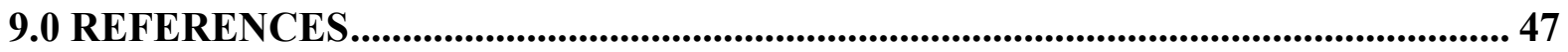

APPENDIX A. CHAIN OF CUSTODY DOCUMENTATION.......................................... 49

APPENDIX B. MICROGRAPHS OF AN-107 DRIED SOLIDS ........................................ 65

APPENDIX C. RAW ANALYTICAL RESULTS ................................................................. 71 


\section{LIST OF FIGURES}

Figure 2-1. As Received AN-107 Sample (a) and Solids (b) ......................................... 5

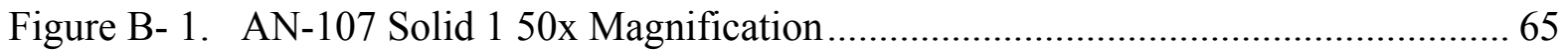

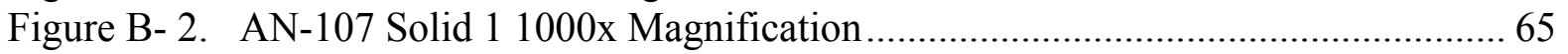

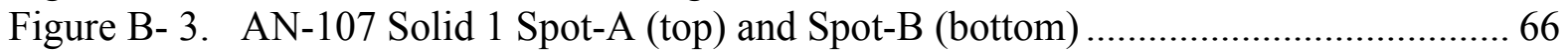

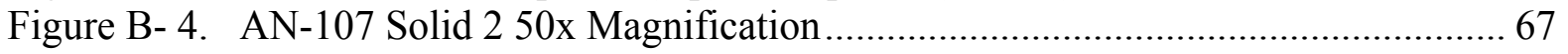

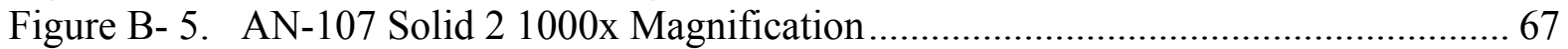

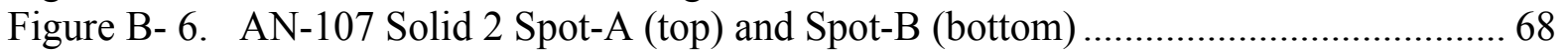

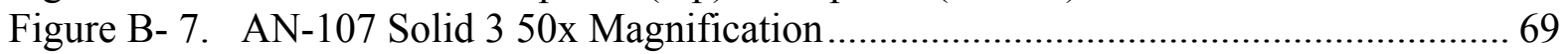

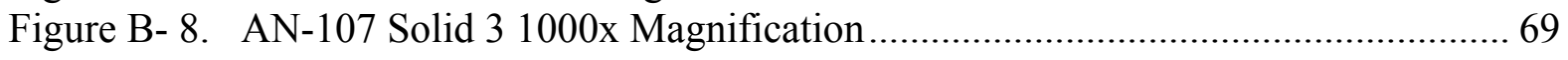

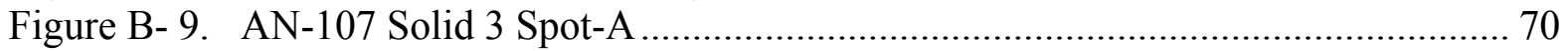

\section{LIST OF TABLES}

Table 2-1. Net Weight of Sample Jars of AN-107....................................................... 6

Table 3-1. Results of the Homogeneity Test for As-Received 241-AN-107 ....................... 7

Table 4-1. Composition of the Analytical Reference Glass-1 Standard ${ }^{4}$............................. 10

Table 6-1. Abbreviations for Analytical Methods in Tables 6-5 through 6-8 …................ 22

Table 6-2. Physical Properties of the As-Received 241-AN-107 Sample .......................... 23

Table 6-3. Rheology Measurements at $25^{\circ} \mathrm{C}$...................................................................... 24

Table 6-4. Rheology Measurements at $40^{\circ} \mathrm{C}$.................................................................. 24

Table 6-5. Composition of the As-Received 241-AN-107 Filtered Supernate.................... 25

Table 6-6. Composition of the Microwave Digested As-Received 241-AN-107 Centrifuged

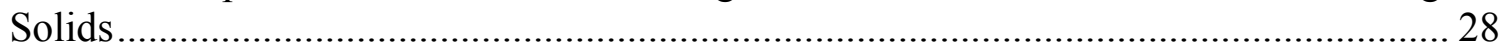

Table 6-7. Composition of the Aqua-Regia Digested As-Received 241-AN-107 Centrifuged

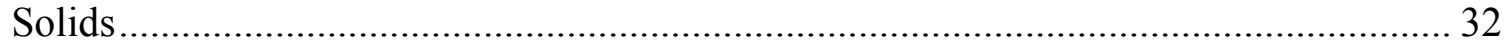

Table 6-8. Composition of the Water Leach Digested As-Received 241-AN-107 Centrifuged Solids............................................................................................... 36

Table 7-1. Comparison of As-Received 241-AN-107 Envelope C Filtered Supernate to Specification 7 Chemical Composition Limits ....................................................... 37

Table 7-2. Comparison of As-Received 241-AN-107 Filtered Supernate to Specification 7

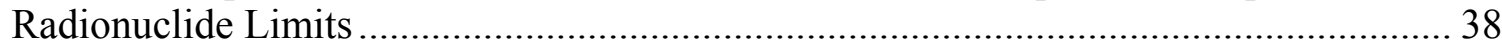




\section{LIST OF ACRONYMS}

Laboratory Control Standard (LCS)

Low-Activity Waste (LAW)

Matrix Spike (MS)

Quality Control (QC)

Quality Control Acceptance Criteria (QCAC)

Relative Standard Deviation (RSD)

River Protection Project-Waste Treatment Plant (RPP-WTP)

Savannah River Technology Center (SRTC)

Total Inorganic Carbon (TIC)

Total Organic Carbon (TOC) 
WSRC-TR-2003-00210, REVISION 0

SRT-RPP-2003-00091, REVISION 0

\subsection{SUMMARY OF TESTING}

As part of the program to provide pretreatment development and testing services to support the River Protection Project-Waste Treatment Plant (RPP-WTP) mission to treat Hanford tank waste, a $\sim 5$ L sample of waste from Tank 241-AN-107 was received at the Savannah River Technology Center (SRTC). The waste sample was characterized and mixed with recycle streams to provide feed for pretreatment testing. The characterization data provides a basis for rational development of pretreatment processes, verification of tank composition, and development of physical design parameters for the pretreatment plant.

\subsection{OBJECTIVES}

The main objectives of this work as defined by the test specification and approved task plan were to:

- Prepare a composite sample from the multiple 241-AN-107 samples.

- Thoroughly mix the composite and confirm that homogenous sub-samples can be drawn for analytical measurements.

- Measure physical properties of the composite sample using one of the homogeneous samples.

- Determine chemical and radiological composition of the liquid and solid fractions using homogenous sub-samples.

- Compare liquid fraction analytical results to the low-activity waste (LAW) feed Specifications 7 requirements.

- Report analytical results.

\subsection{CONDUCT OF TESTING}

A total of eight $500-\mathrm{mL}$ jars and fourteen $125-\mathrm{mL}$ jars of 241-AN-107 tank waste were received at SRTC and composited in an 8-L carboy. A homogeneity test indicated the mixing and sampling system were capable of providing representative samples of the composite. The as-received filtered supernate and the solids collected from centrifuging were analyzed and the supernate found to have a sodium concentration of $\sim 9 \mathrm{M}$. Physical properties were measured on the as-received slurry. The slurry was then separated into solid and supernatant phases by centrifugation and filtration and physical properties were measured on each phase. A portion of the supernatant fraction was removed from the cells for anions and/or cations, inorganic and organic carbon, free hydroxide and total hydroxide determinations. Another portion of the supernatant fraction was heated with nitric acid and hydrogen peroxide in sealed Teflon containers as the sample preparation step prior to elemental and radionuclide determinations. 


\section{WSRC-TR-2003-00210, REVISION 0 SRT-RPP-2003-00091, REVISION 0}

The wet solids that remained after centrifugation and decanting off the supernatant phase were treated with three main sample preparation techniques prior to removing the solutions for instrumental analysis. Hot aqua regia $(3: 1, \mathrm{v} / \mathrm{v}$, concentrated hydrochloric acid and concentrated nitric acid) in a sealed Teflon pressure vessel was used to dissolve the solids for elemental and radionuclide determinations. Wet solids were also dissolved with a mixture of nitric acid, hydrochloric acid, hydrofluoric acid, and boric acid (Microwave Digestion) for elemental and radionuclide determinations. Anion determinations were obtained on solutions after leaching the solids with warm de-ionized water. Additional specific sample preparation techniques were used in the analysis of ${ }^{14} \mathrm{C},{ }^{129} \mathrm{I}$, and ${ }^{79} \mathrm{Se}$.

Microwave digestion is the preferred sample preparation method for solid analyses. Analyte concentrations were higher overall for the microwave digestion. Some matrices require the presence of hydrofluoric acid to achieve complete digestions.

\subsection{RESULTS AND PERFORMANCE AGAINST OBJECTIVES}

All of the main objectives of the characterization for the 241-AN-107 sample were met. However, as part of the reporting objective, data quality requirements were specified for each analyte. Due to the radioactive nature of the sample, dilutions of the raw samples were required to allow removal from the Shielded Cells facility for analysis. These dilutions combined with the presence of very low concentrations of some analytes in the sample make it difficult to meet all of the data quality requirements for all analytes. In those cases where the data quality requirements were not met, a quality control (QC) flag in the data tables identifies which criteria were not met.

The analytical results from the liquid fraction of the 241-AN-107 sample were compared to the Low-Activity Waste feed limits in Specification 7. The 241-AN-107 sample met the contract feed limit specifications for all analytes and radionuclides except transuranic elements.

The Test Specification and Test Plan stated that a comparison will be made of the solids material to Specification 8, which is the Contract Specification related to compositional requirements for HLW materials (Solids). Tank AN-107 solids are primarily listed as saltcake, a material that will likely dissolve during pretreatment. The solids content on a wet basis as measured in this task was relatively low (approximately $7 \mathrm{wt} \%$ ). Further, the weight of solids on a dry weight basis was less than 1\%. (This extremely high water content of AN107 solids had also been noted previously at Battelle - BNFL-RPT-007, Rev. 0.) At 1\% solids, there are not enough solids to allow sufficient material for an accurate measurement of grams solids/gram waste oxide measurement. Therefore, the comparison with Specification 8 was not deemed prudent and was omitted from this work. A Test Exception (24590-WTP-TEF-RT-03-049) was written to omit this scope. 


\subsection{QUALITY REQUIREMENTS}

The test specification provides detailed requirements for the task with respect to quality assurance. The WSRC Quality Assurance Program and the WSRC Quality Assurance Management Plan (WSRC-RP-92-225) were followed during the task. The WSRC Quality Assurance Program was approved by WTP. The appropriate quality assurance requirements for this task from NQA-1-1989 (Part II, Basic and Part III Supplementary Requirements) and NQA-2a-1990, Part 2.7, as indicated by the QA Plan Checklist in Section VIII of the task plan, were applied to this task. The test specification also states that the Department of Energy (DOE) Quality Assurance Requirements and Description (QARD), DOE/RW00333P, Rev. 10, does not apply to this task.

Overall the data quality for the analysis of the 241-AN-107 sample was reasonably good. The quality control of the sample analysis consisted of the use of triplicate sample analysis, blanks, laboratory control standards (LCS), and a matrix spike.

The characterization data presented represents the composition of the 241-AN-107 sample received at SRTC and makes no assertions as to the validity of the data to the tank contents as a whole. Recent experience at SRS indicates a combined sampling and analytical error on the order of $15-20 \%$ associated with obtaining small samples from a well-mixed waste tank.

\subsection{ISSUES}

None 
WSRC-TR-2003-00210, REVISION 0

SRT-RPP-2003-00091, REVISION 0

This page intentionally left blank. 


\subsection{SAMPLE RECEIVING AND COMPOSITING}

A total of eight 500-mL jars and fourteen 125-mL jars of 241-AN-107 tank waste were received at SRTC on May 13, 2002. Sixteen of the sample jars received came from the ten grab samples that were obtained in February 2001 and six of the sample jars received came from two bottles that contained composited samples from a 1998 sampling event of the 241-AN-107 waste tank (Appendix A).

Visual inspection at SRTC showed each jar contained a single dark brown liquid phase with a $\sim 1 / 3$ " to 1" layer of mostly crystalline white solids on the bottom. No separate organic layers were observed in any of the jars. The twenty-two jars were composited into an 8-L polyethylene carboy. Each jar was weighed before and after addition through a 1/8" by 1/8" mesh screen into the carboy. Approximately 125 grams of solids collected on the screen after the compositing, as shown in Figure 2-1. The solids were wetted with supernate and pushed through the screen. The volume of sample in the 8-L carboy after emptying all of the sample jars was $\sim 4.4 \mathrm{~L}$. The total weight of sample added to the carboy was $6.7 \mathrm{~kg}$ based on the measured net weight of each jar. Table 2-1 shows the jar and lab ID taken from each jar; the measured net weight based on the full and empty weight of each jar, and the reported net weight of each jar from the chain of custody documentation (see Appendix A).

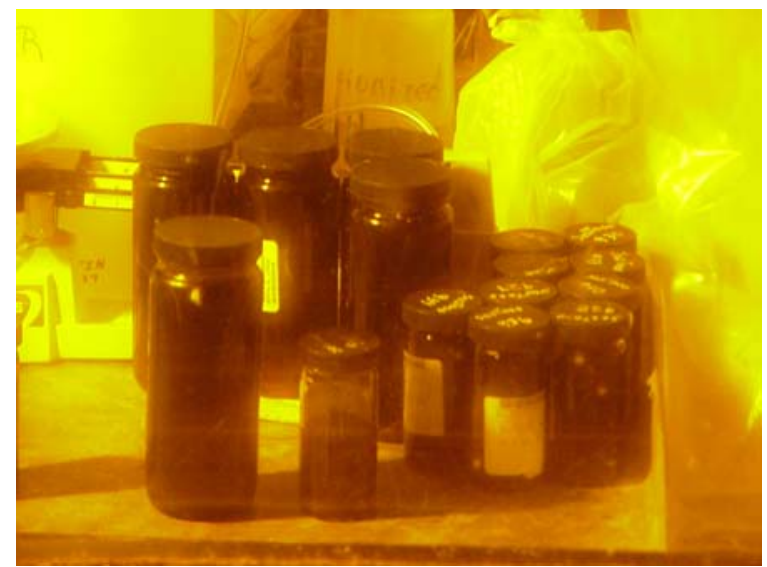

(a)

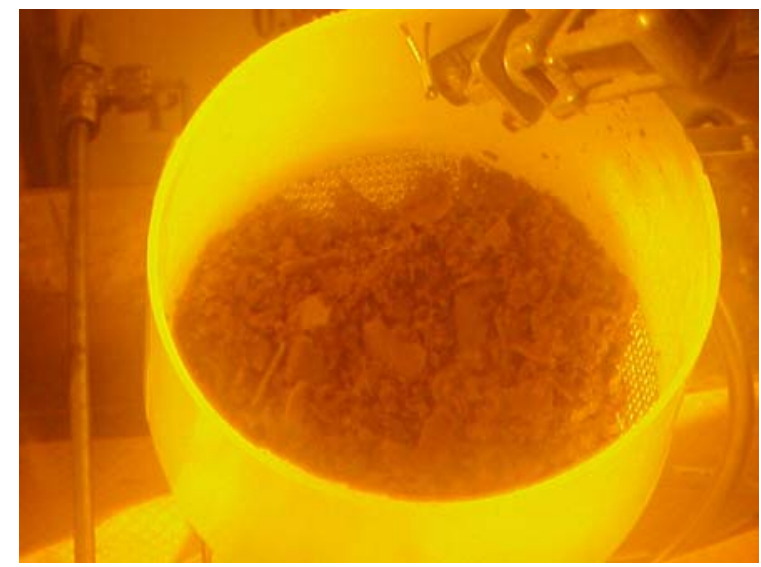

(b)

Figure 2-1. As Received AN-107 Sample (a) and Solids (b) 
WSRC-TR-2003-00210, REVISION 0

SRT-RPP-2003-00091, REVISION 0

Table 2-1. Net Weight of Sample Jars of AN-107

\begin{tabular}{|c|c|c|c|}
\hline Jar ID & Sample ID. & Measured Net Wt (g) & Reported Net Wt. (g) \\
\hline 933 & 7AN-01-02C & 159 & 161.1 \\
\hline 935 & 1998COMP1 & 153 & 157.6 \\
\hline 927 & 7AN-01-03A & 154 & 155.8 \\
\hline 931 & $7 \mathrm{AN}-01-02 \mathrm{~A}$ & 126 & 137.5 \\
\hline 940 & 1998COMP5 & 146 & 147.5 \\
\hline 928 & 7AN-01-03B & 158 & 159.5 \\
\hline 929 & 7AN-01-03C & 162 & 162.8 \\
\hline 930 & 7AN-01-03D & 164 & 168.7 \\
\hline 937 & 1998COMP3 & 99 & 100.6 \\
\hline 932 & 7AN-01-02B & 164 & 165.7 \\
\hline 936 & 1998COMP2 & 154 & 156.7 \\
\hline 941 & 1998COMP6 & 91 & 93.3 \\
\hline 934 & 7AN-01-02D & 163 & 163.9 \\
\hline 939 & 1998COMP4 & 156 & 157.6 \\
\hline PIG 17 & 7AN-01-09 & 643 & 648 \\
\hline PIG 21 & 7AN-01-12 & 119 & 125 \\
\hline PIG 24 & $7 \mathrm{AN}-01-10$ & 668 & 670 \\
\hline PIG 11 & $7 \mathrm{AN}-01-13$ & 623 & 632 \\
\hline PIG 6 & 7AN-01-05 & 668 & 669 \\
\hline PIG 10 & 7AN-01-08 & 668 & 662 \\
\hline PIG 5 & 7AN-01-07 & 652 & 648 \\
\hline \multirow[t]{2}{*}{ PIG 29} & 7AN-01-04 & 649 & 644 \\
\hline & Total & 6739 & 6786 \\
\hline
\end{tabular}




\subsection{HOMOGENEITY TESTING AND SUB-SAMPLING DISCUSSION}

The 8-L carboy was equipped with a mechanical stirrer and a steel dip leg (3/8" ID) connected with tubing (3/8" ID) to a peristaltic pump for sampling purposes. The steel dip leg could be raised or lowered to collect sample from any height in the carboy. A homogeneity test was conducted to ensure that the agitation and sampling system could provide representative samples of the slurry. Twelve $225-\mathrm{mL}$ sub-samples were obtained and collected in graduated cylinders. The sub-samples were obtained from the top, bottom, or midpoint of the original sample height in the 8-L carboy. After settling for 24 hours the volume of settled solids in each of the 12 graduated cylinders was recorded.

Table 3-1 shows the results of the homogeneity test on the as-received 241-AN-107 sample. The average volume percent settled solids of the twelve sub-samples was 4.99 with a percent relative standard deviation of 8.6. The data collected indicated the sampling system provided representative sub-samples independent of sampling height or sampling order. Of the twelve 225 -mL sub-samples, one was kept as an archive sample, one for physical characterization, and one for chemical and radiological characterization. The remaining nine $225-\mathrm{mL}$ subsamples were returned to the carboy for subsequent process testing.

Table 3-1. Results of the Homogeneity Test for As-Received 241-AN-107

\begin{tabular}{|c|c|c|c|c|}
\hline $\begin{array}{c}\text { Cylinder } \\
\text { No. }\end{array}$ & $\begin{array}{c}\text { Sampling } \\
\text { Region }\end{array}$ & $\begin{array}{c}\text { Sample Volume } \\
(\mathbf{m L})\end{array}$ & $\begin{array}{c}\text { Volume of settled } \\
\text { Solids (mL) }\end{array}$ & $\begin{array}{c}\text { Volume Percent } \\
\text { Solids (\%) }\end{array}$ \\
\hline 1 & Top & 224 & 12 & 5.36 \\
\hline 2 & Midpoint & 228 & 12 & 5.26 \\
\hline 3 & Bottom & 224 & 12 & 5.36 \\
\hline 4 & Top & 226 & 10 & 4.42 \\
\hline 5 & Midpoint & 228 & 10 & 4.39 \\
\hline 6 & Bottom & 226 & 10 & 4.42 \\
\hline 7 & Top & 224 & 10 & 4.46 \\
\hline 8 & Midpoint & 224 & 11 & 4.91 \\
\hline 9 & Bottom & 226 & 12 & 5.31 \\
\hline 10 & Top & 225 & 12 & 5.33 \\
\hline 11 & Midpoint & 225 & 12 & 5.33 \\
\hline 12 & Bottom & 228 & 12 & 5.26 \\
\hline
\end{tabular}


WSRC-TR-2003-00210, REVISION 0

SRT-RPP-2003-00091, REVISION 0

This page intentionally left blank.

$-8-$ 
WSRC-TR-2003-00210, REVISION 0

SRT-RPP-2003-00091, REVISION 0

\subsection{SAMPLE PREPARATION FOR ANALYSIS}

\subsection{PREPARATION OF SAMPLES FOR THE ANALYSIS OF LIQUID FRACTIONS}

Samples of the supernate were obtained by centrifuging a portion of the sample, decanting the supernate, and filtering it through a $0.45 \mu$ Nylon filter disc. Portions of the filtered supernate were diluted with de-ionized distilled water or a nitric acid and hydrogen peroxide mixture to reduce the sample activity and allow removal from the Shielded Cells for chemical characterization. The weight of the solids collected was recorded to calculate the weight percent of wet centrifuged solids. Solids collected in the centrifuge tube were not washed to remove interstitial supernate. All sample preparations of the filtered supernate samples were conducted in triplicate. Supernate samples were analyzed for species listed in Table 2 of the test specification ${ }^{1}$.

A blank was prepared concurrently with the sample preparations substituting de-ionized distilled water in place of the sample aliquot.

Additional sample preparations specific to individual analytical methods were conducted by the Analytical Development Section on the samples removed from the Shielded Cells, as necessary.

\subsection{PREPARATION OF SAMPLES FOR THE ANALYSIS OF SOLIDS FRACTIONS}

Triplicate aliquots of the solids collected after centrifugation of the as-received solids were analyzed for the analytes listed in Table 4 of the test specification ${ }^{1}$. Samples were prepared for analysis by aqua-regia digestion, microwave digestion, and a water leach procedure.

Sample preparations for each method consisted of solids being collected by centrifuging a portion of the sample and decanting of the supernate. Solids collected in the centrifuge tube were not washed to remove interstitial supernate and were digested on a wet basis. Samples were further diluted to reduce activity and allow removal from the Shielded Cells.

Digestions of a glass standard containing many of the elements found in tank samples were prepared concurrently with the sample preparations. Table 4-1 lists the composition of the Analytical Reference Glass-1 (ARG-1) glass standard. ${ }^{4}$ A blank was prepared concurrently with the sample preparations consisting of the digestion reagents and incorporated any manipulations and dilutions conducted on the sample. The blank incorporated sample weight measurements for solid conversion data.

Additional sample preparations specific to individual analytical methods were conducted by the Analytical Development Section on the samples removed from the Shielded Cells as necessary. 
WSRC-TR-2003-00210, REVISION 0

SRT-RPP-2003-00091, REVISION 0

Table 4-1. Composition of the Analytical Reference Glass-1 Standard ${ }^{4}$

\begin{tabular}{|c|c|}
\hline Element & Wt\% in Glass \\
\hline $\mathrm{Al}$ & $2.50 \%$ \\
\hline $\mathrm{B}$ & $2.69 \%$ \\
\hline $\mathrm{Ba}$ & $0.079 \%$ \\
\hline $\mathrm{Ca}$ & $1.02 \%$ \\
\hline $\mathrm{Cr}$ & $0.064 \%$ \\
\hline $\mathrm{Cu}$ & $0.003 \%$ \\
\hline $\mathrm{Fe}$ & $9.79 \%$ \\
\hline $\mathrm{K}$ & $2.26 \%$ \\
\hline $\mathrm{Li}$ & $1.49 \%$ \\
\hline $\mathrm{Mg}$ & $0.52 \%$ \\
\hline $\mathrm{Mn}$ & $1.46 \%$ \\
\hline $\mathrm{Na}$ & $8.52 \%$ \\
\hline $\mathrm{Ni}$ & $0.83 \%$ \\
\hline $\mathrm{P}$ & $0.11 \%$ \\
\hline $\mathrm{Si}$ & $22.4 \%$ \\
\hline $\mathrm{Sr}$ & $0.003 \%$ \\
\hline $\mathrm{Ti}$ & $0.69 \%$ \\
\hline $\mathrm{Zn}$ & $0.016 \%$ \\
\hline $\mathrm{Zr}$ & $0.096 \%$ \\
\hline & \\
\hline & \\
\hline
\end{tabular}

\subsection{DOSE RATE LIMITS FOR ANALYTICAL LABORATORIES}

Samples sent to the analytical laboratories require dose rates of $<10 \mathrm{mrem} / \mathrm{hr}$ whole body dose and $<1000 \mathrm{mrem} / \mathrm{hr}$ extremity dose. In order to avoid exceeding the dose rate limits and the need for re-preparing the samples, dilutions were made targeting a whole body dose rate of between $2-5 \mathrm{mrem} / \mathrm{hr}$. This working dose rate range provides some cushion against the unavoidable presence of contamination on the outside of the sample bottles. Additionally, sample handling in the cells, such as pipetting, weighing, or transferring from one container to another invariably leads to some contamination of the sample. Efforts to minimize the level of contamination include regular cleaning of the manipulator fingers, cleaning of cell surfaces, and the use of clean supplies. Blanks prepared in the Shielded Cells in the same manner as the sample provide some indication of the level of contamination introduced. 


\subsection{PHYSICAL PROPERTIES MEASUREMENTS}

\subsection{WEIGHT PERCENT SOLIDS}

The weight percent total solids in the sample were measured in the Shielded Cells using a conventional drying oven at $115^{\circ} \mathrm{C}$. The weight percent dissolved solids in a sample of the filtered supernate were measured in the same manner. The weight percent insoluble solids and soluble solids in the sample were calculated from the measurements of the weight percent total solids and the weight percent dissolved solids. Calculation of the weight percent insoluble solids of samples in this manner avoids difficulties associated with reproducibly measuring the insoluble solids directly. Equations 1 and 2 allow calculation of the weight percent of insoluble and soluble solids from the weight percent total solids and dissolved solids measurements. The weight percent soluble solids gives the mass of the dissolved solids in the supernate expressed as a percentage of the mass of the sample. The weight percent of insoluble solids represents the mass of insoluble solids expressed as a percentage of the mass of the sample. All measurements were made in triplicate.

\section{Equation 1}

Equation 2

$$
w_{\text {is }}=\left(w_{t s}-w_{d s}\right) /\left(1-w_{d s}\right)
$$

$$
\mathbf{w}_{\text {SS }}=\mathbf{w t s}_{\mathbf{t s}}-\mathbf{w i s}
$$

where:

$\begin{array}{ll}\mathrm{w}_{\mathrm{ds}}=\text { weight fraction of dissolved solids } & \text { (wt dissolved solids/wt of supernate) } \\ \mathrm{wts}_{\mathrm{ts}}=\text { weight fraction of total solids } & \text { (wt total solids/wt of sludge slurry) } \\ \mathrm{w}_{\mathrm{is}}=\text { weight fraction of insoluble solids } & \text { (wt insoluble solids/wt of sludge slurry) } \\ \mathrm{w}_{\mathrm{Ss}}=\text { weight fraction of soluble solids } & \text { (wt dissolved solids/wt of sludge slurry) }\end{array}$

\subsection{DENSITY AND PARTICLE MORPHOLOGY}

Density measurements were made in the Shielded Cells on both the total sample and the filtered supernate. The temperature in the Shielded Cells varies between $\sim 18-25^{\circ} \mathrm{C}$ based on the temperature outside the building. The temperature was recorded for all density measurements and noted in the tables of analytical results.

The Contained Scanning Electron Microscope (CSEM) was used to study the physical features of the AN-107 particles and their structural relationships. It was used to produce an EDX (energy dispersive x-ray) spectrum, which gives a qualitative elemental analysis of the sample constituents. Samples were measured in triplicate. Particle size measurements could not be obtained because the dose rates were too high for the quantity of sample required for this analysis. Qualitative analysis of the AN-107 solids shows the following elements: Na, S, $\mathrm{Cl}, \mathrm{K}, \mathrm{Ca}, \mathrm{Cr}, \mathrm{Mn}, \mathrm{Fe}, \mathrm{Ni}, \mathrm{Al}$, and U. Micrographs are shown in Appendix B. The solids are classified as saltcake and considered precipitated salts. SEMs indicate two types of chemical composition in the particles: one dominated by salts, e.g. Na, and the other high in metals. This contributes to the heterogeneity of the solids. 


\subsection{HEAT CAPACITY AND RHEOLOGY}

Heat capacity measurements were performed on the slurry sample in triplicate using a Differential Scanning Calorimeter. Rheological measurements were performed in triplicate using a concentric cylinder geometry head. Measurements were performed at $25^{\circ} \mathrm{C}$ and $40^{\circ} \mathrm{C}$. 


\subsection{ANALYTICAL RESULTS AND DATA EVALUATION}

\subsection{GENERAL INFORMATION}

Table 6-5 through Table 6-8 provide the chemical and radiochemical composition of the as-received samples of the 241-AN-107 tank waste samples received at SRTC. The tables include the results of all replicates, blanks, laboratory control and matrix spike recoveries, and quality control flags within each table to allow easy identification of data quality. Analytical results for liquid samples use units of $\mathrm{mg} / \mathrm{L}$ or $\mathrm{mCi} / \mathrm{L}$, while results for solid samples use $\mathrm{mg} / \mathrm{kg}$ or $\mathrm{mCi} / \mathrm{kg}$ units. The following list identifies the data tables included in this section with a brief description of the samples analyzed:
6-1
Abbreviations of analytical methods used for each analysis
$6-2$
Physical properties of the as-received 241-AN-107 sample
6-3
Rheology measurements at $25^{\circ} \mathrm{C}$
$6-4$
Rheology measurements at $40^{\circ} \mathrm{C}$
6-5
Chemical (inorganic and organic) and radiochemical composition of the filtered centrifuged supernate from the as-received 241-AN-107 sample
6-6
Chemical (inorganic) and radiochemical composition of the solids centrifuged from the as-received 241-AN-107 sample. The samples were digested using a microwave digestion method prior to analysis.
Chemical (inorganic) and radiochemical composition of the solids centrifuged from the as-received 241-AN-107 sample. The samples were digested using aqua-regia prior to analysis.
6-8
Chemical (inorganic and organic) composition of the solids centrifuged from the as-received 241-AN-107 sample. The samples were digested using a water leaching procedure prior to analysis.

\subsection{QC FLAGS}

The analytical result tables include a quality control (QC) flag in the last column to indicate failure to meet the quality control requirements stated in the test specification. The test specification and approved task plan for the characterization of the 241-AN-107 samples set requirements for the minimum reportable quantity (MRQ), the percent relative standard deviation (\%RSD) for the three replicate samples, the percent recovery of the laboratory control standard (LCS), and the percent recovery of the matrix spike (MS) analysis for each analyte. In addition, analyses in which the concentration of the analyte in the blank exceeded $5 \%$ of the concentration in the sample and instances in which the analyte concentration detected in the samples was less than ten times the detection level for the sample were also flagged. 
The following defines the QC flags used in the tables:

None Analyte meets all QC requirements.

$\mathrm{U}_{\mathrm{M}} \quad$ Analyte does not meet the MRQ requirement.

$\mathrm{U}_{\mathrm{R}} \quad$ Analyte does not meet the \% RSD requirement.

$\mathrm{U}_{\mathrm{L}} \quad$ Analyte does not meet the percent recovery of the LCS requirement.

$\mathrm{U}_{\mathrm{S}} \quad$ Analyte does not meet the percent recovery of the MS requirement.

$\mathrm{U}_{\mathrm{B}} \quad$ Analyte concentration in the blank exceeds 5\% of the concentration measured in the sample.

$\mathrm{U}_{\mathrm{E}} \quad$ Analyte concentration measured at less than ten times the detection level for the sample.

Most of the QC failures can be attributed to low concentrations present in the sample or low concentrations in the analytical samples due to the dilution necessary to allow removal of the samples from the Shielded Cells for analysis in the ADS laboratory hoods. In particular, meeting the MRQ requirement depends heavily on the dilution required for handling the sample. In other cases, for example digestion of solid samples, a large percentage of the uncertainty is due to the sampling method specified by the test specification. Sampling the solids using centrifigation does not work well with samples having concentrated supernates and low insoluble solids that can't be washed to remove interstitial supernate. The solids are classified as saltcake and considered precipitated salts. The SEMs indicate two types of chemical composition in the particles, one dominated by salts, e.g. Na, the other high in metals. This also contributes to the heterogeneity of the solids. Extensive sample preparation in the Shielded Cells may lead to contamination of the sample as evidenced by significant concentrations of radionuclides in the blanks and standards. The presence of contamination in the sample generally led to large \%RSD for the replicate analyses. With the low concentration of many of the radionuclides in the sample, a small amount of contamination leads to large errors in the measurement.

\subsection{DATA EVALUATION}

\subsubsection{Discussion of Table 6-2, Physical Properties of the As-Received 241-AN-107 Sample}

Data for the volume percent centrifuged solids and weight percent insoluble solids show high percent relative standard deviations for the replicate measurements. Both measurements have inherently low precision owing to the low solids concentration and presence of variable amounts of interstitial supernate trapped in the solids. In both measurements, the solids were not washed free of interstitial supernate. It is likely a substantial percentage of the solids would dissolve during washing. The amount of supernatant contamination can affect the weight and thus the final concentration significantly for small sample sizes. 
WSRC-TR-2003-00210, REVISION 0

SRT-RPP-2003-00091, REVISION 0

\subsubsection{Discussion of Table 6-5, Composition of the As-Received 241-AN-107 Filtered Supernate}

- Many of the elements from the ICP-ES analysis (IE designator in table) were flagged as $\mathrm{U}_{\mathrm{E}}$ since the values were less than 10 times the detection limits. $\mathrm{Ag}, \mathrm{Li}, \mathrm{Mg}, \mathrm{P}, \mathrm{U}$, and V were flagged as $U_{M}$ for not meeting the required MRQ. These failures were attributed to the dilutions necessary to allow removal from the Shielded Cells for analysis. The unmet MRQ for $\mathrm{P}$ and $\mathrm{U}$ is not critical since the concentrations are well above the detection limit.

- Sodium results by ICP-ES and AA show good agreement. The difference between the two methods is less than $10 \%$.

- High relative standard deviation for ${ }^{237} \mathrm{~Np}$ from ICP-MS is attributed to the low concentration in the sample. W failed to meet the matrix spike recovery and relative standard deviation requirements. It is attributed to $\mathrm{W}$ being a contaminant in the system.

- High relative standard deviation for TIC/TOC is attributed to the limitation of the method. Samples that contain complex organic acids may not be entirely combusted by the method. This is evident when comparing the sample against the serial dilution. Serial dilution analyzed higher than the undiluted sample indicating incomplete combustion in the original measurement.

- Total base and free OH were flagged for not meeting the MRQ. The unmet MRQ for total base is of minimal impact because the total base concentration is well above the detection limit.

- Sulfur concentrations obtained from IC (as sulfate) and ICP-ES show reasonable agreement. The difference is approximately $25 \%$.

- Phosphorus analysis by ICP-ES yielded a result approximately two times less than the concentration measured by IC (as phosphate). The ratio between the two measurements should be a factor of 3 if the phosphorus is present entirely as phosphate.

- Acetate was flagged as not meeting the required recovery for the matrix spike. Carbonate showed inconsistent data that caused it to fail the \%RSD, matrix spike recovery, and the laboratory control standard recovery.

- ${ }^{90} \mathrm{Sr}$ was flagged for not meeting the matrix spike recovery. The matrix spike recovery was high, but this is not judged to impact data quality. The recovery was poor due to the relatively large amount of ${ }^{90} \mathrm{Sr}$ in the sample relative to the added ${ }^{90} \mathrm{Sr}$ spike. However, each individual analysis in the batch is yielded independently using a neutron activation analysis (NAA) step, so the data is technically sound and defensible.

- ${ }^{154} \mathrm{Eu},{ }^{155} \mathrm{Eu},{ }^{60} \mathrm{Co},{ }^{126} \mathrm{Sb} /{ }^{126} \mathrm{Sn}$, and ${ }^{125} \mathrm{Sb}$ from gamma spectrometry were flagged as not meeting the \%RSD. Sn and Sb isotopes were flagged for not meeting the MRQ requirements. This is attributed to the $\mathrm{Sn}$ and $\mathrm{Sb}$ isotopes being within an order of magnitude of the detection limits for the respective samples analyzed and low sample concentration. 
- Results for the ${ }^{99} \mathrm{Tc}$ pertechnetate are reported as upper limits due to interference evident in the liquid scintillation analysis. ${ }^{99} \mathrm{Tc}$ measured as pertechnetate and the total ${ }^{99} \mathrm{Tc}$ measured differ by $\sim 51 \%$, indicating approximately half of the technetium is in forms other than pertechnetate.

- ${ }^{129}$ I was flagged for not meeting the $\%$ RSD requirement. The failure to meet the $\%$ RSD requirement was attributed to low concentrations present in the sample and the dilutions necessary to allow removal from the Shielded Cells for analysis.

- $\quad{ }^{14} \mathrm{C}$ analysis was flagged for not meeting the required MRQ and \%RSD. All sample results were within an order of magnitude of analytical detection limits, the beta spectrum of the $3^{\text {rd }}$ replicate and the serial dilution still showed evidence of residual higher energy beta, and as a result were caveated as upper limits. The failure to meet the MRQ and $\%$ RSD requirement was attributed to low concentrations present in the sample and the dilutions necessary to allow removal from the Shielded Cells for analysis.

- $\quad{ }^{137}$ Cs concentration measured by gamma spectroscopy and ICP-MS show agreement with a difference of approximately $23 \%$. The ICP-MS measurement is biased high due to $\mathrm{Ba}$ concentrations in the supernate.

- Higher energy beta was observed in the ${ }^{79}$ Se spectra so the results are caveated as upper limits.

- $\quad{ }^{241} \mathrm{Am},{ }^{243} \mathrm{Am}$, and ${ }^{244} \mathrm{Cm}$ were flagged for not meeting the required \%RSD. ${ }^{243} \mathrm{Am}$ and ${ }^{242} \mathrm{Cm}$ were flagged for not meeting the required minimum reportable quantity. The blank sample showed ${ }^{241} \mathrm{Am},{ }^{243} \mathrm{Am},{ }^{242} \mathrm{Cm}$, and ${ }^{244} \mathrm{Cm}$ contamination. A potential positive bias for the ${ }^{242} \mathrm{Cm}$ may exist if any ${ }^{252} \mathrm{Cf}$ is present in the samples.

\subsubsection{Discussion of Table 6-6, Composition of the As-Received 241-AN-107 Solids Microwave Prep}

- Several of the elements were flagged for not meeting the required \%RSD. Two sets of samples were analyzed and the problem of high RSDs occurred in both sets. This is attributed to the solid/liquid separation method. Many of what are generally thought of as solids associated analytes (e.g., $\mathrm{Mn}, \mathrm{Fe}, \mathrm{Ni}, \mathrm{Pb}, \mathrm{Zn}$ ) are as high or higher in the supernate than in the solids for AN-107 because of the complexants in the tank. Several of the elements were flagged for not meeting the required MRQ and having values less than 10 times the detection limit. These failures were attributed to low concentrations present in the sample and the dilutions necessary to allow removal from the Shielded Cells for analysis. 


\section{WSRC-TR-2003-00210, REVISION 0 SRT-RPP-2003-00091, REVISION 0}

- ICP-ES data set (IE designator in table) for the second solid digestion was used because of significant contamination of the blank and glass standard in the first data set. Silver, barium, magnesium, zinc, and titanium were flagged for not meeting the required MRQ. Copper was flagged for the blank exceeding $5 \%$ of the sample concentration. Calcium, iron, manganese, sodium, nickel, and strontium were flagged for not meeting the \%RSD. Sulfur and silicon were flagged for the blank exceeding 5\% of sample concentration and not meeting the required $\%$ RSD. Aluminum was flagged for the blank exceeding $5 \%$ of sample concentration, not meeting MRQ and values less than 10 times the detection limits. Lanthanum was flagged for the blank exceeding $5 \%$ of sample concentration, not meeting the required \%RSD, and MRQ. Vanadium was flagged for the blank exceeding $5 \%$ of sample concentration, not meeting the required $\% \mathrm{RSD}$, and values less than 10 times the detection limits. Chromium was flagged for not meeting the required \%RSD and MRQ. Cadmium was flagged for values less than 10 times the detection limits and not meeting the required \%RSD. Phosphorus was flagged for values not meeting the required MRQ and values less than 10 times the detection limits.

- Aluminum, chromium, lead, and lanthanum unmet MRQs are of minimal impact since the concentrations present are well above the detection limits.

- $\mathrm{Cu}, \mathrm{S}, \mathrm{V},{ }^{238} \mathrm{U},{ }^{133} \mathrm{Cs}$, and Ce by ICP-ES and ICP-MS may be biased high due to the presence of a significant interference or contamination observed in the glass standard.

- Sodium did not meet the \%RSD by AA which was attributed to variable amounts of interstitial liquid in the solids at high sodium concentrations and selenium did not meet the required MRQ. This was attributed to low concentration in the sample.

- Sodium by AA and ICP-ES are in good agreement. The difference between the two measurements is $0.2 \%$.

- Thorium, molybdenum, ruthenium, and rhodium were flagged for not meeting the required MRQ and \%RSD. This was attributed to low sample concentration. Thorium unmet MRQ is of minimal impact since the concentrations present are above the detection limit.

- $\mathrm{U}^{235}$ and Cobalt by ICP-MS were flagged for not meeting the \% recovery of LCS.

- Vanadium was flagged for the blank exceeding 5\% of the sample concentration and not meeting the required \% recovery of LCS. This is attributed to a contaminant in the system.

- Selenium, lead, antimony, barium, platinum, thallium, plutonium, tellurium, bismuth, and neodymium were flagged for not meeting the required MRQ. This was attributed to low sample concentration and the dilutions necessary to allow removal from the Shielded Cells for analysis. Neodymium values are upper limits. Neodymium unmet MRQ is of minimal impact since the concentrations present are above the detection limit.

- Rubidium, tantalum, and yttrium were flagged for not meeting the \%RSD. This was attributed to low sample concentration and the dilutions necessary to allow removal from the Shielded Cells for analysis. 


\section{WSRC-TR-2003-00210, REVISION 0 SRT-RPP-2003-00091, REVISION 0}

- ${ }^{133}$ Cs was flagged for the blank exceeding $5 \%$ of the sample concentration and not meeting the required \%RSD. This is attributed to contamination in the cells.

- Cerium was flagged for the blank exceeding $5 \%$ of the sample concentration.

- ${ }^{126} \mathrm{Sb} /{ }^{126} \mathrm{Sn},{ }^{152} \mathrm{Eu}$, and ${ }^{125} \mathrm{Sb}$ were flagged for not meeting the required MRQ. This was attributed to low sample concentration and the dilutions necessary to allow removal from the Shielded Cells for analysis.

- ${ }^{79}$ Se was flagged for not meeting the required MRQ. This was attributed to low sample concentration and the dilutions necessary to allow removal from the Shielded Cells for analysis. Higher energy beta was observed in the samples' ${ }^{79}$ Se spectra, therefore those results were caveated as upper limits.

- ${ }^{241}$ Am was flagged for not meeting the required \%RSD. ${ }^{244} \mathrm{Cm}$ was flagged for the blank exceeding $5 \%$ of the sample concentration and not meeting the required $\%$ RSD. ${ }^{242} \mathrm{Cm}$ was flagged for not meeting the required MRQ and \%RSD. A potential positive bias for the ${ }^{242} \mathrm{Cm}$ may exist if any ${ }^{252} \mathrm{Cf}$ is present in the samples. The blank sample generated in the cells showed significant ${ }^{244} \mathrm{Cm}$ contamination.

- $\quad{ }^{59} \mathrm{Ni}$ was flagged for not meeting the required MRQ and \%RSD. This was attributed to low sample concentration and the dilutions necessary to allow removal from the Shielded Cells for analysis.

- Gross alpha was flagged for not meeting the required \%RSD. Prior to the analyses, ${ }^{137} \mathrm{Cs}$ was removed from aliquots of the samples in order to reduce bias effects caused by large beta/alpha ratios. This was accomplished using Bio-Rad AMP1 resin. Following the Cs removal process, aliquots of the Cs-stripped samples were mounted on stainless steel counting planchets and analyzed for alpha activity using a gas-flow proportional counter. Results are background subtracted. The analysis was carried out in quadrature to illustrate the consistency within measurements for each given sample. Average results were provided. The $\%$ RSD was outside of the requested range. However, results of the four individual analyses used for each single sample all had \%RSD values of $<11.4 \%$. This indicates inconsistencies between samples and that the solids are somewhat heterogeneous..

- ${ }^{3} \mathrm{H}$ was flagged for not meeting the required MRQ and percent recovery of the LCS. This was attributed to low sample concentration and the dilutions necessary to allow removal from the Shielded Cells for analysis.

- $\quad{ }^{137}$ Cs concentration measured by gamma spectroscopy and ICP-MS show a difference of approximately $78 \%$. The values for ${ }^{135} \mathrm{Cs}$ and ${ }^{137} \mathrm{Cs}$ from the ICP-MS are upper limits and have a high bias due to the significant $\mathrm{Ba}$ concentration in the solids and should not be considered reliable. The results for mass 133 may be biased high also based upon the presence of a significant interference or contamination in the blank and glass standard.

- ${ }^{90} \mathrm{Sr}$ was flagged for not meeting the required \%RSD.

- ${ }^{238} \mathrm{Pu}$ and ${ }^{239 / 240} \mathrm{Pu}$ were flagged for the blank exceeding $5 \%$ of the sample concentration and not meeting the required MRQ and \%RSD. ${ }^{238} \mathrm{Pu}$ was flagged for not meeting the required $\%$ RSD. This was attributed to the dilutions necessary to allow removal from the Shielded Cells for analysis and contamination in the cells. 


\section{WSRC-TR-2003-00210, REVISION 0 SRT-RPP-2003-00091, REVISION 0}

- ${ }^{14} \mathrm{C}$ was flagged for not meeting the required MRQ and percent recovery of the LCS. These solids were so high in activity that they couldn't be run through the routine ${ }^{14} \mathrm{C}$ method, which was adjusted to enhance the separation of ${ }^{14} \mathrm{C}$ beta from the other activity. The provided sub-samples were washed from their respective centrifuge tubes with dilute caustic; the wash solution was wet-ashed with a sodium persulfate/silver nitrate oxidation in conjunction with concentrated sulfuric acid. The carbon dioxide emitted was absorbed with $3 \mathrm{M} \mathrm{NaOH}$ over a period of several days. The $3 \mathrm{M} \mathrm{NaOH}$ was then acidified, liberating the carbon dioxide, which was re-absorbed with Packard Instruments Carbosorb E over a period of several days. The Carbosorb E was then slurried into Ultima Gold $\mathrm{AB}$, and analyzed by liquid scintillation analysis for ${ }^{14} \mathrm{C}$. A laboratory control blank solution, spiked with a ${ }^{14} \mathrm{C}$ standard, was run in duplicate, in parallel with the samples to determine ${ }^{14} \mathrm{C}$ recoveries, the average of which were applied to the sample ${ }^{14} \mathrm{C}$ LSC results to quantify the ${ }^{14} \mathrm{C}$ concentrations in the samples. One set of AN-107 samples was spiked with ${ }^{14} \mathrm{C}$ (again in duplicate) and run through the process to serve as the matrix spike. A second laboratory control blank solution, spiked with a ${ }^{14} \mathrm{C}$ standard, was run through the process in duplicate to serve as the LCS sample.

\subsubsection{Discussion of Table 6-7, Composition of the As-Received 241-AN-107 Solids Aqua Regia Prep}

- All analytes analyzed by ICP-AES were flagged for quality control. This is attributed to low sample concentration and dilutions necessary to allow removal from the Shielded Cells for analysis and to the solid/liquid separation method required by the test specification. Many of what are generally thought of as solids associated analytes (e.g., $\mathrm{Mn}, \mathrm{Fe}, \mathrm{Ni}, \mathrm{Pb}, \mathrm{Zn}$ ) are as high or higher in the supernate than in the solids for AN-107 because of the complexants in the tank.

- Magnesium, Silver, Barium, Lithium, Titanium, and Vanadium were flagged for not meeting the required MRQ. Cd and S were flagged for not meeting the \%RSD. Ca and Sr were flagged for the blank exceeding $5 \%$ of the sample concentration. Copper was flagged for the blank exceeding 5\% of the sample concentration, being less than $10 \mathrm{x}$ the detection limit, and not meeting the required MRQ. The following were flagged for being less than 10x the detection limit and not meeting the required MRQ: Be, Si, U, and Zr. Manganese, Nickel, and Lead were flagged for not meeting the required MRQ and $\%$ RSD. Aluminum and Phosphorus were flagged for the blank exceeding 5\% of the sample concentration and not meeting the required MRQ and \%RSD. Chromium, Iron, and Zinc were flagged for the blank exceeding $5 \%$ of the sample concentration and not meeting the $\%$ RSD.

- Aluminum, phosphorus, lead, manganese, and nickel unmet MRQs are of minimal impact since the concentrations present are well above the detection limit.

- Potassium was flagged for the blank exceeding 5\% of the sample concentration and not meeting the \%RSD. Sodium was flagged for not meeting the required \%RSD and Selenium was flagged for not meeting the required MRQ. 


\section{WSRC-TR-2003-00210, REVISION 0 SRT-RPP-2003-00091, REVISION 0}

- ${ }^{233} \mathrm{U},{ }^{234} \mathrm{U}, \mathrm{Se}, \mathrm{Te}, \mathrm{Pr}, \mathrm{Ta}, \mathrm{Pt}$, and Tl were flagged for not meeting the required MRQ. This is attributed to low sample concentration and dilutions necessary to allow removal from the Shielded Cells for analysis.

- ${ }^{238} \mathrm{U}$, total uranium, ${ }^{133} \mathrm{Cs}$, and Ce were flagged for not meeting the required \%RSD. This is attributed to dilutions necessary to allow removal from the Shielded Cells for analysis.

- Thorium, Cobalt, Ruthenium, Molybdenum, Lead, Rhodium, Plutonium, Yttrium, and Neodymium were flagged for not meeting the required MRQ and \%RSD. This is attributed to dilutions necessary to allow removal from the Shielded Cells for analysis and low concentrations in the sample.

- Thorium, ruthenium, molybdenum, rubidium, rhodium, yttrium, neodymium, and praseodymium unmet MRQs are of minimal impact since the concentrations are well above the detection limit.

- $\quad{ }^{236} \mathrm{U}$ and ${ }^{237} \mathrm{~Np}$ were flagged for values being less than $10 \mathrm{x}$ the detection limit and not meeting the required \%RSD. This is attributed to low concentrations in the sample.

- ${ }^{235} \mathrm{U}$, Vanadium, ${ }^{135} \mathrm{Cs}$, and ${ }^{137} \mathrm{Cs}$ were flagged for the blank exceeding $5 \%$ of the sample concentration and not meeting the required \%RSD. This is attributed sample contamination.

- Arsenic, Rubidium, Antimony, and Barium were flagged for not meeting the required MRQ and \%RSD and the blank exceeding $5 \%$ of the sample concentration.

- Tungsten was flagged for not meeting the percent recovery of the MS and \%RSD. This is attributed to contamination within the system.

- Bismuth was flagged for not meeting the required MRQ and the blank exceeding 5\% of the sample concentration.

- $\quad{ }^{137} \mathrm{Cs}$ was flagged for not meeting the required \%RSD. The third replicate appeared higher than the other two replicates. The third replicate was reanalyzed and the second analysis confirmed the first analysis. This trend of the third replicate appearing higher than the other two replicates was also noted in the $\mathrm{Sr}-90$ results.

- $\quad{ }^{137} \mathrm{Cs}$ concentration measured by gamma spectroscopy and ICP-MS show a difference of $\sim 50 \%$. The values for ${ }^{135} \mathrm{Cs}$ and ${ }^{137} \mathrm{Cs}$ from the ICP-MS have a high bias due to the stable Ba concentration in the solids and should not be considered reliable. The results for mass 133 may be biased high also due to the presence of an interference or contamination in the glass standard.

- Tritium was flagged for not meeting the required MRQ. The third replicate did not undergo a successful separation. This was evident in the spectrum of the distillate, therefore the data is not reported. 
- The gross alpha was flagged for the blank exceeding 5\% of the sample concentration and not meeting the $\%$ RSD. ${ }^{137} \mathrm{Cs}$ was removed from aliquots of the samples in order to reduce bias effects caused by large beta/alpha ratios. This was accomplished using BioRad AMP1 resin. Following the Cs removal process, aliquots of the Cs-stripped samples were mounted on stainless steel counting planchets and analyzed for alpha activity using a gas-flow proportional counter. Results are background subtracted. The analysis was carried out in quadrature to illustrate the consistency between the measurement for each given sample. Average results are provided. The $\%$ RSD was $20 \%$, slightly outside of the requested range. However, results of the 4 individual analyses used for each single sample all had $\%$ RSD values of $<10 \%$. This indicates inconsistencies with in the samples. The blank sample contained more than $10 \%$ of the activity observed in the samples indicating contamination.

- ${ }^{90} \mathrm{Sr}$ was flagged for not meeting the required MRQ and \%RSD. The MRQ is not critical in this case because the concentration is well above the method detection limit.

- ${ }^{241} \mathrm{Am},{ }^{243} \mathrm{Am},{ }^{242} \mathrm{Cm}$, and ${ }^{244} \mathrm{Cm}$ all were flagged for the blank exceeding $5 \%$ of the sample concentration and not meeting the \%RSD. ${ }^{242} \mathrm{Cm}$ was flagged for not meeting the required MRQ as well. A potential positive bias for the ${ }^{242} \mathrm{Cm}$ may exist if any ${ }^{252} \mathrm{Cf}$ is present in the samples. The blank sample generated in the cells showed significant contamination in the blank and glass standard.

- ${ }^{238} \mathrm{Pu}$ and ${ }^{239 / 240} \mathrm{Pu}$ were flagged for the blank exceeding 5\% of the sample concentration and not meeting the required MRQ and \%RSD. ${ }^{238} \mathrm{Pu}$ was flagged for not meeting the required \%RSD. Comparable amounts of $\mathrm{Pu}$ were present in the blank and the samples. Each sample was subjected to two different spike steps. Results from both experiments were averaged and each lab replicate agreed within 1 sigma. These QC failures were attributed to low concentrations present in the sample and the dilutions necessary to allow removal from the Shielded Cells for analysis.

- ${ }^{129}$ I was flagged for not meeting the required MRQ. This was attributed to low concentrations present in the sample and the dilutions necessary to allow removal from the Shielded Cells for analysis.

\subsubsection{Discussion of Table 6-8, Composition of the As-Received 241-AN-107 Solids Water Leach Prep}

- Fluoride was flagged for not meeting the MRQ. This failure was attributed to low concentrations present in the sample.

- The blank for the analytes appear high because the sample dilution factor is applied to the blank.

\subsection{DATA TABLES}

Data are presented in this section in Table 6-1 through Table 6-8. 
WSRC-TR-2003-00210, REVISION 0

SRT-RPP-2003-00091, REVISION 0

Table 6-1. Abbreviations for Analytical Methods in Tables 6-5 through 6-8

\begin{tabular}{|l|c|c|}
\hline Analytical Method & Abbreviation in Tables & ADS Procedure No. \\
\hline Ion Chromatography & IC & ADS-2306 \\
\hline Ammonia Purge and Trap & PT & ADS-2306 \\
\hline Titration & T & ADS-1206, Rev. 1 \\
\hline ICP-AES & IE & ADS-1564 \\
\hline ICP-MS & IM & ADS-1543 \\
\hline AA & AA & ADS-1554, Rev. 3 \\
\hline Calc. By Difference & Diff & ADS-1206, Rev. 1 \\
\hline Acidification & A & ADS-2236, Rev. 4 \\
\hline Chemchek (Uranium) & CC & ADS-2420 \\
\hline Gamma Spec. & GS & ADS-2420 \\
\hline Separation/Gamma Spec. & SG & ADS-2453 \\
\hline Separation/Alpha Spec. & SA & ADS-2449 \\
\hline Separation/Liquid Scintillation & & ADS-2447 \\
& SL & ADS-2444 \\
\hline Alpha Counting & & ADS-2402 \\
\hline HPLC & AC & ADS-2660 \\
\hline Gross Alpha and Beta & HL & ADS-2424 \\
\hline Tc-99 & & ADS-2445 \\
\hline GC-MS & & ADS-2661 \\
\hline
\end{tabular}


WSRC-TR-2003-00210, REVISION 0

SRT-RPP-2003-00091, REVISION 0

Table 6-2. Physical Properties of the As-Received 241-AN-107 Sample

\begin{tabular}{|l|c|c|c|c|c|c|c|}
\hline Property & Units & $\begin{array}{c}\text { 1st } \\
\text { Replicate }\end{array}$ & $\begin{array}{c}\mathbf{2}^{\text {nd }} \\
\text { Replicate }\end{array}$ & $\begin{array}{c}\text { 3rd } \\
\text { Replicate }\end{array}$ & Average & \%RSD & $\begin{array}{c}\text { QC } \\
\text { Flag }\end{array}$ \\
\hline Slurry Density & $\mathrm{g} / \mathrm{mL}$ & 1.42 & 1.41 & 1.42 & 1.42 & 0.41 & - \\
\hline Filtered Supernate Density & $\mathrm{g} / \mathrm{mL}$ & 1.414 & 1.415 & 1.415 & 1.415 & 0.04 & - \\
\hline Vol \% Centrifuged Solids & $\mathrm{Vol} \%$ & 8 & 10 & 6 & 8 & 25 & $\mathrm{U}_{\mathrm{R}}$ \\
\hline Wt. \% Centrifuged Solids & $\mathrm{Wt} \%$ & 7.18 & 6.51 & 6.95 & 6.88 & 5 & - \\
\hline $\mathrm{Wt} \%$ Total Dried Solids & $\mathrm{Wt} \%$ & 49.65 & 49.45 & 49.4 & 49.50 & 0.27 & - \\
\hline $\mathrm{Wt} \%$ Dissolved Solids & $\mathrm{Wt} \%$ & 49.49 & 48.99 & 49.29 & 49.25 & 0.51 & - \\
\hline Wt\% Insoluble solids & $\mathrm{Wt} \%$ & 0.323 & 0.911 & 0.215 & 0.483 & 78 & $\mathrm{U}_{\mathrm{R}}$ \\
\hline Heat Capacity & $\mathrm{J} / \mathrm{g}-{ }^{\circ} \mathrm{C}$ & 3.39 & 3.39 & 3.39 & 3.39 & 0.08 & - \\
\hline
\end{tabular}


WSRC-TR-2003-00210, REVISION 0

SRT-RPP-2003-00091, REVISION 0

Table 6-3. Rheology Measurements at $25^{\circ} \mathrm{C}$

\begin{tabular}{|l|c|c|c|c|c|}
\hline Replicates & $\begin{array}{c}\text { Sweep } \\
\text { Direction }\end{array}$ & $\begin{array}{c}\text { Viscosity } \\
\mathbf{c P}\end{array}$ & $\begin{array}{c}\text { Offset } \\
\mathbf{P a}\end{array}$ & $\mathbf{R}^{\mathbf{2}}$ & $\begin{array}{c}\text { Range } \\
\mathbf{s e c}^{-1}\end{array}$ \\
\hline Replicate1 & $\mathrm{Up}$ & 9.76 & 1.11 & 0.9972 & $0-1000$ \\
\hline Replicate2 & & 9.24 & 1.67 & 0.9966 & $0-1000$ \\
\hline Replicate3 & & 9.27 & 1.71 & 0.9973 & $0-1000$ \\
\hline Replicate1 & Down & 9.18 & 1.48 & 0.9977 & $0-1000$ \\
\hline Replicate2 & & 9.37 & 1.43 & 0.9976 & $0-1000$ \\
\hline Replicate3 & & 9.34 & 1.48 & 0.9986 & $0-1000$ \\
\hline & Average & 9.36 & 1.48 & & \\
\cline { 2 - 4 } & \%RSD & 2.23 & 14.52 & & \\
\hline
\end{tabular}

Table 6-4. Rheology Measurements at $40{ }^{\circ} \mathrm{C}$

\begin{tabular}{|l|c|c|c|c|c|}
\hline Replicates & $\begin{array}{c}\text { Sweep } \\
\text { Direction }\end{array}$ & $\begin{array}{c}\text { Viscosity } \\
\mathbf{c P}\end{array}$ & $\begin{array}{c}\text { Offset } \\
\mathbf{P a}\end{array}$ & $\mathbf{R}^{\mathbf{2}}$ & $\begin{array}{c}\text { Range } \\
\mathbf{s e c}^{-1}\end{array}$ \\
\hline Replicate1 & Up & 5.87 & 1.07 & 0.9934 & $0-850$ \\
\hline Replicate2 & & 5.89 & 1.17 & 0.9925 & $0-850$ \\
\hline Replicate3 & & 5.89 & 1.20 & 0.9951 & $0-850$ \\
\hline Replicate1 & Down & 5.85 & 0.96 & 0.9934 & $0-850$ \\
\hline Replicate2 & & 5.85 & 1.01 & 0.9925 & $0-850$ \\
\hline Replicate3 & & 5.86 & 1.00 & 0.9951 & $0-850$ \\
\hline & Average & 5.87 & 1.07 & & \\
\cline { 2 - 4 } & \%RSD & 0.28 & 9.27 & & \\
\hline
\end{tabular}


WSRC-TR-2003-00210, REVISION 0

SRT-RPP-2003-00091, REVISION 0

Table 6-5. Composition of the As-Received 241-AN-107 Filtered Supernate

\begin{tabular}{|c|c|c|c|c|c|c|c|c|c|}
\hline Analyte & $\begin{array}{c}1^{\text {st }} \\
\text { Replicate } \\
(\mathbf{m g} / \mathrm{L}) \\
\end{array}$ & $\begin{array}{c}2^{\text {nd }} \\
\text { Replicate } \\
(\mathrm{mg} / \mathrm{L})\end{array}$ & $\begin{array}{c}3^{\text {rd }} \\
\text { Replicate } \\
(\mathrm{mg} / \mathrm{L})\end{array}$ & $\begin{array}{c}\text { Average } \\
(\mathrm{mg} / \mathrm{L})\end{array}$ & $\%$ RSD & $\begin{array}{c}\text { Blank } \\
(\mathrm{mg} / \mathrm{L})\end{array}$ & $\begin{array}{c}\text { LCS \% } \\
\text { Recovery }\end{array}$ & $\begin{array}{c}\text { MS \% } \\
\text { Recovery }\end{array}$ & $\begin{array}{c}\text { QC } \\
\text { Flag }\end{array}$ \\
\hline $\mathrm{Ag}^{*} \quad$ (IE) & 2 & $<2.27$ & 2 & 2 & 4 & $<0.880$ & 101 & NA & $\mathrm{U}_{\mathrm{E}} \mathrm{U}_{\mathrm{M}}$ \\
\hline Al (IE) & 314 & 295 & 308 & 306 & 3 & $<6.27$ & 100 & NA & - \\
\hline $\mathrm{B}^{*} \quad$ (IE) & 13 & $<7.95$ & 12 & 13 & 4 & $<3.08$ & 94 & NA & $\mathrm{U}_{\mathrm{E}}$ \\
\hline $\mathrm{Ba} \quad$ (IE) & 10 & 9 & 10 & 10 & 3 & $<2.09$ & 103 & 118 & $\mathrm{U}_{\mathrm{E}}$ \\
\hline Be (IE) & $<0.156$ & $<0.284$ & $<0.156$ & $<0.199$ & - & $<0.110$ & 100 & NA & $\mathrm{U}_{\mathrm{E}}$ \\
\hline $\begin{array}{ll}\mathrm{Ca} & \text { (IE) }\end{array}$ & 565 & 577 & 557 & 566 & 2 & $<2.53$ & 102 & NA & - \\
\hline $\mathrm{Cd}$ (IE) & 73 & 72 & 71 & 72 & 1 & $<0.462$ & 102 & 110 & - \\
\hline Cr (IE) & 195 & 189 & 190 & 191 & 2 & $<0.660$ & 102 & 109 & - \\
\hline $\mathrm{Cu}$ (IE) & 38 & 35 & 41 & 38 & 8 & 1.02 & 99 & NA & - \\
\hline Fe (IE) & 1889 & 1860 & 1846 & 1865 & 1 & 2.13 & 102 & 105 & - \\
\hline $\mathrm{Li}$ (IE) & $<6.72$ & $<12.2$ & $<6.72$ & $<8.55$ & - & $<4.73$ & 96 & NA & $\mathrm{U}_{\mathrm{E}} \mathrm{U}_{\mathrm{M}}$ \\
\hline $\mathrm{Mg} \sim(\mathrm{IE})$ & 0.879 & $<1.51$ & $<0.828$ & 0.879 & - & $<0.583$ & 103 & NA & $\mathrm{U}_{\mathrm{E}} \mathrm{U}_{\mathrm{M}}$ \\
\hline Mn $\quad$ (IE) & 673 & 659 & 659 & 664 & 1 & $<0.088$ & 102 & NA & - \\
\hline $\mathrm{Na} \quad$ (IE) & 210,160 & 207,320 & 205,900 & 207,793 & 1 & 36.3 & 98 & 95 & - \\
\hline $\mathrm{Ni} \quad$ (IE) & 589 & 582 & 572 & 581 & 1 & $<1.49$ & 103 & 99 & - \\
\hline $\begin{array}{ll}\mathrm{P} & \text { (IE) } \\
\end{array}$ & 558 & 558 & 565 & 560 & 1 & $<7.59$ & 103 & NA & $\mathrm{U}_{\mathrm{M}}$ \\
\hline $\mathrm{Pb} \quad$ (IE) & 471 & 447 & 460 & 460 & 3 & $<3.51$ & 102 & NA & - \\
\hline S $\quad$ (IE) & 3877 & 3664 & 3749 & 3763 & 3 & $<15.1$ & 100 & NA & - \\
\hline Si $\quad$ (IE) & 16 & 15 & 14 & 15 & 6 & $<1.84$ & 102 & NA & $\overline{U_{E}}$ \\
\hline $\mathrm{Sr} \quad$ (IE) & 120 & 124 & 118 & 121 & 3 & $<0.836$ & 101 & NA & - \\
\hline Ti (IE) & $<1.20$ & $<2.19$ & $<1.20$ & $<1.53$ & - & $<0.847$ & N/A & NA & $\mathrm{U}_{\mathrm{E}}$ \\
\hline U (IE) & 172 & 168 & 169 & 169 & 1 & $<25$ & 98 & NA & $\mathrm{U}_{\mathrm{E}} \mathrm{U}_{\mathrm{M}}$ \\
\hline V (IE) & 0.581 & 0.859 & 0.914 & 0.785 & 23 & $<0.220$ & 101 & NA & $\mathrm{U}_{\mathrm{R}} \mathrm{U}_{\mathrm{E}} \mathrm{U}_{\mathrm{M}}$ \\
\hline $\mathrm{Zn} \quad$ (IE) & 30 & 27 & 31 & 29 & 7 & $<0.352$ & 102 & NA & - \\
\hline As (AA) & $<0.9372$ & $<0.937$ & $<0.937$ & $<0.937$ & - & $<0.05$ & 91 & 116 & - \\
\hline K $\quad$ (AA) & 1541 & 1555 & 1571 & 1556 & 1 & $<5.22$ & 100 & 97 & - \\
\hline $\begin{array}{ll}\mathrm{Na} & \text { (AA) }\end{array}$ & 192,166 & 185,149 & 187,647 & 188,321 & 2 & $<280$ & 96 & 98 & - \\
\hline Se $\quad(\mathrm{AA})$ & $<0.937$ & $<0.937$ & $<0.937$ & $<0.937$ & - & $<0.05$ & 110 & 98 & - \\
\hline $\mathrm{Hg}$ (AA) & $<2.29$ & $<2.30$ & $<2.27$ & $<2.29$ & - & $<0.11$ & 104 & 107 & - \\
\hline Th (IM) & 16 & 18 & 19 & 18 & 7 & 0.02 & 99 & 110 & - \\
\hline${ }^{234} \mathrm{U} \quad$ (IM) & $<0.033$ & $<0.033$ & $<0.033$ & $<0.0327$ & - & $<0.023$ & NA & NA & - \\
\hline${ }^{235} \mathrm{U}$ (IM) & 0.83 & 0.71 & 0.81 & 0.78 & 8 & $<0.023$ & 97 & 118 & - \\
\hline${ }^{236} \mathrm{U} \sim(\mathrm{IM})$ & 0.04 & $<0.033$ & $<0.033$ & 0.04 & - & $<0.023$ & NA & NA & - \\
\hline \begin{tabular}{|l}
${ }^{237} \mathrm{~Np}$ \\
\end{tabular} & 0.11 & 0.08 & 0.08 & 0.09 & 21 & $<0.023$ & $\mathrm{NA}$ & NA & $\mathrm{U}_{\mathrm{R}}$ \\
\hline $\begin{array}{ll}{ }^{238} \mathrm{U} & \text { (IM) }\end{array}$ & 127 & 126 & 123 & 125 & 2 & 0.49 & 97 & 98 & - \\
\hline${ }^{239} \mathrm{Pu} \quad$ (IM) & 0.74 & 0.70 & 0.69 & 0.71 & 4 & $<0.023$ & NA & NA & - \\
\hline${ }^{240} \mathrm{Pu} \quad$ (IM) & 0.06 & 0.05 & 0.05 & 0.05 & 8 & $<0.023$ & $\mathrm{NA}$ & NA & - \\
\hline Total U (IM) & 128 & 127 & 124 & 126 & 2 & 0.49 & $\mathrm{NA}$ & NA & - \\
\hline $\mathrm{Rb} \quad$ (IM) & 7 & 8 & 8 & 8 & 2 & 0.004 & 105 & 113 & - \\
\hline
\end{tabular}


WSRC-TR-2003-00210, REVISION 0

SRT-RPP-2003-00091, REVISION 0

Table 6-5. Composition of the As-Received 241-AN-107 Filtered Supernate (page 2 of 3)

\begin{tabular}{|c|c|c|c|c|c|c|c|c|c|}
\hline Analyte & $\begin{array}{c}1^{\text {st }} \\
\text { Replicate } \\
(\mathrm{mg} / \mathrm{L})\end{array}$ & $\begin{array}{c}2^{\text {nd }} \\
\text { Replicate } \\
(\mathrm{mg} / \mathrm{L}) \\
\end{array}$ & $\begin{array}{c}3^{\text {rd }} \\
\text { Replicate } \\
(\mathrm{mg} / \mathrm{L}) \\
\end{array}$ & $\begin{array}{c}\text { Average } \\
(\mathrm{mg} / \mathrm{L})\end{array}$ & $\%$ RSD & $\begin{array}{c}\text { Blank } \\
(\mathrm{mg} / \mathrm{L})\end{array}$ & $\begin{array}{c}\text { LCS \% } \\
\text { Recovery }\end{array}$ & $\begin{array}{c}\text { MS \% } \\
\text { Recovery }\end{array}$ & $\begin{array}{c}\text { QC } \\
\text { Flag } \\
\end{array}$ \\
\hline${ }^{133} \mathrm{Cs} \quad$ (IM) & 11 & 11 & 11 & 11 & 1 & 0.01 & 104 & 111 & - \\
\hline${ }^{135} \mathrm{Cs} \quad$ (IM) & 2 & 2 & 2 & 2 & 1 & 0.13 & 104 & NA & - \\
\hline${ }^{137} \mathrm{Cs} \quad$ (IM) & 5 & 5 & 5 & 5 & 1 & 0.25 & 98 & NA & - \\
\hline La (IM) & 35 & 35 & 36 & 35 & 2 & 0.01 & 101 & NA & - \\
\hline \begin{tabular}{|ll}
$\mathrm{W}$ & (IM) \\
\end{tabular} & 114 & 214 & 166 & 165 & 30 & 0.024 & 113 & 167 & $\mathrm{U}_{\mathrm{S}} \mathrm{U}_{\mathrm{R}}$ \\
\hline HEDTA (HL) & 1111 & 935 & 1321 & 1123 & 17 & $<10$ & 95 & 92 & - \\
\hline EDTA (HL) & 3607 & 3403 & 3870 & 3627 & 6 & $<10$ & 105 & 93 & - \\
\hline IDA $(\mathrm{GM})$ & 3783 & 4344 & 4034 & 4054 & 7 & $<25$ & 109 & 107 & - \\
\hline TIC (A) & 27500 & 20800 & 31500 & 26600 & 20 & 0 & 99.6 & 102 & $\mathrm{U}_{\mathrm{R}}$ \\
\hline TOC (Diff) & 27200 & 34500 & 38200 & 33300 & 17 & 9.44 & 101 & 99 & $\mathrm{U}_{\mathrm{R}}$ \\
\hline${ }^{133} \mathrm{Cs} \quad$ (IM) & 11 & 11 & 11 & 11 & 1 & 0.01 & 104 & 111 & - \\
\hline Total Base (T) & $1.32 \mathrm{M}$ & $1.32 \mathrm{M}$ & $1.32 \mathrm{M}$ & $1.32 \mathrm{M}$ & 0 & $<0.02 \mathrm{M}$ & 96 & 99 & $\mathrm{U}_{\mathrm{M}}$ \\
\hline Free $\mathrm{OH} \quad(\mathrm{T})$ & $<340$ & $<340$ & - & $<340$ & - & - & 103 & 98.6 & $\mathrm{U}_{\mathrm{M}}$ \\
\hline $\mathrm{F} \quad(\mathrm{IC})$ & 3440 & 3047 & 3471 & 3319 & 7 & $<20$ & 105 & 115 & - \\
\hline $\mathrm{CHO}_{2} \quad$ (IC) & 11503 & 10332 & 11503 & 11112 & 6 & $<100$ & 102 & 113 & - \\
\hline $\mathrm{Cl}$ (IC) & 1440 & 1275 & 1461 & 1392 & 7 & $<20$ & 99 & 103 & - \\
\hline $\mathrm{NO}_{2} \quad(\mathrm{IC})$ & 62694 & 56373 & 63212 & 60760 & 6 & $<100$ & 105 & 105 & - \\
\hline $\mathrm{NO}_{3} \quad(\mathrm{IC})$ & 232123 & 207253 & 235232 & 224869 & 7 & $<100$ & 100 & 115 & - \\
\hline $\mathrm{PO}_{4} \quad(\mathrm{IC})$ & 984 & 881 & 974 & 946 & 6 & $<100$ & 98 & 97 & - \\
\hline $\mathrm{SO}_{4} \quad(\mathrm{IC})$ & 8715 & 7668 & 9057 & 8480 & 9 & $<50$ & 99 & 108 & - \\
\hline $\mathrm{C}_{2} \mathrm{O}_{4} \quad$ (IC) & 694 & 591 & 705 & 663 & 10 & $<100$ & 100 & 105 & - \\
\hline $\mathrm{NH}_{3} \quad(\mathrm{PT})$ & 404 & 425 & 415 & 415 & 3 & $<10$ & 109 & 116 & - \\
\hline Citrate (IC) & 12124 & 12435 & 12021 & 12193 & 2 & $<10$ & 94 & 95 & - \\
\hline $\begin{array}{l}\text { Glycolate } \\
\text { (IC) }\end{array}$ & 24767 & 24870 & 24767 & 24801 & 0.2 & $<10$ & 86 & 125 & - \\
\hline Acetate (IC) & 1534 & 1420 & 1368 & 1440 & 6 & $<10$ & 87 & 67 & $\mathrm{U}_{\mathrm{S}}$ \\
\hline $\begin{array}{l}\text { Carbonate } \\
\text { (IC) }\end{array}$ & 20933 & 19585 & 12953 & 17824 & 24 & $<50$ & 155 & 174 & $\mathrm{U}_{\mathrm{R}} \mathrm{U}_{\mathrm{S}} \mathrm{U}_{\mathrm{L}}$ \\
\hline $\begin{array}{l}\text { One V } \\
\text { QC Flag } \\
\mathrm{U}_{\mathrm{B}}-\text { bla } \\
\mathrm{U}_{\mathrm{E}}-\text { valu } \\
\mathrm{N} / \mathrm{M}-\mathrm{no}\end{array}$ & $\begin{array}{l}\text { none - meets } \\
\text { exceeds } 5 \% \\
\text { less than } 10 x \\
\text { neasured }\end{array}$ & $\begin{array}{l}\text { all QC } \\
\text { f sample con } \\
\text { the MDL }\end{array}$ & ration & $\begin{array}{l}U_{R}-\text { fails } \% R S \\
U_{L} \text { - fails } \% R \\
N D \text { - not detec }\end{array}$ & $\begin{array}{l}\text { D criteria } \\
\text { ecovery of } L \\
\text { ted }\end{array}$ & $\begin{array}{l}U_{M}- \\
U_{S}-1 \\
N A-\end{array}$ & $\begin{array}{l}\text { fails minimum } \\
\text { ails \% Recover } \\
\text { not applicable }\end{array}$ & $\begin{array}{l}\text { MRQ criteria } \\
y \text { of MS }\end{array}$ & \\
\hline
\end{tabular}


WSRC-TR-2003-00210, REVISION 0

SRT-RPP-2003-00091, REVISION 0

Table 6-5. Composition of the As-Received 241-AN-107 Filtered Supernate (page 3 of 3 )

\begin{tabular}{|c|c|c|c|c|c|c|c|c|c|}
\hline Analyte & $\begin{array}{c}1^{\text {st }} \\
\text { Replicate } \\
\text { (mCi/L) }\end{array}$ & $\begin{array}{c}2^{\text {nd }} \\
\text { Replicate } \\
\text { (mCi/L) }\end{array}$ & $\begin{array}{c}3^{\text {rd }} \\
\text { Replicate } \\
\text { (mCi/L) }\end{array}$ & $\begin{array}{l}\text { Average } \\
(\mathrm{mCi} / \mathrm{L})\end{array}$ & $\%$ RSD & $\begin{array}{c}\text { Blank } \\
(\mathbf{m C i} / \mathbf{L})\end{array}$ & $\begin{array}{c}\text { LCS \% } \\
\text { Recovery }\end{array}$ & $\begin{array}{c}\text { MS \% } \\
\text { Recovery }\end{array}$ & $\begin{array}{c}\text { QC } \\
\text { Flag }\end{array}$ \\
\hline $\begin{array}{l}\text { Gross Beta } \\
\text { (SL) }\end{array}$ & $6.03 E+02$ & $5.88 \mathrm{E}+02$ & $5.85 \mathrm{E}+02$ & $5.92 \mathrm{E}+02$ & 1.61 & $<2.20 \mathrm{E}-02$ & 100.77 & 94.01 & - \\
\hline${ }^{238} \mathrm{Pu} \quad(\mathrm{SA})$ & $1.21 \mathrm{E}-02$ & $1.34 \mathrm{E}-02$ & $1.25 \mathrm{E}-02$ & $1.26 \mathrm{E}-02$ & 5.19 & $2.98 \mathrm{E}-04$ & NA & NA & - \\
\hline $2^{239 / 240} \mathrm{Pu} \quad$ (SA) & $4.54 \mathrm{E}-02$ & $5.67 \mathrm{E}-02$ & $4.75 \mathrm{E}-02$ & $4.99 \mathrm{E}-02$ & 12.12 & $2.82 \mathrm{E}-05$ & NA & NA & - \\
\hline${ }^{241} \mathrm{Pu} \quad(\mathrm{SA})$ & $8.38 \mathrm{E}-02$ & $9.34 \mathrm{E}-02$ & $8.25 \mathrm{E}-02$ & $8.66 \mathrm{E}-02$ & 6.87 & $1.05 \mathrm{E}-03$ & NA & NA & - \\
\hline${ }^{137} \mathrm{Cs} \quad$ (GS) & $3.36 \mathrm{E}+02$ & $3.31 \mathrm{E}+02$ & $3.37 \mathrm{E}+02$ & $3.35 \mathrm{E}+02$ & 0.90 & $<1.18 \mathrm{E}-02$ & $\overline{\mathrm{NA}}$ & $\overline{\mathrm{NA}}$ & - \\
\hline $\begin{array}{ll}{ }^{90} \mathrm{Sr} & (\mathrm{SL})\end{array}$ & $8.25 \mathrm{E}+01$ & $8.70 \mathrm{E}+01$ & $8.32 \mathrm{E}+01$ & $8.42 \mathrm{E}+01$ & 2.88 & $<1.93 \mathrm{E}-03$ & 90.61 & 164.32 & $\mathrm{U}_{\mathrm{S}}$ \\
\hline $\begin{array}{l}{ }^{99} \text { Tc Pertech. } \\
\text { (SL) }\end{array}$ & $<5.23 \mathrm{E}-02$ & $<4.73 \mathrm{E}-02$ & $<5.36 \mathrm{E}-02$ & $<5.11 \mathrm{E}-02$ & - & $<6.26 \mathrm{E}-06$ & $\overline{\mathrm{NA}}$ & NA & 5 \\
\hline $\begin{array}{l}{ }^{99} \mathrm{Tc} \text { (total) } \\
\text { (SL) }\end{array}$ & $1.02 \mathrm{E}-01$ & $1.02 \mathrm{E}-01$ & $1.07 \mathrm{E}-01$ & $1.04 \mathrm{E}-01$ & 2.69 & E-06 & $\overline{\mathrm{NA}}$ & $\overline{\text { NA }}$ & - \\
\hline $\begin{array}{ll}{ }^{59} \mathrm{Ni} & (\mathrm{SL}) \\
\end{array}$ & $2.11 \mathrm{E}-02$ & $2.82 \mathrm{E}-02$ & $2.48 \mathrm{E}-02$ & $2.47 \mathrm{E}-02$ & 14.29 & $<9.96 \mathrm{E}-06$ & NA & NA & - \\
\hline $\begin{array}{ll}{ }^{63} \mathrm{Ni} & \text { (SL) }\end{array}$ & $1.66 \mathrm{E}+00$ & $1.73 \mathrm{E}+00$ & $1.61 \mathrm{E}+00$ & $1.66 \mathrm{E}+00$ & 3.44 & $<1.59 \mathrm{E}-05$ & NA & NA & - \\
\hline${ }^{60} \mathrm{Co} \quad$ (GS) & $9.63 \mathrm{E}-02$ & $6.87 \mathrm{E}-02$ & $7.98 \mathrm{E}-02$ & $8.16 \mathrm{E}-02$ & 17.01 & $<1.60 \mathrm{E}-06$ & NA & NA & $\mathrm{U}_{\mathrm{R}}$ \\
\hline${ }^{126} \mathrm{Sb} /{ }^{126} \mathrm{Sn}(\mathrm{GS})$ & $9.01 \mathrm{E}-04$ & $5.73 \mathrm{E}-04$ & $7.10 \mathrm{E}-04$ & $7.28 \mathrm{E}-04$ & 22.63 & $<1.22 \mathrm{E}-06$ & $\overline{\mathrm{NA}}$ & $\overline{\mathrm{NA}}$ & $\mathrm{U}_{\mathrm{E}} \mathrm{U}_{\mathrm{M}} \mathrm{U}_{\mathrm{R}}$ \\
\hline${ }^{125} \mathrm{Sb} \quad$ (GS) & $3.06 \mathrm{E}-03$ & $1.74 \mathrm{E}-03$ & $2.48 \mathrm{E}-03$ & $2.42 \mathrm{E}-03$ & 27.36 & $<3.67 \mathrm{E}-06$ & NA & NA & $\mathrm{U}_{\mathrm{E}} \mathrm{U}_{\mathrm{R}}$ \\
\hline $\begin{array}{ll}{ }^{152} \mathrm{Eu} & \text { (GS) }\end{array}$ & $8.29 \mathrm{E}-03$ & $6.63 \mathrm{E}-03$ & $7.20 \mathrm{E}-03$ & $7.37 \mathrm{E}-03$ & 11.40 & $<1.08 \mathrm{E}-05$ & $\overline{\mathrm{NA}}$ & $\overline{\mathrm{NA}}$ & - \\
\hline${ }^{154} \mathrm{Eu} \quad$ (GS) & $5.11 \mathrm{E}-01$ & $3.64 \mathrm{E}-01$ & $4.25 \mathrm{E}-01$ & $4.33 \mathrm{E}-01$ & 17.00 & $4.13 \mathrm{E}-06$ & $\overline{\mathrm{NA}}$ & $\overline{\mathrm{NA}}$ & $\overline{U_{R}}$ \\
\hline${ }^{155} \mathrm{Eu} \quad(\mathrm{GS})$ & $3.02 \mathrm{E}-01$ & $2.07 \mathrm{E}-01$ & $2.47 \mathrm{E}-01$ & $2.52 \mathrm{E}-01$ & 19.04 & $<2.75 \mathrm{E}-06$ & NA & NA & $\mathrm{U}_{\mathrm{R}}$ \\
\hline${ }^{231} \mathrm{~Pa} \quad$ (GS) & $<1.37 \mathrm{E}-02$ & $<1.14 \mathrm{E}-02$ & $<1.23 \mathrm{E}-02$ & $<1.25 \mathrm{E}-02$ & 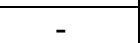 & $<4.21 \mathrm{E}-05$ & NA & NA & - \\
\hline${ }^{129} \mathrm{I} \quad(\mathrm{SG})$ & $2.31 \mathrm{E}-04$ & $9.15 \mathrm{E}-05$ & $1.25 \mathrm{E}-04$ & $1.49 \mathrm{E}-04$ & 48.81 & $1.87 \mathrm{E}-05$ & NA & NA & $\mathrm{U}_{\mathrm{R}}$ \\
\hline${ }^{14} \mathrm{C}^{*} \quad(\mathrm{SL})$ & $6.22 \mathrm{E}-04$ & $3.96 \mathrm{E}-04$ & $<1.07 \mathrm{E}-03$ & $6.97 \mathrm{E}-04$ & 49.42 & $<3.33 \mathrm{E}-05$ & 102.7 & 104.8 & $\mathrm{U}_{\mathrm{E}} \mathrm{U}_{\mathrm{M}} \mathrm{U}_{\mathrm{R}}$ \\
\hline${ }^{79} \mathrm{Se}$ (SL) & $<4.55 \mathrm{E}-03$ & $<6.49 \mathrm{E}-03$ & $<3.24 \mathrm{E}-03$ & $<4.76 \mathrm{E}-03$ & - & $<1.37 \mathrm{E}-04$ & NA & NA & - \\
\hline${ }^{241} \mathrm{Am} \quad(\mathrm{SG})$ & $6.99 \mathrm{E}-01$ & $1.01 \mathrm{E}+00$ & $7.10 \mathrm{E}-01$ & $8.06 \mathrm{E}-01$ & 22 & $5.05 \mathrm{E}-05$ & $\overline{\mathrm{NA}}$ & $\overline{\mathrm{NA}}$ & $\overline{U_{R}}$ \\
\hline${ }^{243} \mathrm{Am} \quad(\mathrm{SA})$ & $1.02 \mathrm{E}-03$ & $1.86 \mathrm{E}-03$ & $1.03 \mathrm{E}-03$ & $1.30 \mathrm{E}-03$ & 37 & $3.03 \mathrm{E}-06$ & NA & NA & $\mathrm{U}_{\mathrm{M}} \mathrm{U}_{\mathrm{R}}$ \\
\hline${ }^{244} \mathrm{Cm} \quad(\mathrm{SA})$ & $4.92 \mathrm{E}-02$ & $3.48 \mathrm{E}-02$ & $2.70 \mathrm{E}-02$ & $3.70 \mathrm{E}-02$ & 30 & $2.32 \mathrm{E}-04$ & $\overline{\mathrm{NA}}$ & $\overline{\mathrm{NA}}$ & $\mathrm{U}_{\mathrm{R}}$ \\
\hline${ }^{242} \mathrm{Cm} \quad$ (SA) & $2.63 \mathrm{E}-03$ & $3.37 \mathrm{E}-03$ & $2.95 \mathrm{E}-03$ & $2.98 \mathrm{E}-03$ & 12 & $5.00 \mathrm{E}-07$ & NA & NA & $\mathrm{U}_{\mathrm{M}}$ \\
\hline
\end{tabular}

* Average of two replicates

QC Flags: none - meets all QC

$\mathrm{U}_{\mathrm{R}}$ - fails \%RSD criteria

$\mathrm{U}_{\mathrm{M}}$ - fails minimum MRQ criteria

$\mathrm{U}_{\mathrm{B}}$ - blank exceeds $5 \%$ of sample concentration

$\mathrm{U}_{\mathrm{L}}$ - fails \% Recovery of LCS

$\mathrm{U}_{\mathrm{S}}$ - fails \% Recovery of MS

$\mathrm{U}_{\mathrm{E}}$ - value less than $10 \mathrm{x}$ the $\mathrm{DL}$

ND - not detected

N/A - not applicable

N/M- not measured 
WSRC-TR-2003-00210, REVISION 0 SRT-RPP-2003-00091, REVISION 0

Table 6-6. Composition of the Microwave Digested As-Received 241-AN-107 Centrifuged Solids

\begin{tabular}{|c|c|c|c|c|c|c|c|c|c|c|}
\hline Analyte & $\begin{array}{c}1^{\text {st }} \\
\text { Replicate } \\
\text { (mg/kg) }\end{array}$ & $\begin{array}{c}2^{\text {nd }} \\
\text { Replicate } \\
(\mathbf{m g} / \mathbf{k g})\end{array}$ & $\begin{array}{c}3^{\text {rd }} \\
\text { Replicate } \\
(\mathbf{m g} / \mathbf{k g})\end{array}$ & $\begin{array}{c}\text { Average } \\
\text { (mg/kg) }\end{array}$ & $\%$ RSD & $\begin{array}{c}\text { Blank } \\
(\mathrm{mg} / \mathbf{k g})\end{array}$ & $\begin{array}{c}\text { Glass Std. } \\
(\mathrm{mg} / \mathbf{k g})\end{array}$ & $\begin{array}{c}\text { LCS \% } \\
\text { Recovery }\end{array}$ & $\begin{array}{c}\text { MS \% } \\
\text { Recovery }\end{array}$ & $\begin{array}{c}\text { QC } \\
\text { Flag }\end{array}$ \\
\hline $\mathrm{Ag} \quad$ (IE) & $<10.6$ & $<13.7$ & $<10.6$ & $<11.63$ & - & $<11.5$ & $<32.9$ & 100 & NA & $\mathrm{U}_{\mathrm{M}}$ \\
\hline (IE) & 260 & 300 & 231 & 264 & 13 & 47.2 & 22100 & 104 & NA & $\mathrm{U}_{\mathrm{B}} \mathrm{U}_{\mathrm{M}} \mathrm{U}_{\mathrm{E}}$ \\
\hline $\mathrm{Ba} \quad$ (IE) & $<25.2$ & $<32.6$ & $<25.1$ & $<27.63$ & - & $<27.2$ & 867 & 99 & 104 & $\mathrm{U}_{\mathrm{M}}$ \\
\hline $\mathrm{Be} \quad$ (IE) & $<5.11$ & $<6.62$ & $<5.11$ & $<5.61$ & - & $<5.53$ & 19.8 & 99 & NA & - \\
\hline $\mathrm{Ca} \quad$ (IE) & 737 & 716 & 494 & 649 & 21 & $<33$ & 10100 & 94 & NA & $\mathrm{U}_{\mathrm{R}}$ \\
\hline $\mathrm{Cd}$ (IE) & 41.1 & 47 & 32 & 40 & 19 & $<6.02$ & $<17.3$ & 97 & 97 & $\mathrm{U}_{\mathrm{E}} \mathrm{U}_{\mathrm{R}}$ \\
\hline $\mathrm{Cr} \quad$ (IE) & 122 & 154 & 73.7 & 117 & 35 & $<8.6$ & 669 & 96 & 102 & $\mathrm{U}_{\mathrm{R}} \mathrm{U}_{\mathrm{M}}$ \\
\hline $\mathrm{Cu} \quad(\mathrm{IE})$ & 26.5 & 28.6 & 21.3 & 25 & 14.76 & 8.54 & 53.6 & 99 & NA & $\mathrm{U}_{\mathrm{B}}$ \\
\hline $\mathrm{Fe} \quad(\mathrm{IE})$ & 1350 & 1530 & 908 & 1263 & 25 & 49.5 & 101000 & 98 & 102 & $\mathrm{U}_{\mathrm{R}}$ \\
\hline $\mathrm{La} \quad$ (IE) & 30.3 & 42.8 & 28.1 & 34 & 23 & 10.8 & 66.5 & 100 & NA & $\mathrm{U}_{\mathrm{B}} \mathrm{U}_{\mathrm{R}} \mathrm{U}_{\mathrm{M}}$ \\
\hline $\mathrm{Li} \quad$ (IE) & $<57$ & $<73.8$ & $<56.9$ & $<62.57$ & - & $<61.6$ & 15300 & 95 & NA & - \\
\hline $\mathrm{Mg} \quad(\mathrm{IE})$ & $<7.02$ & $<9.09$ & $<7.01$ & $<7.71$ & - & $<7.59$ & 5320 & 98 & NA & $\mathrm{U}_{\mathrm{M}}$ \\
\hline $\mathrm{Mn}$ & 419 & 503 & 300 & 407 & 25 & $<1.15$ & 15100 & 98 & NA & $\mathrm{U}_{\mathrm{R}}$ \\
\hline (IE) & 159000 & 188000 & 118000 & 155000 & 23 & 96.6 & 65500 & 95 & 103 & $\mathrm{U}_{\mathrm{R}}$ \\
\hline $\mathrm{Ni} \quad$ (IE) & 383 & 489 & 284 & 385 & 27 & $<19.3$ & 8920 & 102 & 106 & $\mathrm{U}_{\mathrm{R}}$ \\
\hline (IE) & 182 & $<118$ & $<91.3$ & 182 & - & $<98.9$ & 509 & 99 & NA & $\mathrm{U}_{\mathrm{E}} \mathrm{U}_{\mathrm{M}}$ \\
\hline (IE) & 236 & 371 & 120 & 242 & 52 & $<45.7$ & $<131$ & 100 & NA & $\mathrm{U}_{\mathrm{R}} \mathrm{U}_{\mathrm{E}} \mathrm{U}_{\mathrm{M}}$ \\
\hline (IE) & 4120 & 4680 & 3190 & 3997 & 19 & 2060 & 7410 & 96 & NA & $\mathrm{U}_{\mathrm{B}} \mathrm{U}_{\mathrm{R}}$ \\
\hline (IE) & 552 & 434 & 340 & 442 & 24 & 326 & 206000 & 98 & NA & $\mathrm{U}_{\mathrm{B}} \mathrm{U}_{\mathrm{R}}$ \\
\hline (IE) & 164 & 158 & 101 & 141 & 25 & $<10.9$ & 2290 & 100 & NA & $\mathrm{U}_{\mathrm{R}}$ \\
\hline$(\mathrm{IE})$ & $<10.2$ & $<13.2$ & $<10.2$ & $<11$ & - & $<11$ & 7080 & 99 & NA & $\mathrm{U}_{\mathrm{M}}$ \\
\hline (IE) & $<301$ & $<389$ & $<300$ & $<330$ & - & $<325$ & 2800 & 100 & NA & - \\
\hline (IE) & 15.2 & 16.7 & 11.3 & 14 & 19 & 9.36 & 155 & 99 & NA & $\mathrm{U}_{\mathrm{B}} \mathrm{U}_{\mathrm{E}} \mathrm{U}_{\mathrm{R}}$ \\
\hline (IE) & $<4.24$ & $<5.49$ & $<4.23$ & $<5$ & - & $<4.58$ & 139 & 97 & NA & $\mathrm{U}_{\mathrm{M}}$ \\
\hline $\mathrm{Zr} \quad(\mathrm{IE})$ & 50.1 & 58.4 & 32.4 & 47 & 28 & $<32.7$ & 1020 & & NA & $\mathrm{U}_{\mathrm{R}} \mathrm{U}_{\mathrm{E}} \mathrm{U}_{\mathrm{M}}$ \\
\hline
\end{tabular}


WSRC-TR-2003-00210, REVISION 0 SRT-RPP-2003-00091, REVISION 0

Table 6-6. Composition of the Microwave Digested As-Received 241-AN-107 Centrifuged Solids (page 2 of 4 )

\begin{tabular}{|c|c|c|c|c|c|c|c|c|c|c|}
\hline Analyte & $\begin{array}{c}1^{\text {st }} \\
\text { Replicate } \\
\text { (mg/kg) }\end{array}$ & $\begin{array}{c}2^{\text {nd }} \\
\text { Replicate } \\
(\mathrm{mg} / \mathrm{kg})\end{array}$ & $\begin{array}{c}3^{\text {rd }} \\
\text { Replicate } \\
(\mathbf{m g} / \mathbf{k g})\end{array}$ & $\begin{array}{c}\text { Average } \\
\text { (mg/kg) }\end{array}$ & \%RSD & $\begin{array}{c}\text { Blank } \\
\text { (mg/kf) }\end{array}$ & $\begin{array}{c}\text { Glass Std. } \\
\text { (mg/kg) }\end{array}$ & $\begin{array}{c}\text { LCS \% } \\
\text { Recovery }\end{array}$ & $\begin{array}{c}\text { MS \% } \\
\text { Recovery }\end{array}$ & $\begin{array}{c}\text { QC } \\
\text { Flag }\end{array}$ \\
\hline As (AA) & $<18.3$ & $<18.5$ & $<22.1$ & $<19.6$ & - & $<18.27$ & $<21.5$ & 119.1 & 88.2 & - \\
\hline $\mathrm{K} \quad(\mathrm{AA})$ & 969 & 1060 & 955 & 995 & 6 & $<60.9$ & 22200 & 99.2 & 105 & - \\
\hline $\mathrm{Na} \quad(\mathrm{AA})$ & 151000 & 163000 & 150000 & 154667 & 5 & $<4153$ & 73800 & 95.4 & 102 & $\mathrm{U}_{\mathrm{R}}$ \\
\hline Se $\quad(A A)$ & $<18.3$ & $<18.5$ & $<22.1$ & $<19.6$ & - & $<18.27$ & $<21.5$ & 104.5 & 106 & $\mathrm{U}_{\mathrm{M}}$ \\
\hline $\mathrm{Hg} \quad$ (AA) & $<44.7$ & $<45.2$ & $<54.0$ & $<48.0$ & - & $<44.66$ & $<52.5$ & 95.6 & 98.3 & - \\
\hline Th $\quad$ (IM) & 37 & 27 & 24 & 29 & 24 & 12 & 9 & NA & 113 & $\mathrm{U}_{\mathrm{R}} \mathrm{U}_{\mathrm{M}}$ \\
\hline${ }^{233} \mathrm{U} \quad(\mathrm{IM})$ & $<1.39$ & $<1.39$ & $<1.39$ & $<1.39$ & - & $<1.39$ & $<1.39$ & NA & NA & - \\
\hline${ }^{234} \mathrm{U} \quad$ (IM) & $<1.39$ & $<1.39$ & $<1.39$ & $<1.39$ & - & $<1.39$ & $<1.39$ & NA & NA & - \\
\hline${ }^{235} \mathrm{U} \quad$ (IM) & $<1.39$ & $<1.39$ & $<1.39$ & $<1.39$ & - & $<1.39$ & $<1.39$ & 125 & NA & $\mathrm{U}_{\mathrm{L}}$ \\
\hline${ }^{236} \mathrm{U} \quad$ (IM) & $<1.39$ & $<1.39$ & $<1.39$ & $<1.39$ & - & $<1.39$ & $<1.39$ & NA & NA & - \\
\hline${ }^{237} \mathrm{~Np} \quad$ (IM) & $<1.39$ & $<1.39$ & $<1.39$ & $<1.39$ & - & $<1.39$ & $<1.39$ & NA & NA & - \\
\hline${ }^{238} \mathrm{U} \quad(\mathrm{IM})$ & 81 & 89 & 94 & 88 & 8 & $<1.39$ & 10 & 110 & 114 & - \\
\hline${ }^{239} \mathrm{Pu} \quad$ (IM) & $<1.39$ & $<1.39$ & $<1.39$ & $<1.39$ & - & $<1.39$ & $<1.39$ & NA & NA & - \\
\hline${ }^{240} \mathrm{Pu} \quad(\mathrm{IM})$ & $<1.39$ & $<1.39$ & $<1.39$ & $<1.39$ & - & $<1.39$ & $<1.39$ & NA & NA & - \\
\hline Total U (IM) & 81 & 89 & 94 & 88 & 8 & $<1.39$ & 10 & NA & NA & - \\
\hline $\mathrm{V} \quad(\mathrm{IM})$ & 166 & 159 & 184 & 170 & 8 & 191 & 330 & 124 & NA & $\mathrm{U}_{\mathrm{B}} \mathrm{U}_{\mathrm{L}}$ \\
\hline Co $\quad$ (IM) & 120 & 124 & 110 & 118 & 6 & $<113$ & 229 & 131 & NA & $\mathrm{U}_{\mathrm{L}}$ \\
\hline (IM) & $<20$ & $<20$ & $<20$ & $<20$ & - & $<20$ & $<20$ & 111 & NA & - \\
\hline $\mathrm{Se} \quad(\mathrm{IM})$ & $<300$ & $<300$ & $<300$ & $<300$ & - & $<300$ & $<300$ & NA & NA & $\mathrm{U}_{\mathrm{M}}$ \\
\hline (IM) & 39 & 52 & 53 & 48 & 16 & $<10$ & $<10$ & NA & 93 & $\mathrm{U}_{\mathrm{R}}$ \\
\hline $\mathrm{Ru} \quad(\mathrm{IM})$ & 48 & 59 & 35 & 48 & 25 & $<0.7$ & $<0.7$ & NA & NA & $\mathrm{U}_{\mathrm{R}} \mathrm{U}_{\mathrm{M}}$ \\
\hline Mo $\quad$ (IM) & 27 & 30 & 16 & 24 & 29 & $<30$ & 47 & 117 & NA & $\mathrm{U}_{\mathrm{R}} \mathrm{U}_{\mathrm{M}}$ \\
\hline $\mathrm{Pd} \quad$ (IM) & 12 & 15 & 11 & 13 & 15 & $<4.8$ & 12 & NA & NA & $\mathrm{U}_{\mathrm{M}}$ \\
\hline $\mathrm{Sb} \quad(\mathrm{IM})$ & $<12$ & $<12$ & $<12$ & $<12$ & - & $<12$ & $<12$ & 112 & NA & $\mathrm{U}_{\mathrm{M}}$ \\
\hline (IM) & $<6$ & $<6$ & $<6$ & $<6$ & - & $<6$ & $<6$ & NA & NA & $\mathrm{U}_{\mathrm{M}}$ \\
\hline
\end{tabular}


WSRC-TR-2003-00210, REVISION 0 SRT-RPP-2003-00091, REVISION 0

Table 6-6. Composition of the Microwave Digested As-Received 241-AN-107 Centrifuged Solids (page 3 of 4 )

\begin{tabular}{|c|c|c|c|c|c|c|c|c|c|c|}
\hline Analyte & $\begin{array}{c}1^{\text {st }} \\
\text { Replicate } \\
\text { (mg/kg) }\end{array}$ & $\begin{array}{c}2^{\text {nd }} \\
\text { Replicate } \\
(\mathrm{mg} / \mathrm{kg})\end{array}$ & $\begin{array}{c}3^{\text {rd }} \\
\text { Replicate } \\
(\mathrm{mg} / \mathrm{kg})\end{array}$ & $\begin{array}{c}\text { Average } \\
\text { (mg/kg) }\end{array}$ & $\%$ RSD & $\begin{array}{c}\text { Blank } \\
(\mathrm{mg} / \mathrm{kg})\end{array}$ & $\begin{array}{c}\text { Glass Std. } \\
(\mathrm{mg} / \mathrm{kg})\end{array}$ & $\begin{array}{c}\text { LCS \% } \\
\text { Recovery }\end{array}$ & $\begin{array}{c}\text { MS \% } \\
\text { Recovery }\end{array}$ & $\begin{array}{c}\text { QC } \\
\text { Flag }\end{array}$ \\
\hline${ }^{133} \mathrm{Cs} \quad$ (IM) & 90 & 96 & 176 & 121 & 40 & 116 & 106 & NA & 105 & $\mathrm{U}_{\mathrm{B}} \mathrm{U}_{\mathrm{R}}$ \\
\hline${ }^{135} \mathrm{Cs} \quad$ (IM) & 5 & 5 & 5 & 5 & 0 & $<1.5$ & $<1.5$ & NA & NA & - \\
\hline${ }^{137} \mathrm{Cs} \quad(\mathrm{IM})$ & 10 & 10 & 10 & 10 & 0 & $<10$ & $<10$ & NA & NA & - \\
\hline $\mathrm{Ba} \quad(\mathrm{IM})$ & 13 & 14 & 14 & 13 & 6 & $<1$ & 804 & 110 & NA & $\mathrm{U}_{\mathrm{M}}$ \\
\hline $\mathrm{Ce} \quad(\mathrm{IM})$ & 189 & 218 & 185 & 197 & 9 & 11 & 98 & NA & NA & $\mathrm{U}_{\mathrm{B}}$ \\
\hline $\operatorname{Pr} \quad(\mathrm{IM})$ & $<300$ & $<300$ & $<300$ & $<300$ & - & $<300$ & $<300$ & NA & NA & - \\
\hline (IM) & 20 & 8 & 8 & 12 & 56 & $<6$ & 21 & NA & NA & $\mathrm{U}_{\mathrm{R}}$ \\
\hline (IM) & 120 & 128 & 122 & 124 & 3 & $<6$ & 7 & NA & NA & - \\
\hline (IM) & $<3$ & $<3$ & $<3$ & $<3$ & - & $<3$ & $<3$ & NA & NA & $\mathrm{U}_{\mathrm{M}}$ \\
\hline (IM) & $<5$ & $<5$ & $<5$ & $<5$ & - & $<5$ & $<5$ & NA & 107 & $\mathrm{U}_{\mathrm{M}}$ \\
\hline (IM) & 35 & 44 & 29 & 36 & 21 & $<0.4$ & $<0.4$ & 39 & NA & $\mathrm{U}_{\mathrm{R}} \mathrm{U}_{\mathrm{M}}$ \\
\hline (IM) & $<0.14$ & $<0.14$ & $<0.14$ & $<0.14$ & - & $<0.14$ & $<0.14$ & NA & NA & $\mathrm{U}_{\mathrm{M}}$ \\
\hline (IM) & 35 & 62 & 69 & 55 & 33 & $<5$ & $<5$ & NA & NA & $\mathrm{U}_{\mathrm{R}}$ \\
\hline (IM) & $<0.89$ & $<0.89$ & $<0.89$ & $<0.89$ & - & $<0.89$ & $<0.89$ & NA & NA & $\mathrm{U}_{\mathrm{M}}$ \\
\hline (IM) & 392 & 443 & 380 & 405 & 8 & $<12$ & 27 & NA & NA & $\mathrm{U}_{\mathrm{M}}$ \\
\hline
\end{tabular}

$\sim$ One Value

QC Flags: none - meets all QC

$\mathrm{U}_{\mathrm{B}}$ - blank exceeds $5 \%$ of sample concentration

$\mathrm{U}_{\mathrm{R}}$ - fails $\%$ RSD criteria

$\mathrm{U}_{\mathrm{E}}$ - value less than $10 \mathrm{x}$ the $\mathrm{DL}$

$\mathrm{U}_{\mathrm{L}}$ - fails \% Recovery of LCS

$\mathrm{U}_{\mathrm{M}}$ - fails minimum MRQ criteria

N/M- not measured

ND - not detected

$U_{S}$ - fails \% Recovery of MS

NA - not applicable 
WSRC-TR-2003-00210, REVISION 0 SRT-RPP-2003-00091, REVISION 0

Table 6-6. Composition of the Microwave Digested As-Received 241-AN-107 Centrifuged Solids (page 4 of 4 )

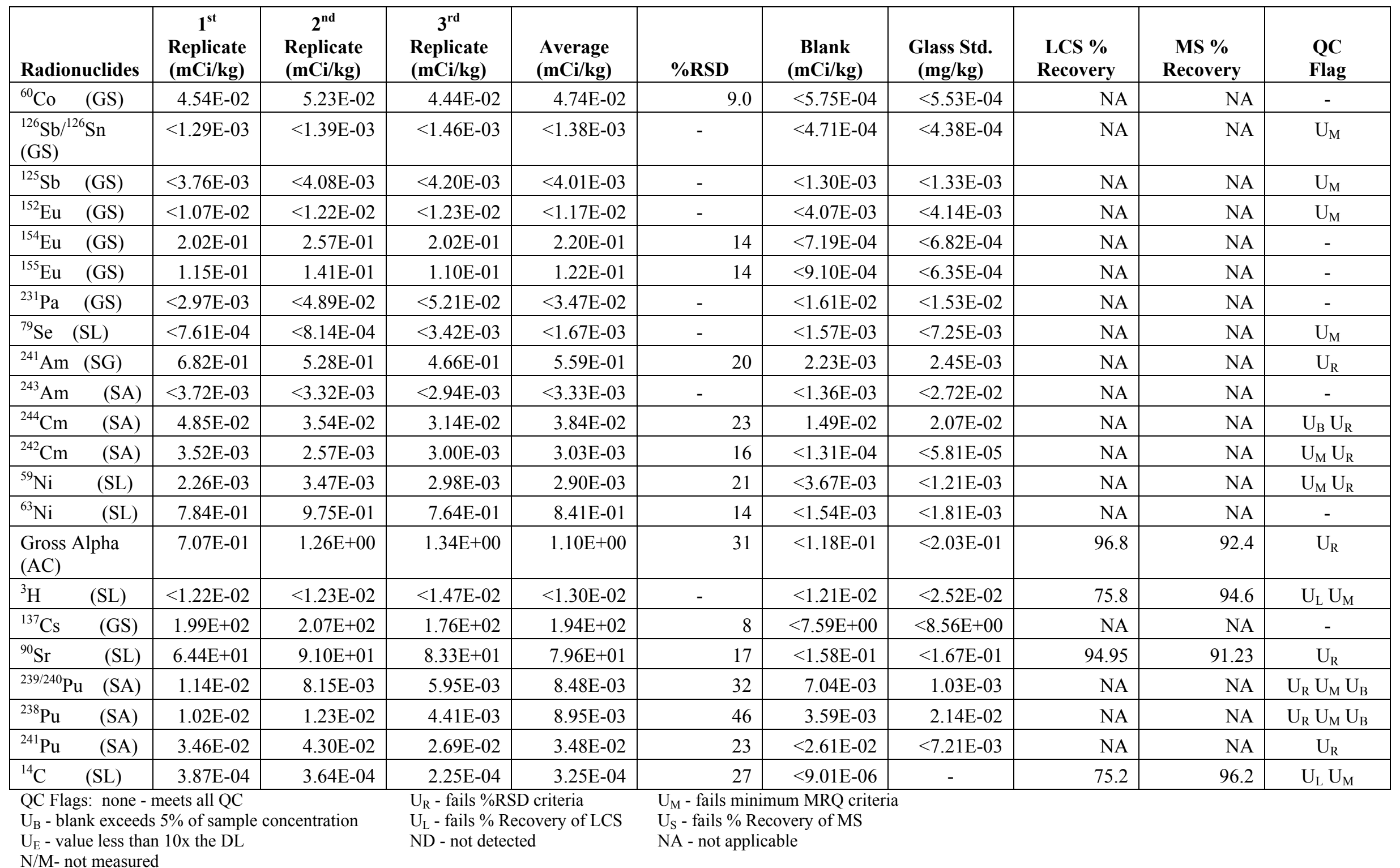


WSRC-TR-2003-00210, REVISION 0

SRT-RPP-2003-00091, REVISION 0

Table 6-7. Composition of the Aqua-Regia Digested As-Received 241-AN-107 Centrifuged Solids

\begin{tabular}{|c|c|c|c|c|c|c|c|c|c|c|}
\hline Analyte & $\begin{array}{c}1^{\text {st }} \\
\text { Replicate } \\
\text { (mg/kg) }\end{array}$ & $\begin{array}{c}2^{\text {nd }} \\
\text { Replicate } \\
(\mathbf{m g} / \mathbf{k g})\end{array}$ & $\begin{array}{c}3^{\text {rd }} \\
\text { Replicate } \\
(\mathrm{mg} / \mathrm{kg})\end{array}$ & $\begin{array}{c}\text { Average } \\
\text { (mg/kg) }\end{array}$ & $\%$ RSD & $\begin{array}{c}\text { Blank } \\
\text { (mg/kg) }\end{array}$ & $\begin{array}{c}\text { Glass Std. } \\
\text { (mg/kg) }\end{array}$ & $\begin{array}{c}\text { LCS \% } \\
\text { Recovery }\end{array}$ & $\begin{array}{c}\text { MS \% } \\
\text { Recovery }\end{array}$ & $\begin{array}{c}\text { QC } \\
\text { Flag }\end{array}$ \\
\hline $\mathrm{Ag} \quad$ (IE) & $<1.09$ & $<2.05$ & $<1.07$ & $<1.40$ & - & $<1.09$ & 6.13 & 102 & NA & $\mathrm{U}_{\mathrm{M}}$ \\
\hline $\mathrm{Al} \quad$ (IE) & 147 & 122 & 93 & 121 & 22 & 23 & 21300 & 100 & NA & $\mathrm{U}_{\mathrm{B}} \mathrm{U}_{\mathrm{M}} \mathrm{U}_{\mathrm{R}}$ \\
\hline B (IE) & $<3.8$ & $<7.16$ & $<3.73$ & $<4.90$ & - & $<3.8$ & 23700 & 91 & NA & - \\
\hline $\mathrm{Ba} \quad$ (IE) & $<2.58$ & $<4.86$ & $<2.53$ & $<3.32$ & - & $<2.58$ & 758 & 100 & 105 & $\mathrm{U}_{\mathrm{M}}$ \\
\hline $\mathrm{Be}^{*} \quad(\mathrm{IE})$ & 0.155 & $<0.256$ & 0.221 & 0.19 & 25 & 0.197 & 20.6 & 101 & NA & $\mathrm{U}_{\mathrm{E}} \mathrm{U}_{\mathrm{M}}$ \\
\hline $\mathrm{Ca}$ (IE) & 209 & 186 & 228 & 208 & 10 & 25 & 8940 & 100 & NA & $\mathrm{U}_{\mathrm{B}}$ \\
\hline $\mathrm{Cd}$ (IE) & 9 & 8 & 15 & 11 & 36 & $<0.57$ & 18.9 & 100 & 105 & $\mathrm{U}_{\mathrm{R}}$ \\
\hline $\mathrm{Cr} \quad$ (IE) & 26 & 28 & 45 & 33 & 32 & 3 & 573 & 99 & 101 & $\mathrm{U}_{\mathrm{B}} \mathrm{U}_{\mathrm{R}}$ \\
\hline $\mathrm{Cu}$ (IE) & 8 & 9 & 10 & 9 & 11 & 11 & 41.2 & 99 & NA & $\mathrm{U}_{\mathrm{E}} \mathrm{U}_{\mathrm{M}} \mathrm{U}_{\mathrm{B}}$ \\
\hline $\mathrm{Fe} \quad(\mathrm{IE})$ & 575 & 310 & 464 & 450 & 30 & 30 & 88200 & 100 & 100 & $\mathrm{U}_{\mathrm{B}} \mathrm{U}_{\mathrm{R}}$ \\
\hline $\mathrm{Li} \quad$ (IE) & $<5.83$ & $<11$ & $<5.73$ & $<7.52$ & - & $<5.83$ & 13500 & 95 & NA & $\mathrm{U}_{\mathrm{M}}$ \\
\hline $\mathrm{Mg} \sim(\mathrm{IE})$ & 14 & $<1.36$ & $<0.706$ & 14 & - & $<0.719$ & 4710 & 101 & NA & $\mathrm{U}_{\mathrm{M}}$ \\
\hline $\mathrm{Mn} \quad$ (IE) & 112 & 97 & 149 & 119 & 22 & 0.134 & 13400 & 100 & NA & $\mathrm{U}_{\mathrm{M}} \mathrm{U}_{\mathrm{R}}$ \\
\hline $\mathrm{Ni}$ (IE) & 75 & 97 & 136 & 102 & 30 & 3 & 7380 & 103 & 100 & $\mathrm{U}_{\mathrm{M}} \mathrm{U}_{\mathrm{R}}$ \\
\hline $\mathrm{P} \quad$ (IE) & 77 & 86 & 129 & 97 & 29 & 23 & 746 & 102 & NA & $\mathrm{U}_{\mathrm{B}} \mathrm{U}_{\mathrm{M}} \mathrm{U}_{\mathrm{R}}$ \\
\hline $\mathrm{Pb} \quad$ (IE) & 51 & 59 & 97 & 69 & 36 & $<4.33$ & 14.5 & 99 & NA & $\mathrm{U}_{\mathrm{M}} \mathrm{U}_{\mathrm{R}}$ \\
\hline $\mathrm{S} \quad$ (IE) & 393 & 458 & 756 & 536 & 36 & $<18.6$ & 943 & 99 & NA & $\mathrm{U}_{\mathrm{R}}$ \\
\hline $\mathrm{Si} \sim(\mathrm{IE})$ & 4 & $<4.27$ & $<2.22$ & 4 & - & 4 & 5920 & 100 & NA & $\mathrm{U}_{\mathrm{E}} \mathrm{U}_{\mathrm{M}}$ \\
\hline $\mathrm{Sr} \quad$ (IE) & 44 & 40 & 48 & 44 & 9 & 4 & 1900 & 101 & NA & $\mathrm{U}_{\mathrm{B}}$ \\
\hline $\mathrm{Ti} \quad$ (IE) & $<1.04$ & $<1.97$ & $<1.03$ & $<1.35$ & - & $<1.04$ & 5010 & N/A & NA & $\mathrm{U}_{\mathrm{M}}$ \\
\hline $\mathrm{U} \sim \quad$ (IE) & 80 & $<58.1$ & $<30.2$ & 80 & - & $<30.8$ & 2290 & 99 & NA & $\mathrm{U}_{\mathrm{E}} \mathrm{U}_{\mathrm{M}}$ \\
\hline $\mathrm{V} \quad(\mathrm{IE})$ & $<0.271$ & $<0.512$ & $<0.266$ & $<0.350$ & - & $<0.271$ & 102 & 100 & NA & $\mathrm{U}_{\mathrm{M}}$ \\
\hline $\mathrm{Zn} \quad$ (IE) & 3 & 6 & 8 & 6 & 44 & 5 & 184 & 99 & NA & $\mathrm{U}_{\mathrm{B}} \mathrm{U}_{\mathrm{R}}$ \\
\hline $\mathrm{Zr}^{*} \quad$ (IE) & 9 & $<5.83$ & 15 & 12 & 34 & $<3.09$ & $<9.99$ & 100 & NA & $\mathrm{U}_{\mathrm{E}} \mathrm{U}_{\mathrm{M}}$ \\
\hline
\end{tabular}


WSRC-TR-2003-00210, REVISION 0 SRT-RPP-2003-00091, REVISION 0

Table 6-7. Composition of the Aqua-Regia Digested As-Received 241-AN-107 Centrifuged Solids (page 2 of 4)

\begin{tabular}{|c|c|c|c|c|c|c|c|c|c|c|}
\hline Analyte & $\begin{array}{c}1^{\text {st }} \\
\text { Replicate } \\
(\mathrm{mg} / \mathrm{kg})\end{array}$ & $\begin{array}{c}2^{\text {nd }} \\
\text { Replicate } \\
\text { (mg/kg) }\end{array}$ & $\begin{array}{c}3^{\text {rd }} \\
\text { Replicate } \\
(\mathrm{mg} / \mathrm{kg})\end{array}$ & $\begin{array}{c}\text { Average } \\
\text { (mg/kg) }\end{array}$ & $\%$ RSD & $\begin{array}{c}\text { Blank } \\
(\mathrm{mg} / \mathrm{kg})\end{array}$ & $\begin{array}{c}\text { Glass Std. } \\
(\mathrm{mg} / \mathrm{kg})\end{array}$ & $\begin{array}{c}\text { LCS \% } \\
\text { Recovery }\end{array}$ & $\begin{array}{c}\text { MS \% } \\
\text { Recovery }\end{array}$ & $\begin{array}{c}\text { QC } \\
\text { Flag }\end{array}$ \\
\hline As (AA) & $<5.55$ & $<5.75$ & $<5.45$ & $<5.58$ & - & $<5.55$ & $<18$ & 90 & 119 & - \\
\hline $\mathrm{K} \quad(\mathrm{AA})$ & 244 & 322 & 445 & 337 & 30 & $<29.22$ & 20300 & 99 & 104 & $\mathrm{U}_{\mathrm{R}}$ \\
\hline $\mathrm{Na}$ (AA) & 105,000 & 116,000 & 165,000 & 128,667 & 25 & $<3481$ & 196000 & 96 & 106 & $\mathrm{U}_{\mathrm{R}}$ \\
\hline $\mathrm{Se} \quad(\mathrm{AA})$ & $<5.55$ & $<5.75$ & $<5.45$ & $<5.58$ & - & $<5.55$ & $<18$ & 119 & 115 & $\mathrm{U}_{\mathrm{M}}$ \\
\hline $\mathrm{Hg} \quad(\mathrm{AA})$ & $<13.6$ & $<14.1$ & $<13.3$ & $<13.67$ & - & $<13.56$ & $<43.8$ & 96 & 104 & - \\
\hline Th $\quad$ (IM) & 3.0 & 2.2 & 4.8 & 3.3 & 40 & 0.14 & 1.8 & 105 & 104 & $\mathrm{U}_{\mathrm{R}} \mathrm{U}_{\mathrm{M}}$ \\
\hline${ }^{233} \mathrm{U} \quad(\mathrm{IM})$ & 0.014 & $<0.013$ & $<0.013$ & 0.014 & - & $<0.013$ & $<0.013$ & NA & NA & $\mathrm{U}_{\mathrm{M}}$ \\
\hline${ }^{234} \mathrm{U} \quad$ (IM) & $<0.013$ & $<0.013$ & $<0.013$ & $<0.013$ & - & $<0.013$ & $<0.013$ & NA & NA & $\mathrm{U}_{\mathrm{M}}$ \\
\hline${ }^{235} \mathrm{U} \quad$ (IM) & 0.43 & 0.23 & 0.20 & 0.29 & 43 & 0.017 & 0.08 & 101 & NA & $\mathrm{U}_{\mathrm{R}} \mathrm{U}_{\mathrm{B}}$ \\
\hline${ }^{236} \mathrm{U}^{*} \quad(\mathrm{IM})$ & 0.05 & 0.02 & $<0.013$ & 0.03 & 59 & $<0.013$ & $<0.013$ & NA & NA & $\mathrm{U}_{\mathrm{E}} \mathrm{U}_{\mathrm{R}}$ \\
\hline${ }^{237} \mathrm{~Np} \quad(\mathrm{IM})$ & 0.07 & 0.03 & 0.04 & 0.04 & 49 & $<0.013$ & $<0.013$ & NA & NA & $\mathrm{U}_{\mathrm{E}} \mathrm{U}_{\mathrm{R}}$ \\
\hline${ }^{238} \mathrm{U} \quad(\mathrm{IM})$ & 82 & 26 & 32 & 46.7 & 66 & 1.80 & 10.7 & 100 & 115 & $\mathrm{U}_{\mathrm{R}}$ \\
\hline Total U (IM) & 82.80 & 26.26 & 32.07 & 47.0 & 66 & 1.82 & 10.82 & NA & NA & $\mathrm{U}_{\mathrm{R}}$ \\
\hline (IM) & 21 & 4 & 11 & 11.8 & 73 & 20 & 189 & 111 & NA & $\mathrm{U}_{\mathrm{R}} \mathrm{U}_{\mathrm{B}}$ \\
\hline $\mathrm{Co} \quad(\mathrm{IM})$ & 1 & 1 & 2 & 1.3 & 26 & $<0.25$ & 64 & 115 & NA & $\mathrm{U}_{\mathrm{R}} \mathrm{U}_{\mathrm{M}}$ \\
\hline (IM) & 1 & $<0.46$ & 1 & 0.9 & 40 & 1 & 8 & 112 & NA & $\mathrm{U}_{\mathrm{R}} \mathrm{U}_{\mathrm{M}} \mathrm{U}_{\mathrm{B}}$ \\
\hline $\mathrm{Se} \quad(\mathrm{IM})$ & $<0.12$ & $<0.12$ & $<0.12$ & $<0.12$ & - & $<0.12$ & $<0.12$ & 105 & NA & $\mathrm{U}_{\mathrm{M}}$ \\
\hline $\mathrm{Rb} \quad$ (IM) & 1.8 & 2.4 & 3.2 & 2.5 & 29 & 0.14 & 58.8 & NA & 105 & $\mathrm{U}_{\mathrm{R}} \mathrm{U}_{\mathrm{M}} \mathrm{U}_{\mathrm{B}}$ \\
\hline $\mathrm{Ru} \quad(\mathrm{IM})$ & 4.9 & 3.8 & 8.4 & 5.7 & 42 & $<0.03$ & $<0.03$ & NA & NA & $\mathrm{U}_{\mathrm{R}} \mathrm{U}_{\mathrm{M}}$ \\
\hline Mo $\quad(\mathrm{IM})$ & 4.1 & 3.2 & 7.4 & 4.9 & 46 & 0.1 & 2.2 & 105 & NA & $\mathrm{U}_{\mathrm{R}} \mathrm{U}_{\mathrm{M}}$ \\
\hline $\mathrm{Pd} \quad(\mathrm{IM})$ & 2.0 & 0.7 & 2.6 & 1.7 & 56 & $<0.03$ & 0.9 & NA & NA & $\mathrm{U}_{\mathrm{R}} \mathrm{U}_{\mathrm{M}}$ \\
\hline (IM) & 0.04 & 0.05 & 0.08 & 0.1 & 37 & 0.06 & 1.25 & 102 & NA & $\mathrm{U}_{\mathrm{R}} \mathrm{U}_{\mathrm{M}} \mathrm{U}_{\mathrm{B}}$ \\
\hline (IM) & $<0.08$ & $<0.08$ & $<0.08$ & $<0.08$ & - & $<0.08$ & $<0.08$ & NA & NA & $\mathrm{U}_{\mathrm{M}}$ \\
\hline${ }^{133} \mathrm{Cs} \quad$ (IM) & 1.44 & 1.92 & 2.64 & 2.0 & 30 & $<0.03$ & 6 & NA & 110 & $\mathrm{U}_{\mathrm{R}}$ \\
\hline${ }^{135} \mathrm{Cs} \quad(\mathrm{IM})$ & 0.41 & 0.3 & 0.5 & 0.4 & 16 & 0.06 & $<0.03$ & NA & NA & $\mathrm{U}_{\mathrm{R}} \mathrm{U}_{\mathrm{B}}$ \\
\hline${ }^{137} \mathrm{Cs} \quad$ (IM) & 0.91 & 1.16 & 1.60 & 1.2 & 28 & 0.11 & $<0.004$ & NA & NA & $\mathrm{U}_{\mathrm{R}} \mathrm{U}_{\mathrm{B}}$ \\
\hline
\end{tabular}


WSRC-TR-2003-00210, REVISION 0 SRT-RPP-2003-00091, REVISION 0

Table 6-7. Composition of the Aqua-Regia Digested As-Received 241-AN-107 Centrifuged Solids (page 3 of 4 )

\begin{tabular}{|c|c|c|c|c|c|c|c|c|c|c|c|}
\hline \multicolumn{2}{|c|}{ Analyte } & $\begin{array}{c}1^{\text {st }} \\
\text { Replicate } \\
(\mathrm{mg} / \mathrm{kg})\end{array}$ & $\begin{array}{c}2^{\text {nd }} \\
\text { Replicate } \\
(\mathrm{mg} / \mathrm{kg})\end{array}$ & $\begin{array}{c}3^{\text {rd }} \\
\text { Replicate } \\
(\mathrm{mg} / \mathrm{kg})\end{array}$ & $\begin{array}{c}\text { Average } \\
\text { (mg/kg) }\end{array}$ & \%RSD & $\begin{array}{c}\text { Blank } \\
\text { (mg/kg) }\end{array}$ & $\begin{array}{c}\text { Glass Std. } \\
\text { (mg/kg) }\end{array}$ & $\begin{array}{c}\text { LCS \% } \\
\text { Recovery }\end{array}$ & $\begin{array}{c}\text { MS \% } \\
\text { Recovery }\end{array}$ & $\begin{array}{c}\text { QC } \\
\text { Flag }\end{array}$ \\
\hline $\mathrm{Ba}$ & (IM) & 1 & 2 & 2 & 1.6 & 30 & 0.641 & 770 & 105 & NA & $\mathrm{U}_{\mathrm{R}} \mathrm{U}_{\mathrm{M}} \mathrm{U}_{\mathrm{B}}$ \\
\hline $\mathrm{Ce}$ & (IM) & 6.0 & 6.9 & 10.6 & 7.8 & 31 & 0.073 & 9.2 & NA & NA & $\mathrm{U}_{\mathrm{R}}$ \\
\hline $\operatorname{Pr}$ & (IM) & 3.3 & 4.1 & 6.2 & 4.5 & 33 & 0.037 & 0.9 & NA & NA & $\mathrm{U}_{\mathrm{M}}$ \\
\hline $\mathrm{Ta}$ & (IM) & $<0.03$ & $<0.03$ & $<0.03$ & $<0.03$ & - & $<0.03$ & $<0.03$ & NA & NA & $\mathrm{U}_{\mathrm{M}}$ \\
\hline W & (IM) & 25 & 7 & 45 & 25.6 & 76 & 0.399 & 2 & 136 & 136 & $\mathrm{U}_{\mathrm{S}} \mathrm{U}_{\mathrm{R}}$ \\
\hline $\mathrm{Pt}$ & (IM) & $<0.3$ & $<0.3$ & $<0.3$ & $<0.3$ & - & $<0.3$ & $<0.3$ & NA & NA & $\mathrm{U}_{\mathrm{M}}$ \\
\hline $\mathrm{Tl}$ & (IM) & $<0.2$ & $<0.2$ & $<0.2$ & $<0.2$ & - & $<0.2$ & $<0.2$ & NA & NA & $\mathrm{U}_{\mathrm{M}}$ \\
\hline $\mathrm{Rh}$ & (IM) & 1.4 & 1.0 & 2.6 & 1.7 & 49 & $<0.04$ & $<0.04$ & NA & NA & $\mathrm{U}_{\mathrm{R}} \mathrm{U}_{\mathrm{M}}$ \\
\hline $\mathrm{Pu}$ & (IM) & 0.24 & 0.09 & 0.23 & 0.2 & 44 & $<0.02$ & $<0.02$ & NA & NA & $\mathrm{U}_{\mathrm{R}} \mathrm{U}_{\mathrm{M}}$ \\
\hline $\mathrm{Y}$ & (IM) & 1.689 & 1.913 & 2.558 & 2.1 & 22 & 0.018 & 5.783 & NA & NA & $\mathrm{U}_{\mathrm{R}} \mathrm{U}_{\mathrm{M}}$ \\
\hline $\mathrm{Bi}$ & (IM) & $<0.3$ & $<0.3$ & $<0.3$ & $<0.3$ & - & 0.5 & 3.5 & NA & NA & $\mathrm{U}_{\mathrm{M}} \mathrm{U}_{\mathrm{B}}$ \\
\hline $\mathrm{Nd}$ & (IM) & 15.5 & 19.0 & 28.8 & 21.1 & 33 & 0.3 & 4.5 & NA & NA & $\mathrm{U}_{\mathrm{R}} \mathrm{U}_{\mathrm{M}}$ \\
\hline
\end{tabular}

$\sim$ One Value

* Average of two data points

QC Flags: none - meets all QC

$\mathrm{U}_{\mathrm{B}}$ - blank exceeds $5 \%$ of sample concentration

$\mathrm{U}_{\mathrm{E}}$ - value less than $10 \mathrm{x}$ the $\mathrm{DL}$

$\mathrm{U}_{\mathrm{R}}$ - fails \%RSD criteria

$\mathrm{U}_{\mathrm{L}}$ - fails \% Recovery of LCS

ND - not detected

$\mathrm{U}_{\mathrm{M}}$ - fails minimum MRQ criteria

$\mathrm{U}_{\mathrm{S}}$ - fails \% Recovery of MS

NA - not applicable

N/M- not measured 
WSRC-TR-2003-00210, REVISION 0 SRT-RPP-2003-00091, REVISION 0

Table 6-7. Composition of the Aqua-Regia Digested As-Received 241-AN-107 Centrifuged Solids (page 4 of 4 )

\begin{tabular}{|c|c|c|c|c|c|c|c|c|c|c|}
\hline Radionuclides & $\begin{array}{c}1^{\text {st }} \\
\text { Replicate } \\
\text { (mCi/kg) }\end{array}$ & $\begin{array}{c}2^{\text {nd }} \\
\text { Replicate } \\
\text { (mCi/kg) }\end{array}$ & $\begin{array}{c}3^{\text {rd }} \\
\text { Replicate } \\
\text { (mCi/kg) }\end{array}$ & $\begin{array}{c}\text { Average } \\
(\mathrm{mCi} / \mathbf{k g})\end{array}$ & \%RSD & $\begin{array}{c}\text { Blank } \\
(\mathrm{mCi} / \mathbf{k g})\end{array}$ & $\begin{array}{c}\text { Glass Std. } \\
(\mathrm{mg} / \mathrm{kg})\end{array}$ & $\begin{array}{c}\text { LCS \% } \\
\text { Recovery }\end{array}$ & $\begin{array}{c}\text { MS \% } \\
\text { Recovery }\end{array}$ & $\begin{array}{c}\text { QC } \\
\text { Flag }\end{array}$ \\
\hline${ }^{137} \mathrm{Cs} \quad$ (GS) & $4.49 \mathrm{E}+01$ & $4.96 \mathrm{E}+01$ & $7.34 \mathrm{E}+01$ & $5.60 \mathrm{E}+01$ & 27.4 & $<2.70 \mathrm{E}+00$ & $<8.74 \mathrm{E}+00$ & NA & NA & $\mathrm{U}_{\mathrm{R}}$ \\
\hline${ }^{3} \mathrm{H}^{*} \quad(\mathrm{SL})$ & $<6.04 \mathrm{E}-03$ & $<6.26 \mathrm{E}-03$ & - & $<6.15 \mathrm{E}-03$ & - & $<6.05 \mathrm{E}-03$ & $<1.15 \mathrm{E}-02$ & NA & NA & $\mathrm{U}_{\mathrm{M}}$ \\
\hline $\begin{array}{l}\text { Gross Alpha } \\
\text { (AC) }\end{array}$ & 4.19E-01 & $6.04 \mathrm{E}-01$ & $6.13 \mathrm{E}-01$ & $5.45 \mathrm{E}-01$ & 20.0 & 8.67E-02 & $<1.24 \mathrm{E}-01$ & NA & NA & $\mathrm{U}_{\mathrm{R}} \mathrm{U}_{\mathrm{B}}$ \\
\hline$(\mathrm{SL})$ & $1.97 \mathrm{E}+01$ & $1.95 \mathrm{E}+01$ & $3.04 \mathrm{E}+01$ & $2.32 \mathrm{E}+01$ & 26.8 & $1.68 \mathrm{E}-01$ & $2.90 \mathrm{E}-01$ & NA & NA & $\mathrm{U}_{\mathrm{M}} \mathrm{U}_{\mathrm{R}}$ \\
\hline${ }^{241} \mathrm{Am} \quad(\mathrm{SG})$ & $9.61 \mathrm{E}-02$ & $1.21 \mathrm{E}-01$ & $1.67 \mathrm{E}-01$ & $1.28 \mathrm{E}-01$ & 28.1 & 8.89E-03 & $5.15 \mathrm{E}-02$ & NA & NA & $\mathrm{U}_{\mathrm{R}} \mathrm{U}_{\mathrm{B}}$ \\
\hline${ }^{243} \mathrm{Am} \quad(\mathrm{SA})$ & $8.00 \mathrm{E}-04$ & $5.25 \mathrm{E}-04$ & $3.56 \mathrm{E}-04$ & $5.60 \mathrm{E}-04$ & 40.0 & $1.19 \mathrm{E}-04$ & $<9.94 \mathrm{E}-04$ & NA & NA & $\mathrm{U}_{\mathrm{R}} \mathrm{U}_{\mathrm{B}}$ \\
\hline${ }^{244} \mathrm{Cm} \quad(\mathrm{SA})$ & $1.89 \mathrm{E}-02$ & $2.20 \mathrm{E}-01$ & $5.33 \mathrm{E}-02$ & $9.74 \mathrm{E}-02$ & 110.4 & $1.57 \mathrm{E}-01$ & 4.13E-01 & NA & NA & $\mathrm{U}_{\mathrm{R}} \mathrm{U}_{\mathrm{B}}$ \\
\hline${ }^{242} \mathrm{Cm} \quad(\mathrm{SA})$ & 4.59E-04 & $6.80 \mathrm{E}-04$ & $6.60 \mathrm{E}-04$ & $6.00 \mathrm{E}-04$ & 20.3 & $1.24 \mathrm{E}-04$ & $1.37 \mathrm{E}-04$ & NA & NA & $\mathrm{U}_{\mathrm{M}} \mathrm{U}_{\mathrm{R}} \mathrm{U}_{\mathrm{B}}$ \\
\hline${ }^{238} \mathrm{Pu} \quad(\mathrm{SA})$ & $4.87 \mathrm{E}-02$ & $1.91 \mathrm{E}-02$ & $5.95 \mathrm{E}-03$ & $2.46 \mathrm{E}-02$ & 89.0 & $1.78 \mathrm{E}-02$ & $<3.39 \mathrm{E}-02$ & NA & NA & $\mathrm{U}_{\mathrm{R}} \mathrm{U}_{\mathrm{M}} \mathrm{U}_{\mathrm{B}}$ \\
\hline${ }^{239 / 240} \mathrm{Pu} \quad(\mathrm{SA})$ & $9.91 \mathrm{E}-03$ & $6.17 \mathrm{E}-03$ & $8.60 \mathrm{E}-03$ & $8.23 \mathrm{E}-03$ & 23.1 & $4.24 \mathrm{E}-03$ & $<4.55 \mathrm{E}-03$ & NA & NA & $\mathrm{U}_{\mathrm{R}} \mathrm{U}_{\mathrm{M}} \mathrm{U}_{\mathrm{B}}$ \\
\hline${ }^{241} \mathrm{Pu} \quad(\mathrm{SA})$ & $4.91 \mathrm{E}-02$ & $4.24 \mathrm{E}-02$ & $1.74 \mathrm{E}-02$ & $3.63 \mathrm{E}-02$ & 46.0 & $<8.22 \mathrm{E}-03$ & $<2.49 \mathrm{E}-02$ & NA & NA & $\mathrm{U}_{\mathrm{R}}$ \\
\hline$(\mathrm{SG})$ & $<6.98 \mathrm{E}-04$ & $<5.81 \mathrm{E}-04$ & $<7.21 \mathrm{E}-04$ & $<6.67 \mathrm{E}-04$ & - & $<4.32 \mathrm{E}-04$ & NA & NA & NA & $\mathrm{U}_{\mathrm{M}}$ \\
\hline
\end{tabular}

* Average of two data points

QC Flags: none - meets all QC

$\mathrm{U}_{\mathrm{B}}$ - blank exceeds $5 \%$ of sample concentration

$\mathrm{U}_{\mathrm{E}}$ - value less than $10 \mathrm{x}$ the $\mathrm{DL}$

$\mathrm{U}_{\mathrm{R}}$ - fails \%RSD criteria

$\mathrm{U}_{\mathrm{L}}$ - fails \% Recovery of LCS

$\mathrm{U}_{\mathrm{M}}$ - fails minimum MRQ criteria

ND - not detected

$\mathrm{U}_{\mathrm{S}}$ - fails \% Recovery of MS

NA - not applicable

$\mathrm{N} / \mathrm{M}$ - not measured 
WSRC-TR-2003-00210, REVISION 0

SRT-RPP-2003-00091, REVISION 0

Table 6-8. Composition of the Water Leach Digested As-Received 241-AN-107 Centrifuged Solids

\begin{tabular}{|c|c|c|c|c|c|c|c|c|c|}
\hline Analyte & $\begin{array}{c}1^{\text {st }} \\
\text { Replicate } \\
(\mathrm{mg} / \mathrm{kg})\end{array}$ & $\begin{array}{c}2^{\text {nd }} \\
\text { Replicate } \\
(\mathbf{m g} / \mathrm{kg})\end{array}$ & $\begin{array}{c}3^{\text {rd }} \\
\text { Replicate } \\
(\mathrm{mg} / \mathrm{kg})\end{array}$ & $\begin{array}{c}\text { Average } \\
\text { (mg/kg) }\end{array}$ & $\%$ RSD & $\begin{array}{c}\text { Blank } \\
\text { (mg/kg) }\end{array}$ & $\begin{array}{c}\text { LCS \% } \\
\text { Recovery }\end{array}$ & $\begin{array}{c}\text { MS \% } \\
\text { Recovery }\end{array}$ & $\begin{array}{c}\text { QC } \\
\text { Flag }\end{array}$ \\
\hline TIC (A) & 18600 & 18500 & 19700 & 18933 & 4 & 0 & 101 & 102 & - \\
\hline TOC (Diff) & 29500 & 30600 & 28700 & 29600 & 3 & 495 & 101 & 99.3 & - \\
\hline $\mathrm{F} \quad(\mathrm{IC})$ & 2000 & 1580 & 1828 & 1803 & 12 & $<2500$ & 95 & 112 & $\mathrm{U}_{\mathrm{M}}$ \\
\hline $\mathrm{CHO}_{2} \quad(\mathrm{IC})$ & 5000 & 4310 & 5091 & 4801 & 9 & $<12500$ & 90 & 109 & - \\
\hline $\mathrm{Cl} \quad(\mathrm{IC})$ & $<2500$ & $<2873$ & $<2611$ & $<2662$ & - & $<2500$ & 99 & 105 & - \\
\hline $\mathrm{NO}_{2} \quad(\mathrm{IC})$ & 32875 & 26868 & 31854 & 30532 & 11 & $<12500$ & 98 & 116 & - \\
\hline $\mathrm{NO}_{3} \quad(\mathrm{IC})$ & 122750 & 98994 & 119582 & 113775 & 11 & $<12500$ & 104 & 118 & - \\
\hline $\mathrm{PO}_{4} \quad(\mathrm{IC})$ & $<12500$ & $<14368$ & $<13055$ & $<13308$ & - & $<12500$ & 104 & 106 & - \\
\hline $\mathrm{SO}_{4} \quad(\mathrm{IC})$ & 4250 & 3592 & 4178 & 4006 & 9 & $<6250$ & 102 & 106 & - \\
\hline $\mathrm{C}_{2} \mathrm{O}_{4} \quad(\mathrm{IC})$ & 3625 & 3736 & 4178 & 3846 & 8 & $<12500$ & 99 & 108 & - \\
\hline $\mathrm{Br} \quad(\mathrm{IC})$ & $<12500$ & $<14368$ & $<13055$ & $<13308$ & - & $<12500$ & 103 & 107 & - \\
\hline $\begin{array}{l}\text { QC Flags: none } \\
\mathrm{U}_{\mathrm{B}} \text { - blank excee } \\
\mathrm{U}_{\mathrm{E}} \text { - value less th } \\
\mathrm{N} / \mathrm{M} \text { - not measur }\end{array}$ & $\begin{array}{l}\text { neets all QC } \\
5 \% \text { of sample } \\
10 x \text { the DL }\end{array}$ & ncentration & $\begin{array}{l}U_{R} \text { - fails } \% R \\
U_{L} \text { - fails } \% R \\
N D \text { - not dete }\end{array}$ & $\begin{array}{l}\text { criteria } \\
\text { overy of LCS } \\
\text { a }\end{array}$ & $\begin{array}{l}U_{M} \text { - fails min } \\
U_{S} \text { - fails \% R } \\
N A \text { - not appli }\end{array}$ & $\begin{array}{l}\text { Im MRQ crite } \\
\text { very of MS } \\
\text { le }\end{array}$ & & & \\
\hline
\end{tabular}


WSRC-TR-2003-00210, REVISION 0

SRT-RPP-2003-00091, REVISION 0

\subsection{COMPARISON OF THE AS-RECEIVED SUPERNATE 241-AN-107 SAMPLE TO SPECIFICATION 7}

Specification 7 defines the Low Activity Waste Envelopes A, B, and C and the compositional and radionuclide limits for each of those envelopes. The As-Received 241-AN-107 Envelope $\mathrm{C}$ sample meets all of the specification limits except for the TRU limit. The TRU concentration is slightly above the specification limit. The \%RSDs were high on these measurements and the overall uncertainty indicates that it is somewhere close to the limit, i.e., $+/-25-50 \%$. The sodium concentration is averaged between the values measured by ICP-ES and AA in Table 6-5.

Table 7-1. Comparison of As-Received 241-AN-107 Envelope C Filtered Supernate to Specification 7 Chemical Composition Limits

\begin{tabular}{|c|c|c|c|c|c|c|}
\hline Analyte & $\begin{array}{l}\text { Average } \\
\text { Value from } \\
\text { Table 6-5 } \\
\text { (M) }\end{array}$ & QC Flag & $\begin{array}{c}\text { Average } \\
\text { Analyte to } \\
\text { Na Molar } \\
\text { Ratio }\end{array}$ & $\begin{array}{c}\text { Specification 7, } \\
\text { Envelope C } \\
\text { Maximum } \\
\text { Ratio }\end{array}$ & $\begin{array}{c}\% \text { of } \\
\text { Maximum }\end{array}$ & $\begin{array}{c}\text { Meets } \\
\text { Specification } \\
7 \\
\end{array}$ \\
\hline $\mathrm{Al}$ & $1.13 \mathrm{E}-02$ & - & $1.32 \mathrm{E}-03$ & $2.50 \mathrm{E}-01$ & 1 & YES \\
\hline $\mathrm{Ba}$ & $6.55 \mathrm{E}-05$ & $\mathrm{U}_{\mathrm{E}}$ & 7.62E-06 & $1.00 \mathrm{E}-04$ & 8 & YES \\
\hline $\mathrm{Ca}$ & $1.41 \mathrm{E}-02$ & - & $1.64 \mathrm{E}-03$ & $4.00 \mathrm{E}-02$ & 4 & YES \\
\hline $\mathrm{Cd}$ & $6.41 \mathrm{E}-04$ & $\mathrm{U}_{\mathrm{M}}$ & $7.45 \mathrm{E}-05$ & 4.00E-03 & 2 & YES \\
\hline $\mathrm{Cl}$ & $3.93 \mathrm{E}-02$ & - & 4.57E-03 & $3.70 \mathrm{E}-02$ & 12 & YES \\
\hline $\mathrm{Cr}$ & $3.67 \mathrm{E}-03$ & - & $4.27 \mathrm{E}-04$ & $6.90 \mathrm{E}-03$ & 6 & YES \\
\hline $\mathrm{F}$ & $1.75 \mathrm{E}-01$ & - & $2.03 \mathrm{E}-02$ & $9.10 \mathrm{E}-02$ & 22 & YES \\
\hline $\mathrm{Fe}$ & $3.34 \mathrm{E}-02$ & - & $3.88 \mathrm{E}-03$ & $1.00 \mathrm{E}-02$ & 39 & YES \\
\hline $\mathrm{Hg}$ & $<1.14 \mathrm{E}-05$ & - & $<1.33 \mathrm{E}-06$ & $1.40 \mathrm{E}-05$ & 9 & YES \\
\hline K & $3.98 \mathrm{E}-02$ & - & 4.63E-03 & $1.80 \mathrm{E}-01$ & 3 & YES \\
\hline $\mathrm{La}$ & $2.55 \mathrm{E}-04$ & - & $2.97 \mathrm{E}-05$ & 8.30E-05 & 36 & YES \\
\hline $\mathrm{Ni}$ & $9.90 \mathrm{E}-03$ & - & $1.15 \mathrm{E}-03$ & $3.00 \mathrm{E}-03$ & 38 & YES \\
\hline $\mathrm{NO}_{2}$ & $1.32 \mathrm{E}+00$ & - & $1.54 \mathrm{E}-01$ & $3.80 \mathrm{E}-01$ & 40 & YES \\
\hline $\mathrm{NO}_{3}$ & $3.63 \mathrm{E}+00$ & - & 4.22E-01 & $8.00 \mathrm{E}-01$ & 53 & YES \\
\hline $\mathrm{Pb}$ & $2.22 \mathrm{E}-03$ & $\mathrm{U}_{\mathrm{M}}$ & $2.58 \mathrm{E}-04$ & $6.80 \mathrm{E}-04$ & 38 & YES \\
\hline $\mathrm{PO}_{4}$ & $9.96 \mathrm{E}-03$ & - & $1.16 \mathrm{E}-03$ & $3.80 \mathrm{E}-02$ & 3 & YES \\
\hline $\mathrm{SO}_{4}$ & $8.83 \mathrm{E}-02$ & - & $1.03 \mathrm{E}-02$ & $2.00 \mathrm{E}-02$ & 51 & YES \\
\hline TIC & $2.21 \mathrm{E}+00$ & $\mathrm{U}_{\mathrm{R}}$ & $2.58 \mathrm{E}-01$ & $3.00 \mathrm{E}-01$ & 86 & YES \\
\hline TOC & $2.77 \mathrm{E}+00$ & $\mathrm{U}_{\mathrm{R}}$ & $3.22 \mathrm{E}-01$ & $5.00 \mathrm{E}-01$ & 64 & YES \\
\hline $\mathrm{U}$ & $5.29 \mathrm{E}-04$ & - & $6.16 \mathrm{E}-05$ & $1.20 \mathrm{E}-03$ & 5 & YES \\
\hline
\end{tabular}

1) The total uranium was calculated from the ICP-MS values for mass 235 and 238 . 
WSRC-TR-2003-00210, REVISION 0

SRT-RPP-2003-00091, REVISION 0

Table 7-2. Comparison of As-Received 241-AN-107 Filtered Supernate to Specification 7 Radionuclide Limits

\begin{tabular}{|l|c|l|c|r|r|c|}
\hline $\begin{array}{c}\text { Radio- } \\
\text { nuclides }\end{array}$ & $\begin{array}{c}\text { Average } \\
\text { Value from } \\
\text { Table 6-5 } \\
\text { (M) }\end{array}$ & QC Flag & $\begin{array}{c}\text { Average } \\
\text { Analyte to } \\
\text { Natio }\end{array}$ & $\begin{array}{c}\text { Mpecification 7, } \\
\text { Ration } \\
\text { Envelope C } \\
\text { Maximum } \\
\text { Ratio }\end{array}$ & $\begin{array}{c}\text { \% of } \\
\text { Maximum }\end{array}$ & $\begin{array}{c}\text { Meets } \\
\text { Specification } \\
7\end{array}$ \\
\hline $\mathrm{TRU}^{1}$ & $3.35 \mathrm{E}+07$ & $\mathrm{U}_{\mathrm{R}}$ & $3.90 \mathrm{E}+06$ & $3.00 \mathrm{E}+06$ & 130 & NO \\
\hline${ }^{137} \mathrm{Cs}$ & $1.24 \mathrm{E}+10$ & - & $1.44 \mathrm{E}+09$ & $4.30 \mathrm{E}+09$ & 34 & YES \\
\hline${ }^{90} \mathrm{Sr}$ & $3.12 \mathrm{E}+09$ & $\mathrm{U}_{\mathrm{S}}$ & $3.62 \mathrm{E}+08$ & $8.00 \mathrm{E}+08$ & 45 & YES \\
\hline${ }^{99} \mathrm{Tc}$ & $3.85 \mathrm{E}+06$ & - & $4.47 \mathrm{E}+05$ & $7.10 \mathrm{E}+06$ & 6 & YES \\
\hline${ }^{60} \mathrm{Co}$ & $3.02 \mathrm{E}+06$ & $\mathrm{U}_{\mathrm{R}}$ & $3.51 \mathrm{E}+05$ & $3.70 \mathrm{E}+05$ & 95 & YES \\
\hline${ }^{154} \mathrm{Eu}$ & $1.60 \mathrm{E}+07$ & $\mathrm{U}_{\mathrm{R}}$ & $1.86 \mathrm{E}+06$ & $4.30 \mathrm{E}+06$ & 43 & YES \\
\hline
\end{tabular}

1) The TRU was calculated by summing the ${ }^{238} \mathrm{Pu},{ }^{239 / 240} \mathrm{Pu},{ }^{241} \mathrm{Am}$, and ${ }^{244} \mathrm{Cm}$ alpha spectroscopy results.

2) The ${ }^{99} \mathrm{Tc}$ result is from ${ }^{99} \mathrm{Tc}$ total.

$\mathrm{U}_{\mathrm{R}} \quad$ Fails \% RSD criteria

$\mathrm{U}_{\mathrm{S}} \quad$ Fails \% recovery of Matrix Spike 
WSRC-TR-2003-00210, REVISION 0

SRT-RPP-2003-00091, REVISION 0

\subsection{GENERAL DESCRIPTION OF ANALYTICAL PROCEDURES}

\subsection{INDUCTIVELY COUPLED PLASMA-ATOMIC EMISSION SPECTROSCOPY}

Samples were diluted as necessary to bring analytes within the instrument range. A scandium internal standard was added to all samples after dilution at a concentration of $2 \mathrm{mg} / \mathrm{L}$. Background and internal standard correction were applied to the results. An LCS containing the analytes of interest was run with the samples. A matrix spike containing $\mathrm{Ba}, \mathrm{Cd}, \mathrm{Cr}, \mathrm{Fe}$, $\mathrm{Na}$, and Ni was run with each set of samples. The subset of elements used for the matrix spike was specified in the task plan.

\subsection{ION CHROMATOGRAPHY FOR ANIONS AND ORGANICS ACIDS}

For IC Anions, samples were diluted with a carbonate/bicarbonate diluent as necessary to bring analytes to within instrument calibration. An LCS containing the analytes of interest was analyzed concurrently with samples. One sample replicate was spiked with known concentrations of the analytes of interest for each set of samples.

Organic acids were determined by ion exclusion chromatography (IEC). Samples were diluted in a high salt solution as necessary to bring analytes to within instrument calibration. A LCS containing the analytes of interest was analyzed concurrently with samples. One sample replicate was spiked with known concentrations of the analytes of interest for each set of samples.

\subsection{FREE HYDROXIDE AND TOTAL BASE TITRATIONS}

Total hydroxide (total base) was determined by titration to an inflection end point closest to $\mathrm{pH}$ 7.00. An LCS containing $1.00 \mathrm{~N} \mathrm{NaOH}$ was run in triplicate before and after each set of samples.

Free hydroxide was determined by incremental inflection point titration. The titration curves were examined to determine the free hydroxide concentration. A lab control standard containing hydroxide, aluminate, and carbonate was run in triplicate before and after each set of samples.

Carbonate was determined by precipitation using saturated barium chloride. The precipitate was dissolved in acid and the carbonate concentration determined via back titration. An LCS containing hydroxide, aluminate, and carbonate was run in triplicate before and after each set of samples.

No matrix spikes were performed on any of the base titrations. 


\section{WSRC-TR-2003-00210, REVISION 0 \\ SRT-RPP-2003-00091, REVISION 0}

\subsection{ATOMIC ABSORPTION SPECTROSCOPY}

Sodium, potassium, and mercury were analyzed by AA. The mercury was determined using the cold vapor technique. Samples were diluted as necessary to bring analytes within the instrument calibration range. An LCS containing the analyte of interest was run with the samples. A matrix spike containing the analyte of interest was made on one of the sample replicates for each set of samples.

\subsection{AMMONIA}

Ammonia was analyzed by ion (cation) chromatography after a purge and trap procedure to isolate the ammonia from the sample.

Due to high concentrations of sodium ions which interfere with the analysis of ammonium ions (NH4+), dissolved ammonia in the sample was purged using helium gas and trapped in an acidic solution for cation analysis. A 1-mL sample aliquot was added to a 2-molar hydroxide solution and purged for 15 minutes. An LCS containing the sample analyte was analyzed concurrently with samples. A sample replicate was spiked with the analyte at a known concentration, purged for 15 minutes, and trapped in an acidic solution for cations analysis. Measured values were adjusted to account for purge efficiency losses.

\subsection{ORGANICS}

EDTA and HEDTA were analyzed by Ion Pair Chromatography (IPC). The copper complex of EDTA and HEDTA were used as the LCS. For the matrix spike, EDTA and HEDTA were spiked into the sample followed by preparation and analysis.

IDA was analyzed by GC-MS. These compounds were converted from carboxylic acids to methyl esters by $\mathrm{BF}_{3} /$ methanol reagent for GC-MS analysis. The GC-MS instrument was calibrated using naphthalene-d8 as the LCS. The matrix spike was deuterated stearic- $\mathrm{d}_{35}$ acid which was compared to acid methyl ester. The IDA spike served as an internal standard.

\subsection{TOTAL INORGANIC CARBON/TOTAL ORGANIC CARBON}

Total carbon was determined by combustion at $780{ }^{\circ} \mathrm{C}$ in a stream of pure oxygen. The $\mathrm{CO}_{2}$ produced was then measured. The inorganic carbon was determined by injecting an aliquot into an acid medium purged by an oxygen stream. Again, the $\mathrm{CO}_{2}$ produced was then measured. By subtracting the inorganic carbon from the total carbon, the organic carbon was calculated. Instrument calibration used NIST traceable organic and inorganic standards before and after each set of samples. These standards also served as the LCS and were used for the matrix spike for the method. The matrix spike was made on one of the sample replicates. 


\subsection{INDUCTIVELY COUPLED PLASMA-MASS SPECTROMETRY}

Samples were run concurrently with an LCS containing V, Co, As, Sr, Mo, Ru, Ag, Cd, Sb, $\mathrm{Cs}, \mathrm{Ba}, \mathrm{La}, \mathrm{Eu}, \mathrm{Ho}, \mathrm{Yb}, \mathrm{Tl}, \mathrm{Pb}, \mathrm{Th}$, and $\mathrm{U}$. This LCS provided a mass response covering most of the mass range of interest. However, the LCS did not cover every mass of species of interest such as ${ }^{127} \mathrm{I}$, and $\mathrm{W}$ isotopes, so no LCS recovery was provided for these analytes. In general a matrix spike using the LCS was made on one of the sample replicates. For some of the sample results without matrix spike recoveries in the data tables, a matrix spike containing only $U$ was used. The following describes the calculation of the analytes of interest from the mass values:

$\begin{array}{ll}{ }^{\mathrm{Rb}} & \text { sum of mas } \\ { }^{99} \mathrm{Tc} & \text { mass } 99 . \mathrm{S} \\ { }^{127} \mathrm{I} & \text { mass } 127 . \\ { }^{133} \mathrm{Cs} & \text { mass } 133 \\ { }^{135} \mathrm{Cs} & \text { mass } 135 . \\ { }^{137} \mathrm{Cs} & \text { mass } 137 . \\ { }^{\mathrm{W}} & \text { Sum of mas } \\ & \text { summation. } \\ { }^{\mathrm{Th}} & \text { The isobar } \\ { }^{233} \mathrm{U} & \text { mass } 232 \\ { }^{234} \mathrm{U} & \text { mass } 234 \\ { }^{235} \mathrm{U} & \text { mass } 235 \\ { }^{236} \mathrm{U} & \text { mass } 236 \\ { }^{238} \mathrm{U} & \text { mass } 238 \\ { }^{237} \mathrm{~Np} & \text { mass } 237 \\ { }^{239} \mathrm{Pu} & \text { mass } 239 \\ { }^{240} \mathrm{Pu} & \text { mass } 240\end{array}$

ICP-MS determinations of radionuclides were reported in $\mu \mathrm{g} / \mathrm{g}$ of the supernatant. To convert these values to $\mathrm{mCi} / \mathrm{L}$ as required by the Test Specification, the density of the supernate and the specific activity of each radionuclide were used. The specific activity for each radionuclide was obtained from "Integrated Data Base Report-1994: U.S. Spent Nuclear Fuel and Radioactive Waste Inventories, Projections, and Characteristics," Appendix B, pages 277 and 280, DOE/RW-0006, September, 1995, prepared by the Oak Ridge National Laboratory. 


\subsection{ALPHA COUNTING}

Prior to the analysis, ${ }^{137} \mathrm{Cs}$ was removed from aliquots of the samples in order to reduce bias effects caused by large beta/alpha ratios. The ${ }^{137} \mathrm{Cs}$ removal was accomplished using Bio-Rad AMP1 resin. Following the Cs removal process, an aliquot of each stripped solution was added to a stainless steel planchet and analyzed for alpha activity.

\subsection{GAMMA SPECTROMETRY}

An aliquot of each sample was analyzed by gamma spectroscopy analysis using a high purity germanium detector. Results are background subtracted.

\section{$8.11{ }^{3}$ H ANALYSIS}

For the tritium analysis, an aliquot of each sample was subjected to a steam distillation to separate the tritium containing fraction from the remainder of the sample. An aliquot of each distillate was added to liquid scintillation cocktail to be analyzed for tritium. The samples were counted on a Packard Instruments liquid scintillation counter along with an instrument blank. The instrument blank was counted first and was used to establish an instrument background that was subtracted from the count results for the samples.

\subsection{2 ${ }^{99}$ Te ANALYSIS (FOR PERTECHNETATE FORM)}

${ }^{99 \mathrm{~m}}$ Tc tracers were generated initially by neutron irradiation of natural molybdenum using the SRTC Cf $\mathrm{C}^{252}$ Neutron Activation Analysis facility. ${ }^{98} \mathrm{Mo}$ was activated to ${ }^{99} \mathrm{Mo}$, which subsequently beta decays to ${ }^{99 \mathrm{~m}} \mathrm{Tc}$. The ${ }^{99 \mathrm{~m}} \mathrm{Tc}$ was then extracted from the ${ }^{99} \mathrm{Mo}$ to form a ${ }^{99 \mathrm{~m}}$ Tc tracer.

Aliquots of the sample were diluted with water, ${ }^{99 \mathrm{~m}} \mathrm{Tc}$ tracer was added, and the ${ }^{99} \mathrm{Tc}$ was subsequently extracted using an Aliquat 336 based extraction. Aliquat 336 extracts ${ }^{99} \mathrm{Tc}$ in the pertechnetate form. The extractant was then analyzed first by gamma spectroscopy to determine ${ }^{99 \mathrm{~m}} \mathrm{Tc}$ tracer recoveries, and then analyzed by liquid scintillation analysis to determine ${ }^{99} \mathrm{Tc}$. ${ }^{99 \mathrm{~m}} \mathrm{Tc}$ tracer recoveries were applied to the liquid scintillation results to quantify the ${ }^{99} \mathrm{Tc}$. A blank solution was also run through the extraction process to ensure no cross contamination existed at the laboratory level.

Pertechnetate is the thermodynamically stable form of technetium in oxidizing environments. It is presumed to be the predominant chemical form of technetium in the aqueous phase of nuclear waste tanks, however significant amounts of technetium appear in a different chemical form. Total technetium accounts for pertechnetate and non-pertenetate forms present. 


\section{WSRC-TR-2003-00210, REVISION 0 SRT-RPP-2003-00091, REVISION 0}

\section{$8.13{ }^{90} \mathrm{Sr}$ ANALYSIS}

An aliquot of each sample was analyzed for ${ }^{90} \mathrm{Sr}$ using an Eichrom Sr-Spec based extraction procedure. A ${ }^{90} \mathrm{Sr}$ spiked blank was analyzed with the sample batch to establish ${ }^{90} \mathrm{Sr} /{ }^{90} \mathrm{Y}$ counting efficiencies and $\mathrm{Sr}$ chemical recoveries. Aliquots of each sample's Sr extract were analyzed by neutron activation analysis to determine $\mathrm{Sr}$ carrier recoveries, the results of which were normalized to the results of the ${ }^{90} \mathrm{Sr}$ spiked blank sample so each sample could be yielded by the recovery of its stable Sr carrier recovery. The LCS and matrix spike samples were treated exactly like the samples. Once the extractions were complete, aliquots of the resultant ${ }^{90} \mathrm{Sr} /{ }^{90} \mathrm{Y}$ containing extracts mixed with liquid scintillation cocktail were counted in the ADS Radiochemistry Counting Facility. The samples were counted on a Packard Instruments liquid scintillation counter along with an instrument blank. The instrument blank was counted first and was used to establish an instrument background that was subtracted from the count results for the samples.

\subsection{4 ${ }^{79}$ Se ANALYSIS}

Aliquots of the sample were spiked initially with stable Se which acted as both a chemical carrier and a Se yield tracer for the ${ }^{79}$ Se measurements. The samples were then oxidized. Next the solutions were reduced to precipitate out Se metal. The Se metal was washed repeatedly, redissolved, and the dissolution was then subjected to a series of decontamination steps with several types of analytical resins added in batch mode, which were subsequently filtered off. The decontaminated solutions were then concentrated. Aliquots of the concentrate were analyzed by neutron activation analysis to determine Se carrier yields, and by liquid scintillation to measure ${ }^{79}$ Se activities.

\subsection{ALPHA SPECTROSCOPY FOR PLUTONIUM ISOTOPICS}

An aliquot of each sample dissolution was subjected to a thenoyltrifluoroacetone (TTA) separation. An aliquot of the sample dissolution was initially spiked with a ${ }^{238} \mathrm{Pu}$ tracer. A second aliquot of straight sample dissolution was analyzed along with the spiked sample. In addition, a third aliquot was used for determining the ${ }^{241} \mathrm{Pu}$ concentration. All of the plutonium in the samples was reduced once using hydroxylamine. An anion complexing reagent (aluminum nitrate) was then added, and the solutions were oxidized with 4M sodium nitrite. The plutonium was then extracted from the matrix using a TTA solution. The TTA layer was mounted on a counting dish, the mount was then analyzed by alpha spectroscopy. A blank sample was run with the sample set.

The analysis results for the ${ }^{239 / 240} \mathrm{Pu}$ alpha peak were yielded using the ${ }^{238} \mathrm{Pu}$ recoveries from the ${ }^{238} \mathrm{Pu}$ traced sample separation. The ratio of the ${ }^{239 / 240} \mathrm{Pu}$ to the ${ }^{238} \mathrm{Pu}$ in the sample was obtained from the alpha spectroscopy analysis of the non-spiked sample. That ratio was applied to the determined ${ }^{239 / 240} \mathrm{Pu}$ value to determine the ${ }^{238} \mathrm{Pu}$ activity in the sample.

The sample aliquot dedicated to the ${ }^{241} \mathrm{Pu}$ analysis was added to liquid scintillation cocktail following the separation and analyzed for both ${ }^{241} \mathrm{Pu}$ and gross $\mathrm{Pu}$-alpha constituents. The ratio of ${ }^{241} \mathrm{Pu}$ to total $\mathrm{Pu}$ alpha was determined and applied to the results from the plates in order to determine a ${ }^{241} \mathrm{Pu}$ concentration. 


\section{$8.16{ }^{129}$ I ANALYSIS}

An aliquot of each sample was spiked with stable iodide, was Cs-stripped using AMP-1 resin, and was subjected to a silver iodide precipitation method to separate any iodide in the matrix from other radionuclides. A blank DI water sample was analyzed along with the batch. The precipitates were analyzed for ${ }^{129}$ I activity with a low energy HPGe gamma spectroscopy detector. After the gamma analyses, the precipitates were analyzed by neutron activation analysis (NAA) to determine the levels of stable iodide carrier in the precipitates. The recoveries of the iodide carrier were used to correct the gamma spectroscopy results for the ${ }^{129} \mathrm{I}$ recoveries. Uncertainties provided are 1 sigma.

\subsection{Am/Cm ANALYSIS}

Aliquots of sample were run through an $\mathrm{Am} / \mathrm{Cm}$ separation procedure to separate the trivalent $\mathrm{Am} / \mathrm{Cm}$ isotopes from the higher valence state actinides following a sample oxidation step. Samples were run through the procedure in duplicate, one sample spiked with ${ }^{243} \mathrm{Am}$ for yielding purposes, one sample unspiked to correct for any ${ }^{243} \mathrm{Am}$ that may be present in the samples. The $\mathrm{Am} / \mathrm{Cm}$ sample mount was analyzed by alpha spectroscopy for ${ }^{244 / 243} \mathrm{Cm}$ and ${ }^{242} \mathrm{Cm}$ and by low energy gamma spectrometry for ${ }^{241} \mathrm{Am}$. The ${ }^{241} \mathrm{Am}$ activity in the samples was high enough to swamp out the ${ }^{243} \mathrm{Am}$ spikes' alpha spectrum, as a result, the alpha results of ${ }^{244} \mathrm{Cm} /{ }^{242} \mathrm{Cm}$ were quantified by ratioing their alpha peaks to that of the ${ }^{241} \mathrm{Am}$ which had been previously quantified in the gamma measurement. ${ }^{243} \mathrm{Am}$ values were quantified off a low energy gamma analysis of the mount containing no ${ }^{243} \mathrm{Am}$ spike, and using that ${ }^{243} \mathrm{Am} /{ }^{241} \mathrm{Am}$ ratio applied to the quantified ${ }^{241} \mathrm{Am}$ activity. A laboratory blank sample was run through all of the analyses with the batch of samples.

\subsection{8 ${ }^{14}$ C ANALYSIS}

Aliquots of sample were wet-ashed with a sodium persulfate/silver nitrate oxidation in conjunction with concentrated sulfuric acid. The carbon dioxide emitted was absorbed with Packard Instruments Carbosorb E. The Carbosorb E was then slurried into Ultima Gold AB, and analyzed by liquid scintillation analysis for ${ }^{14} \mathrm{C}$. Each sample was run through the process in duplicate. A blank solution, spiked with a ${ }^{14} \mathrm{C}$ standard, was run (in duplicate) in parallel with the samples to determine ${ }^{14} \mathrm{C}$ recoveries. The average recoveries were applied to the sample results to quantify the ${ }^{14} \mathrm{C}$ concentrations. A second blank solution, spiked with the ${ }^{14} \mathrm{C}$ standard was also run in duplicate through the process to serve as the laboratory control sample. One customer sample was spiked with some ${ }^{14} \mathrm{C}$ (again in duplicate) and run through the process to serve as the matrix spike. A blank solution was also run through the entire process to ensure no cross contamination existed at the laboratory level. 


\subsection{9 ${ }^{59} \mathrm{Ni}$ ANALYSIS}

Aliquots of aqueous sample were spiked with nickel carrier and then concentrated. The treated sample aliquots were then subjected to a Ni-DMG separation. Aliquots of the resulting separated nickel solution were analyzed by liquid scintillation to determine ${ }^{63} \mathrm{Ni}$, $\mathrm{x}$-ray spectroscopy to determine ${ }^{59} \mathrm{Ni}$, and ICP-ES to determine the concentrations of nickel carrier recovered. The concentrations of nickel carrier recovered were used to yield the ${ }^{59} \mathrm{Ni}$ and ${ }^{63} \mathrm{Ni}$ measurements. A laboratory blank was also run through the process. 
WSRC-TR-2003-00210, REVISION 0

SRT-RPP-2003-00091, REVISION 0

This page intentionally left blank. 


\subsection{REFERENCES}

1. Arakali, A., Tank 241-AN-107 Sample Compositing, Homogenization and Analyses Test Specification 24590-WTP-TSP-RT-02-010, Rev. 0, June 03, 2002

2. Martin, K., Task Technical and Quality Assurance Plan for Compositing, Homogenizing, and Characterizing Samples from Hanford Tank 241-AN-107, WSRC-TR-2002-00185, Revision 1, August 12, 2002, Westinghouse Savannah River Company, Aiken, SC.

3. Hay, M. S., Edwards, T. B., "Statistical Analysis of ESP Verification Test Samples," WSRC-RP-94-1224, November 4, 1994, Westinghouse Savannah River Company, Aiken, SC.

4. Smith, G. L., "Characterization of Analytical Reference Glass-1 (ARG-1)," PNL-8992, December 1993

5. Gregg J. Lumetta and F. Vaugh Hoopes., Washing of the AN-107 Entrained Solids. BNFL-RPT-007, Rev. 0., August 1999. Battelle Pacific Northwest Division, Richland, Washington. 
WSRC-TR-2003-00210, REVISION 0

SRT-RPP-2003-00091, REVISION 0

This page intentionally left blank. 


\section{APPENDIX A. CHAIN OF CUSTODY DOCUMENTATION}

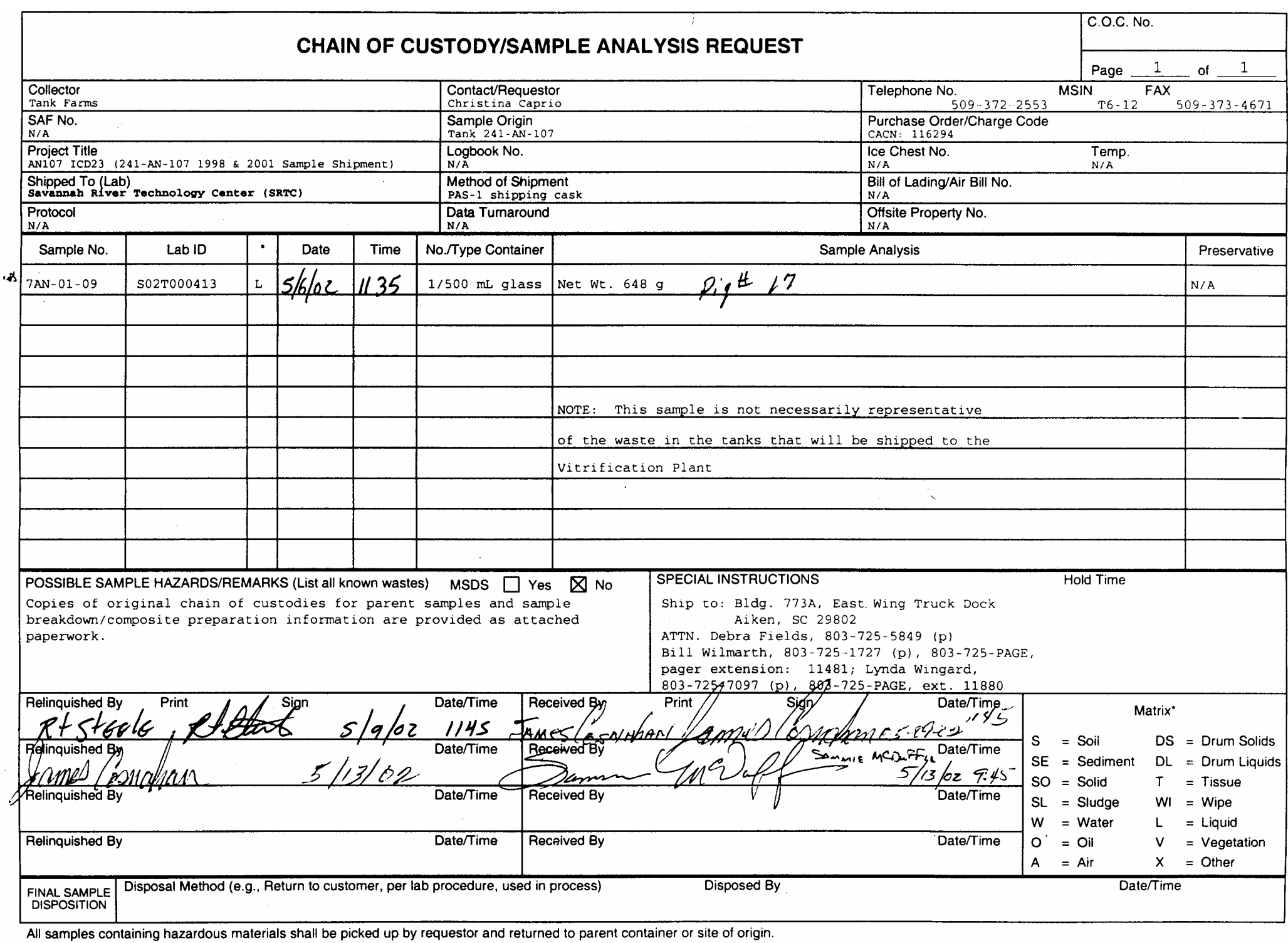




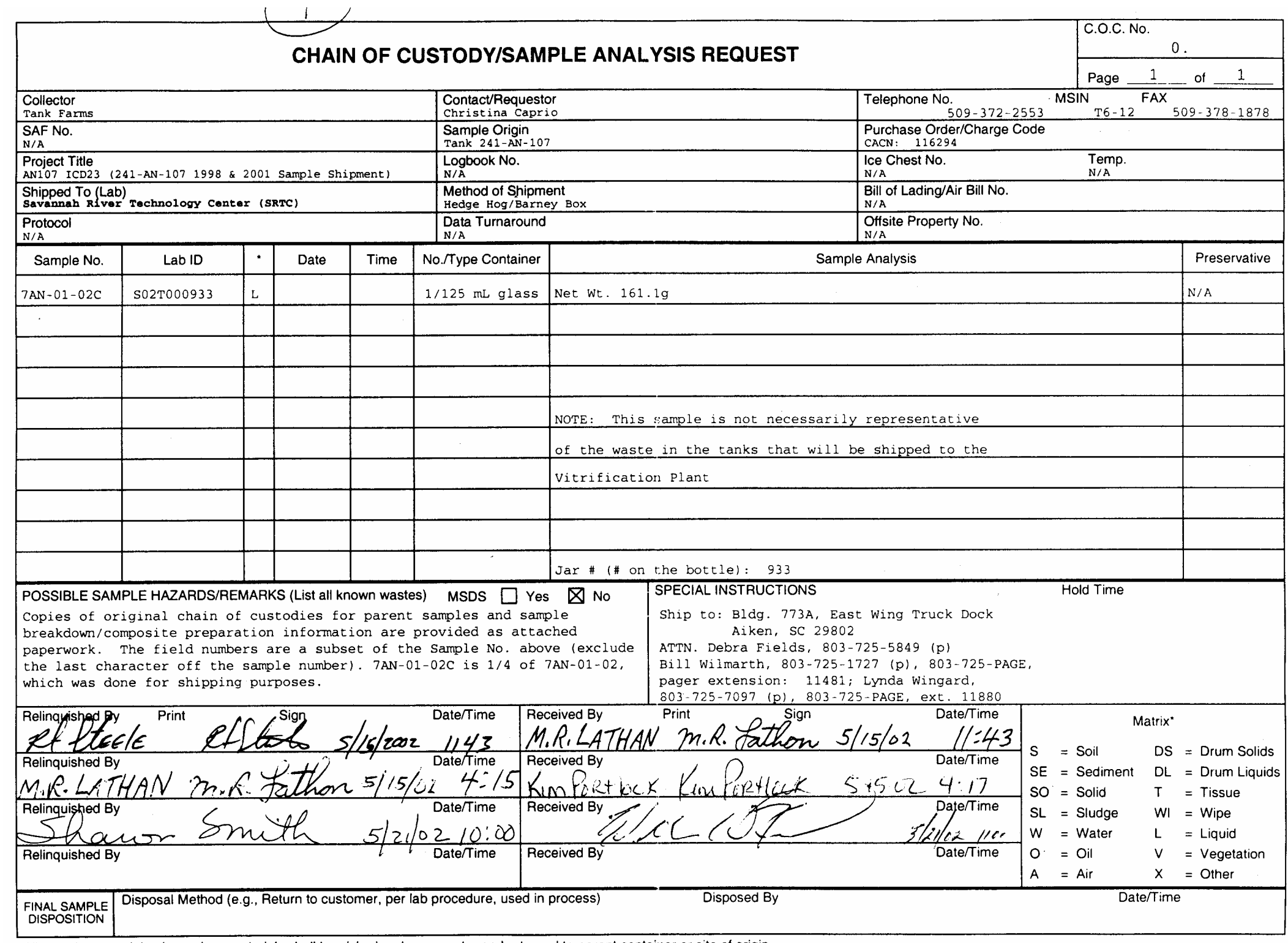

All samples containing hazardous materials shall be picked up by requestor and returned to parent container or site of origin.

DISTRIBUTION: White - Remain with Samples Color - Customer 


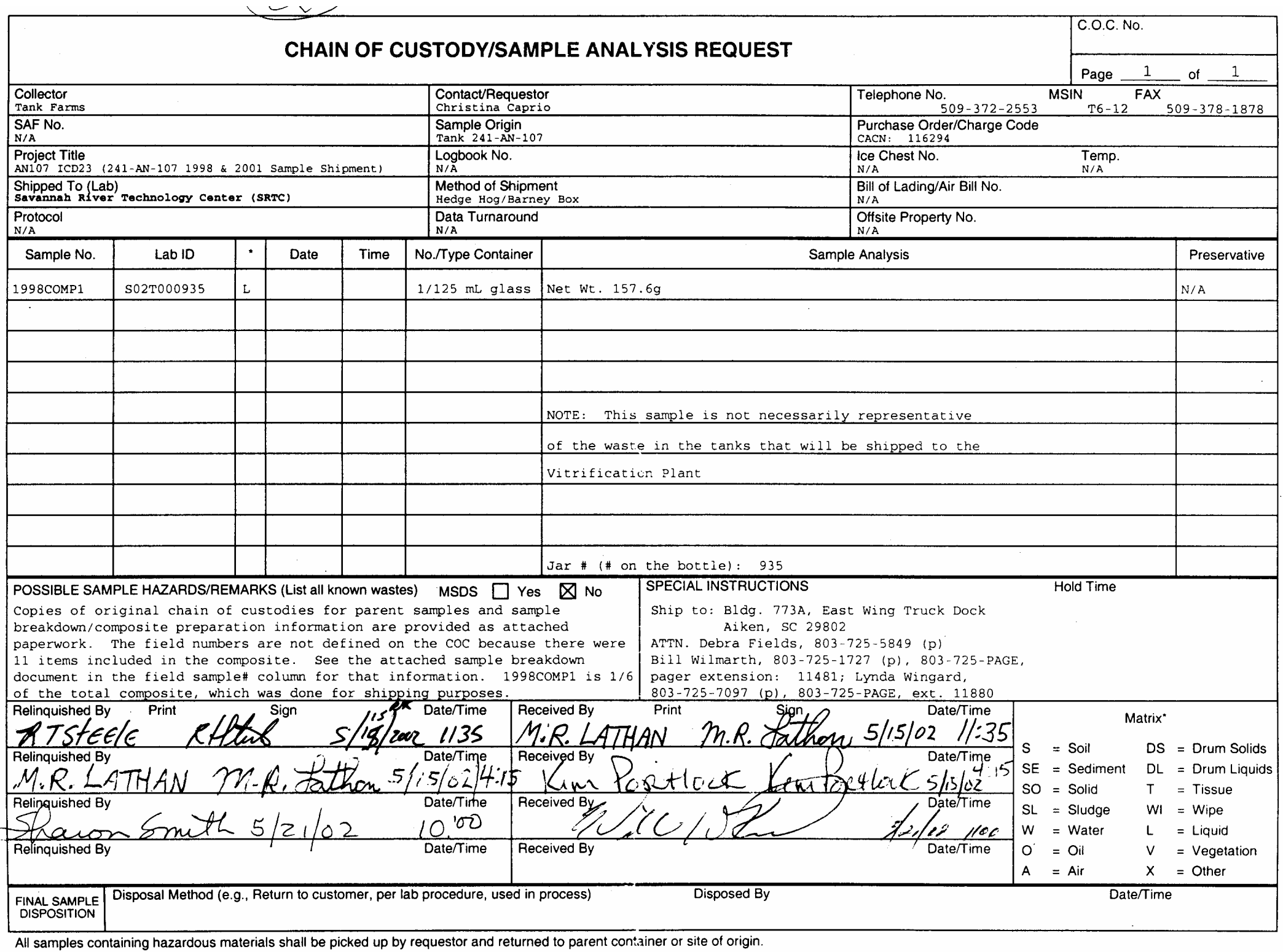




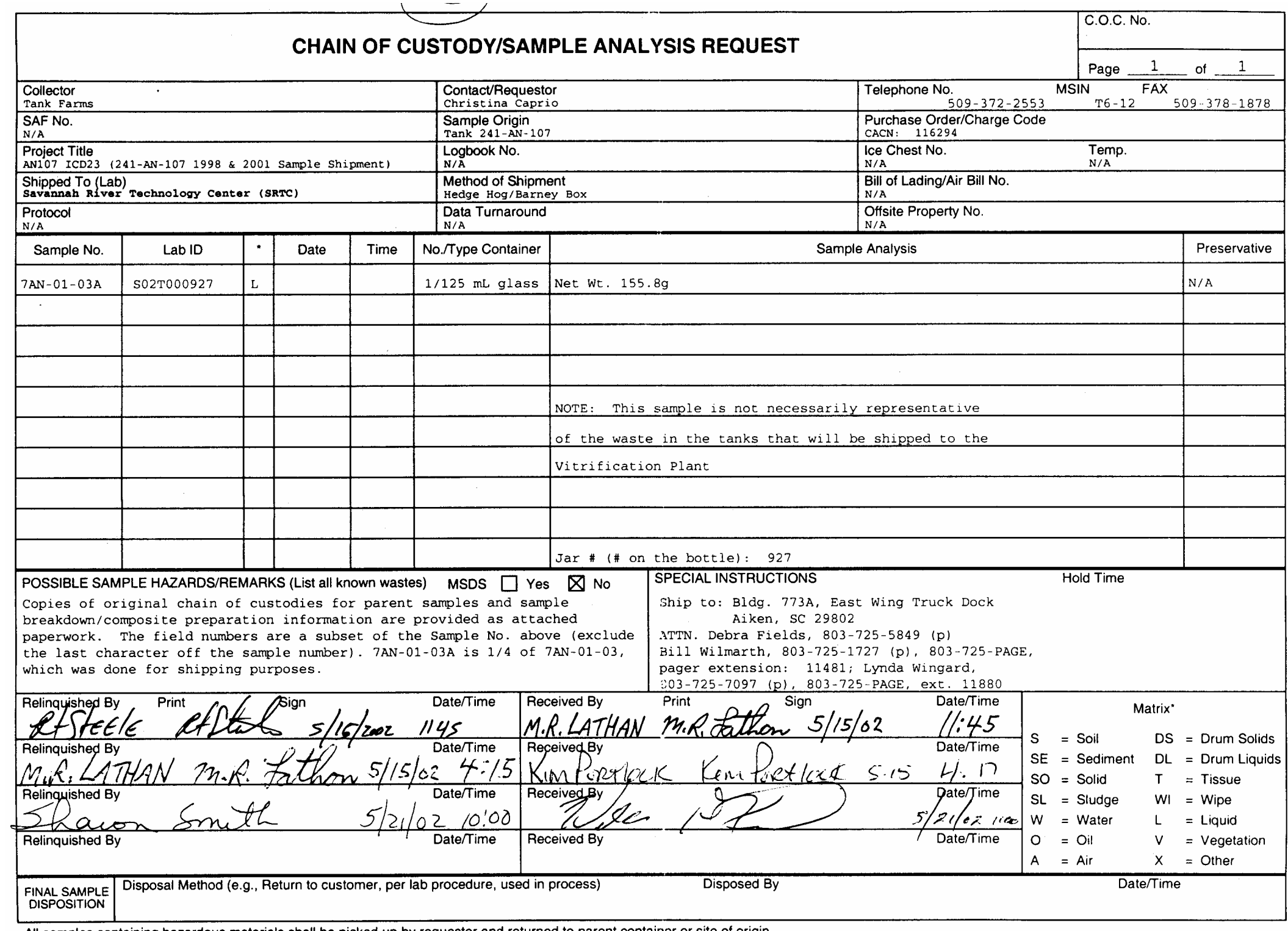

All samples containing hazardous materials shall be picked up by requestor and returned to parent container or site of origin. 


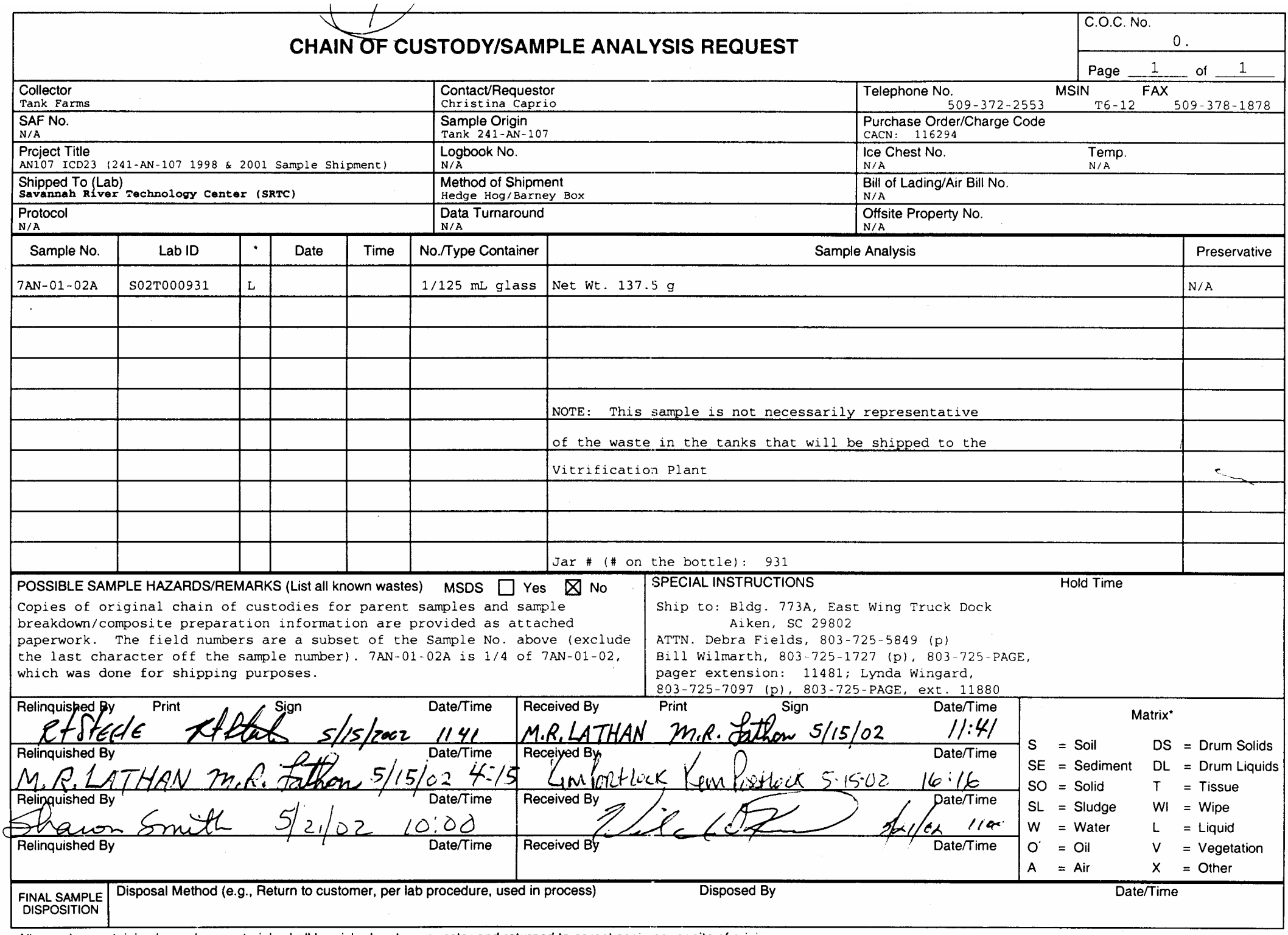

All samples containing hazardous materials shall be picked up by requestor and returned to parent corricin

DISTRIBUTION: White - Remain with Samples Color-Customer 


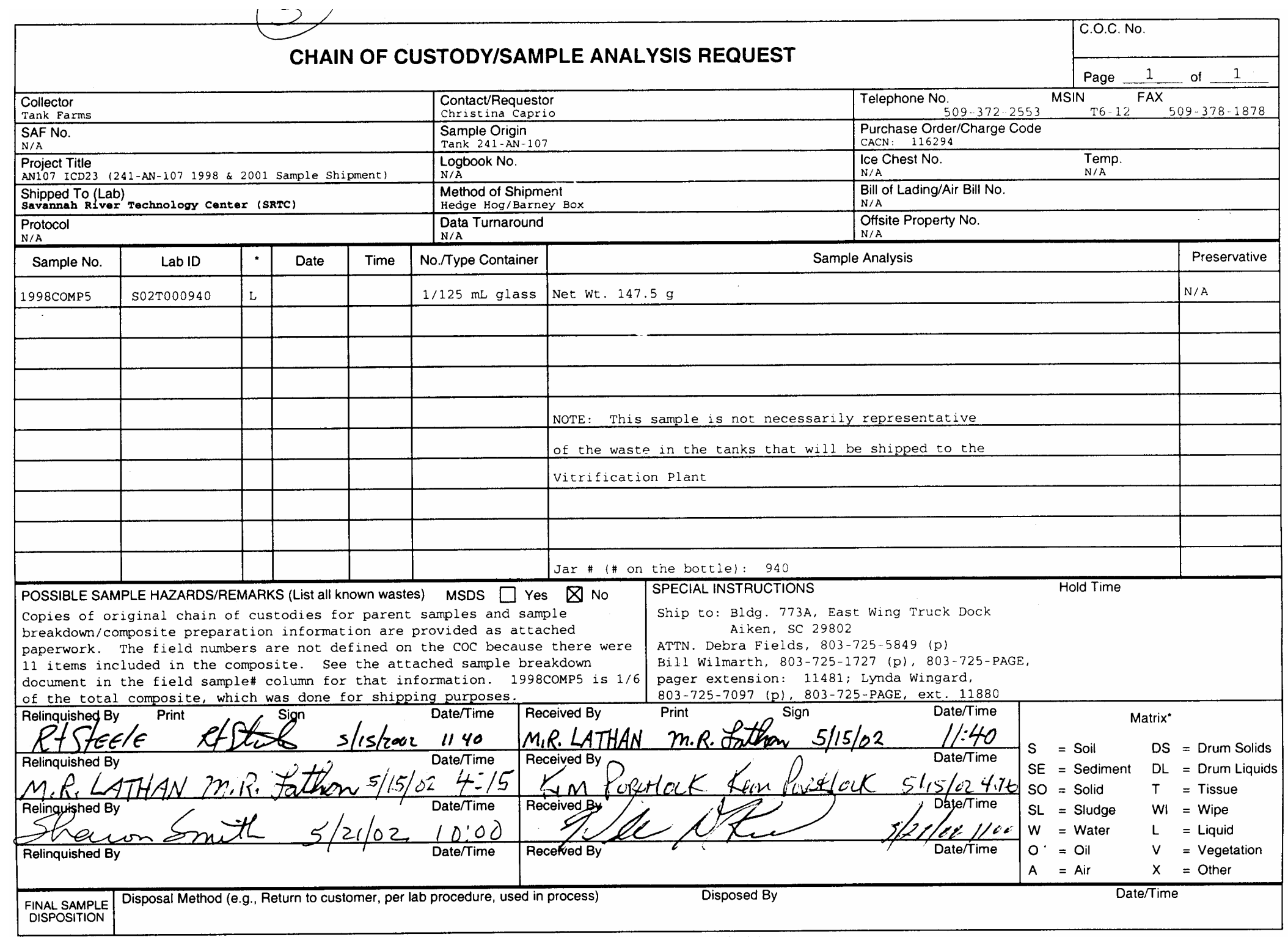

All samples containing hazardous materials shall be picked up by requestor and returned to parent container or site of origin.

DISTRIBUTION: White - Remain with Samples Color - Customer 


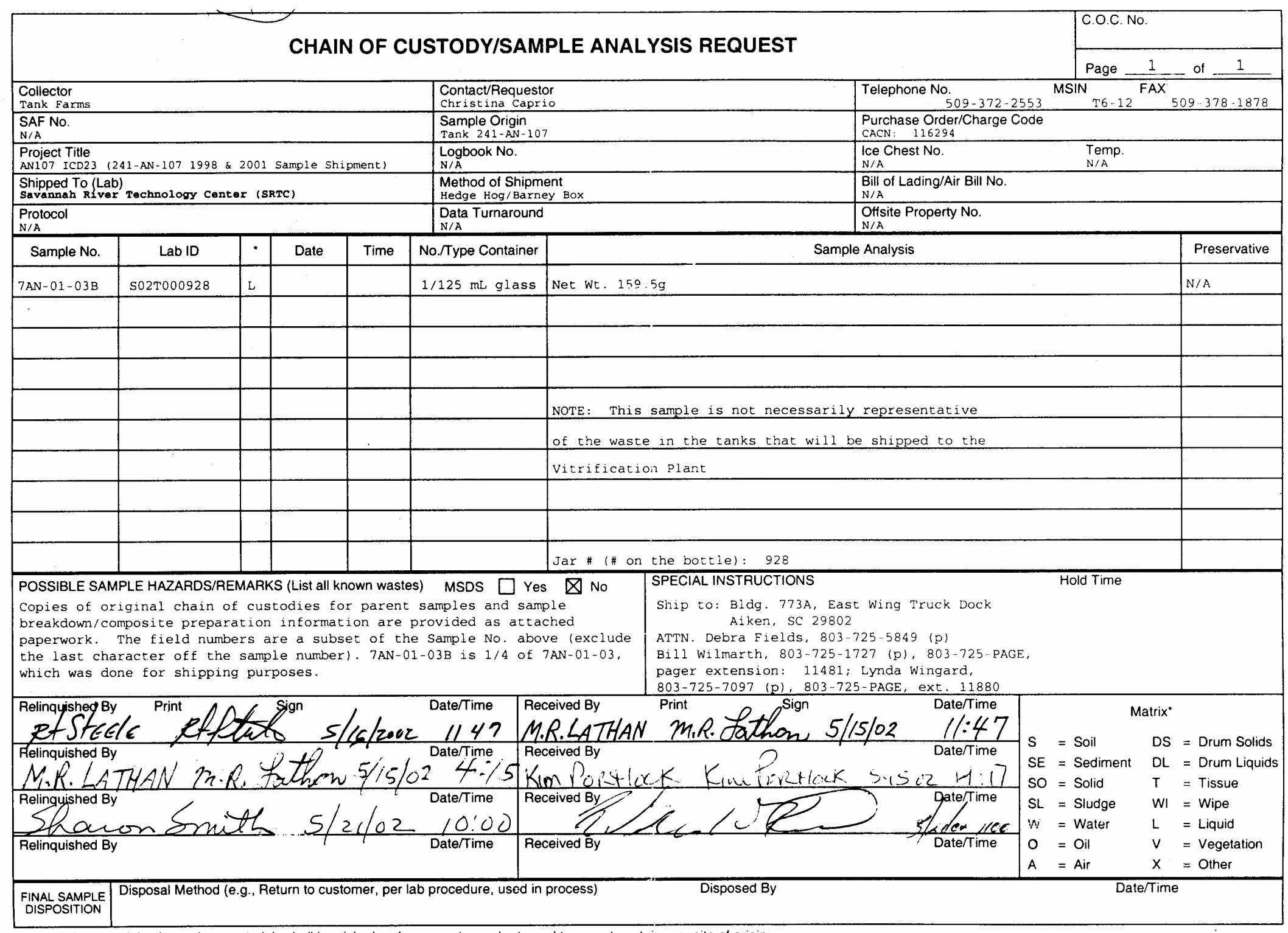




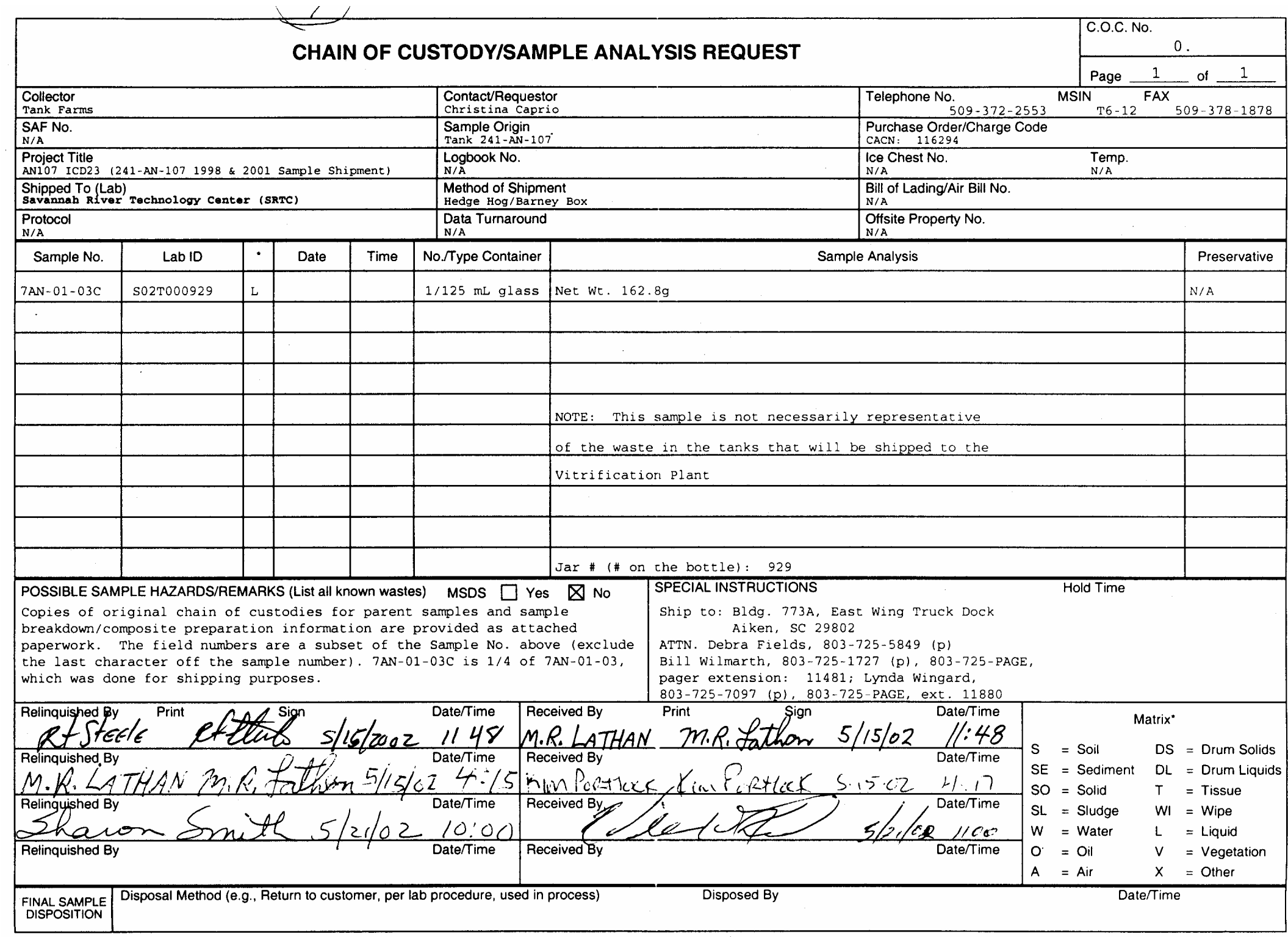

All samples containing hazardous materials shall be picked up by requestor and returned to parent container or site of origin.

DISTRIBUTION: White - Remain with Samples Color - Customer 


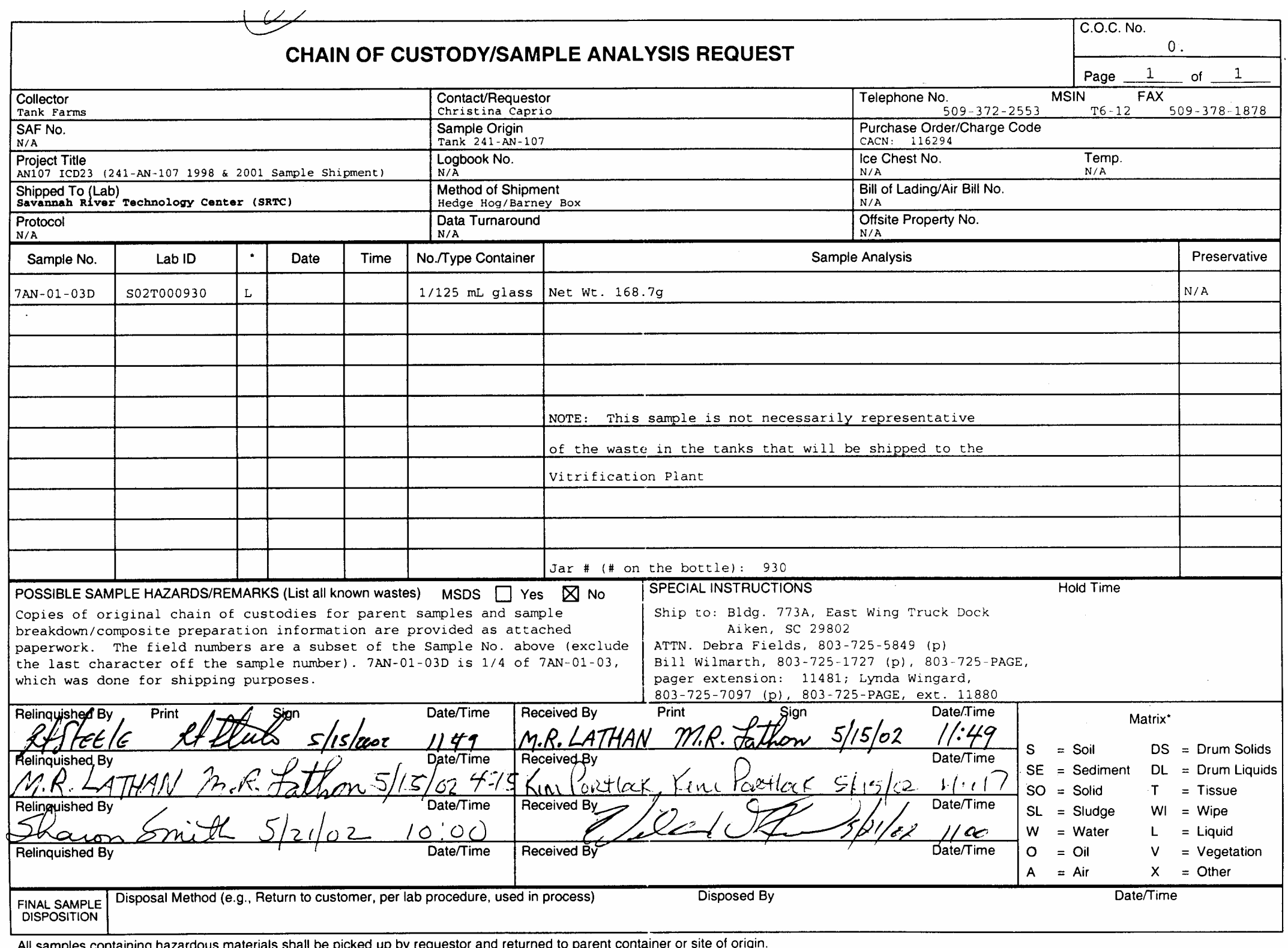

All samples containing hazardous materials shall be picked up by requestor and returned to parent container or site of origin.

DISTRIBUTION: White - Remain with Samples Color-Customer 


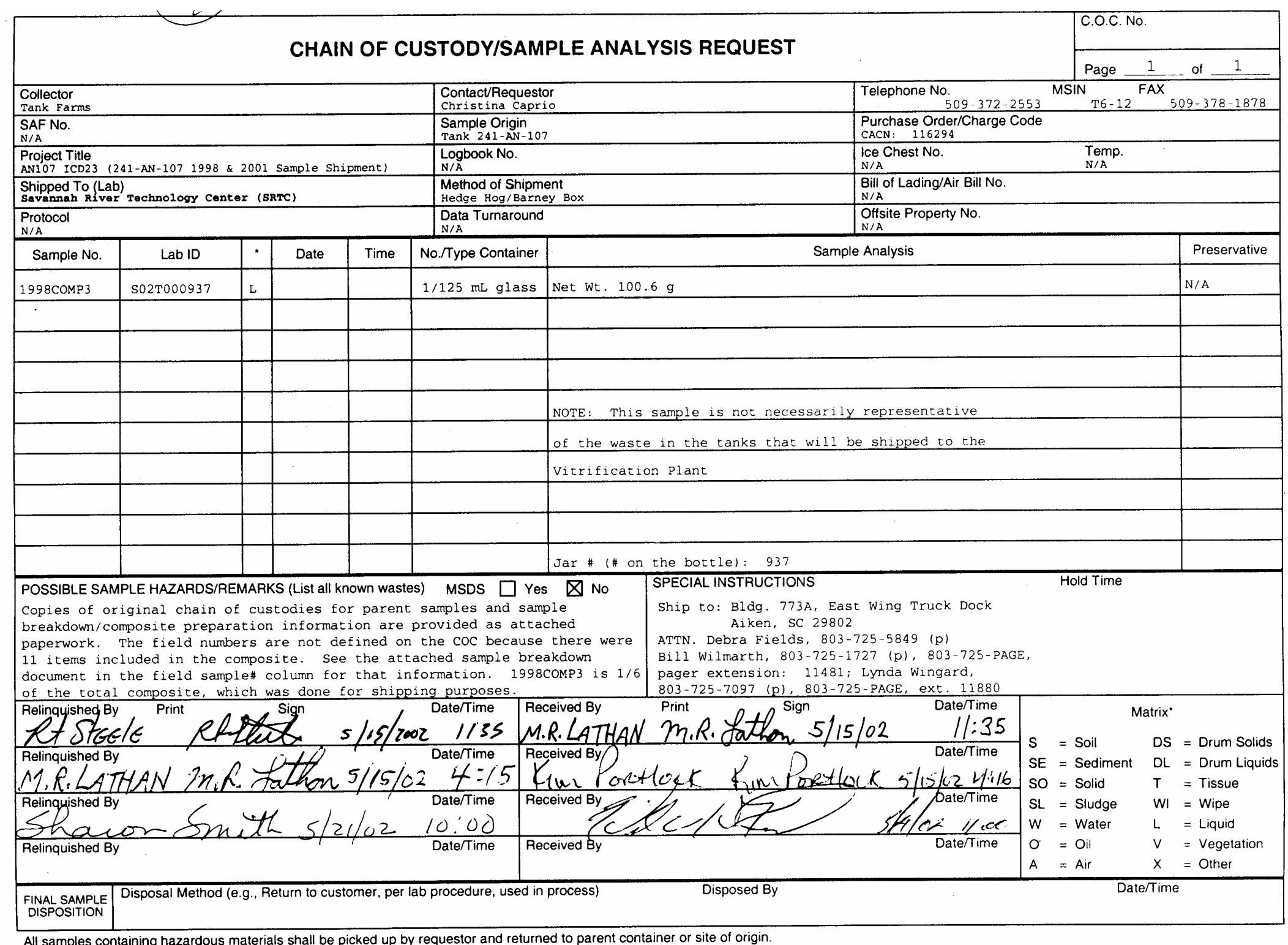

All samples containing hazardous materials shall be picked up by requestor and returned to parent container or site of origin 


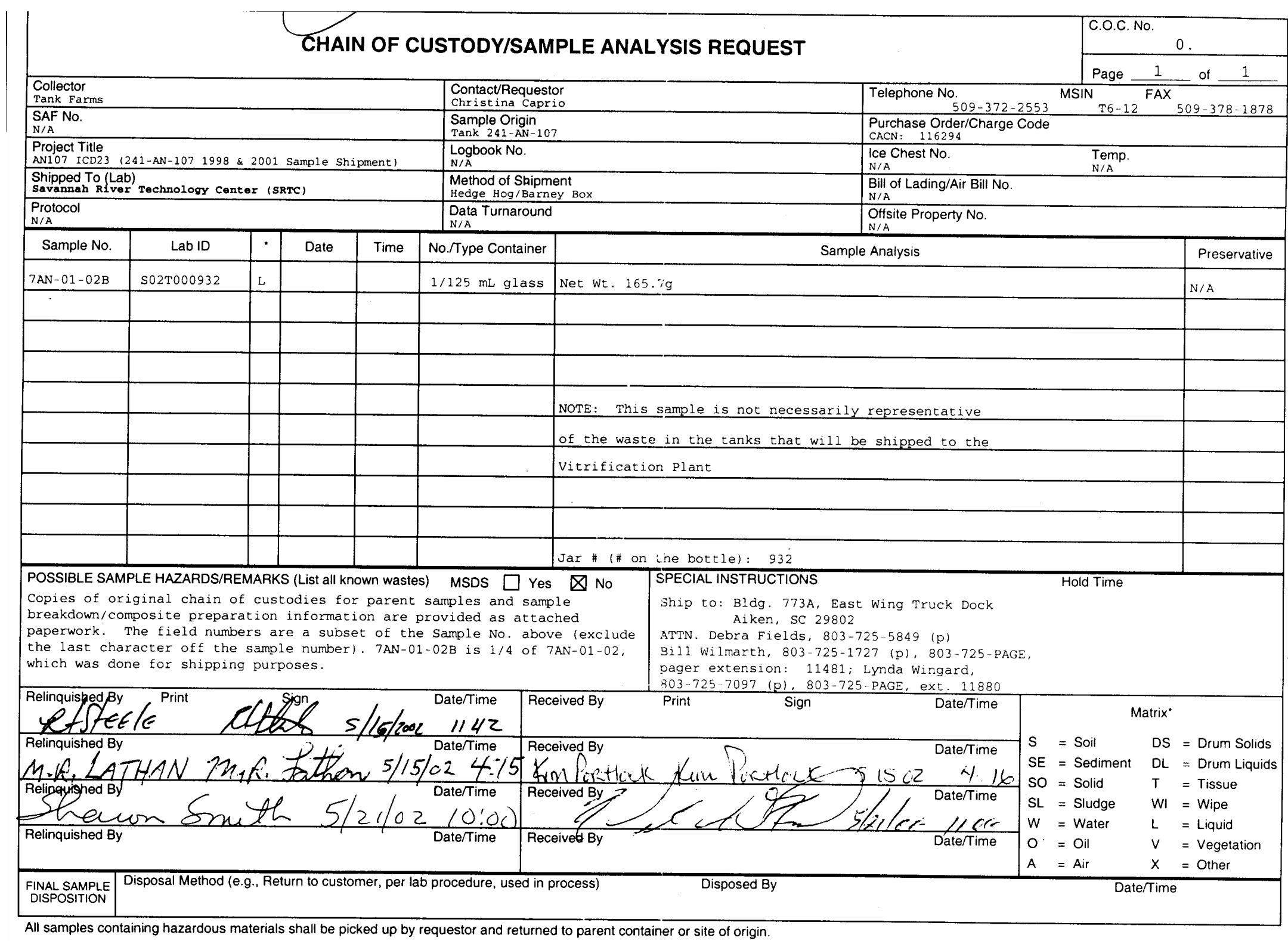




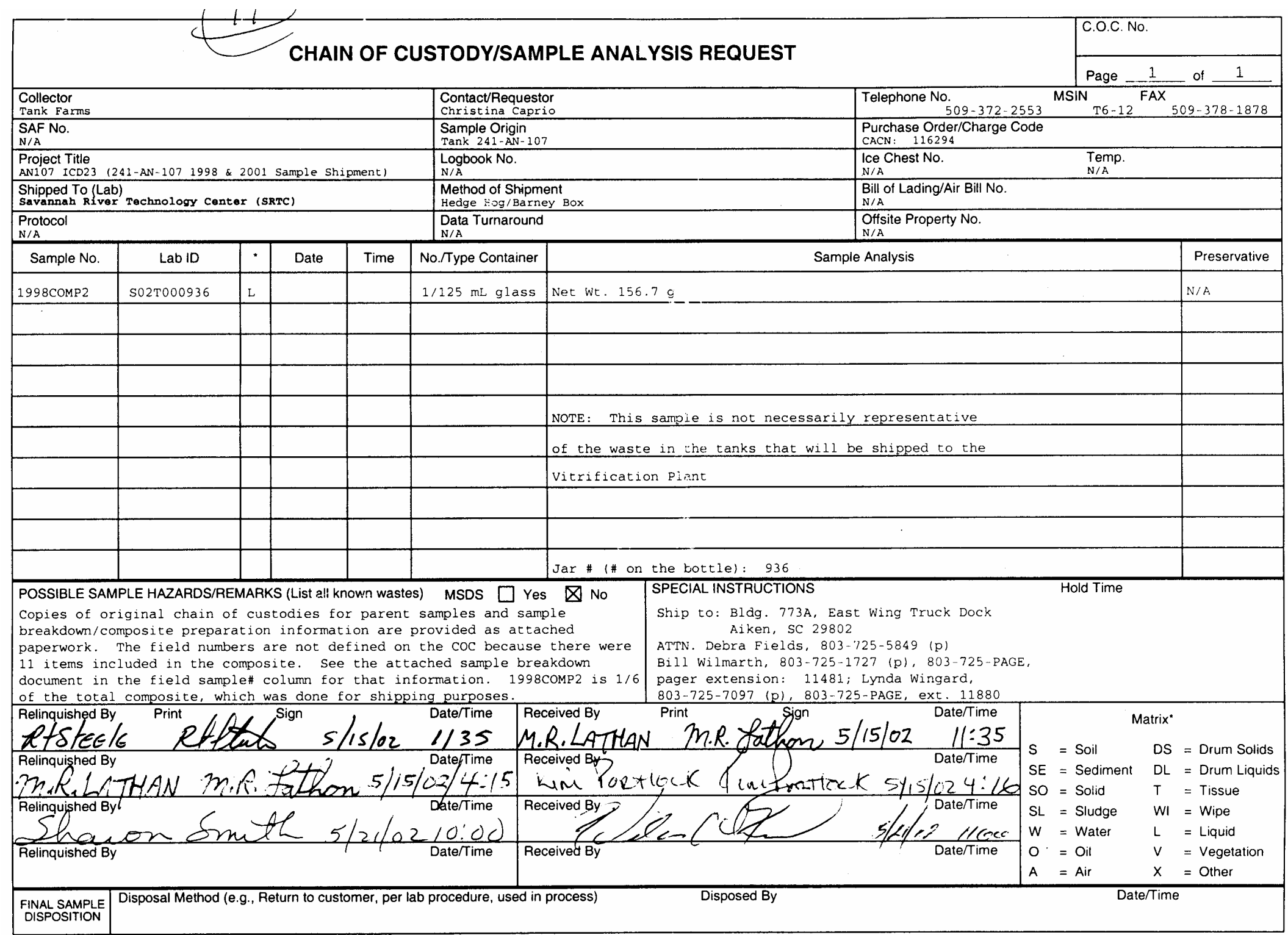

All samples containing hazardous materials shall be picked up by requestor and returned to parent container or site of origin.

DISTRIBUTION: White - Remain with Samples Color - Customer 


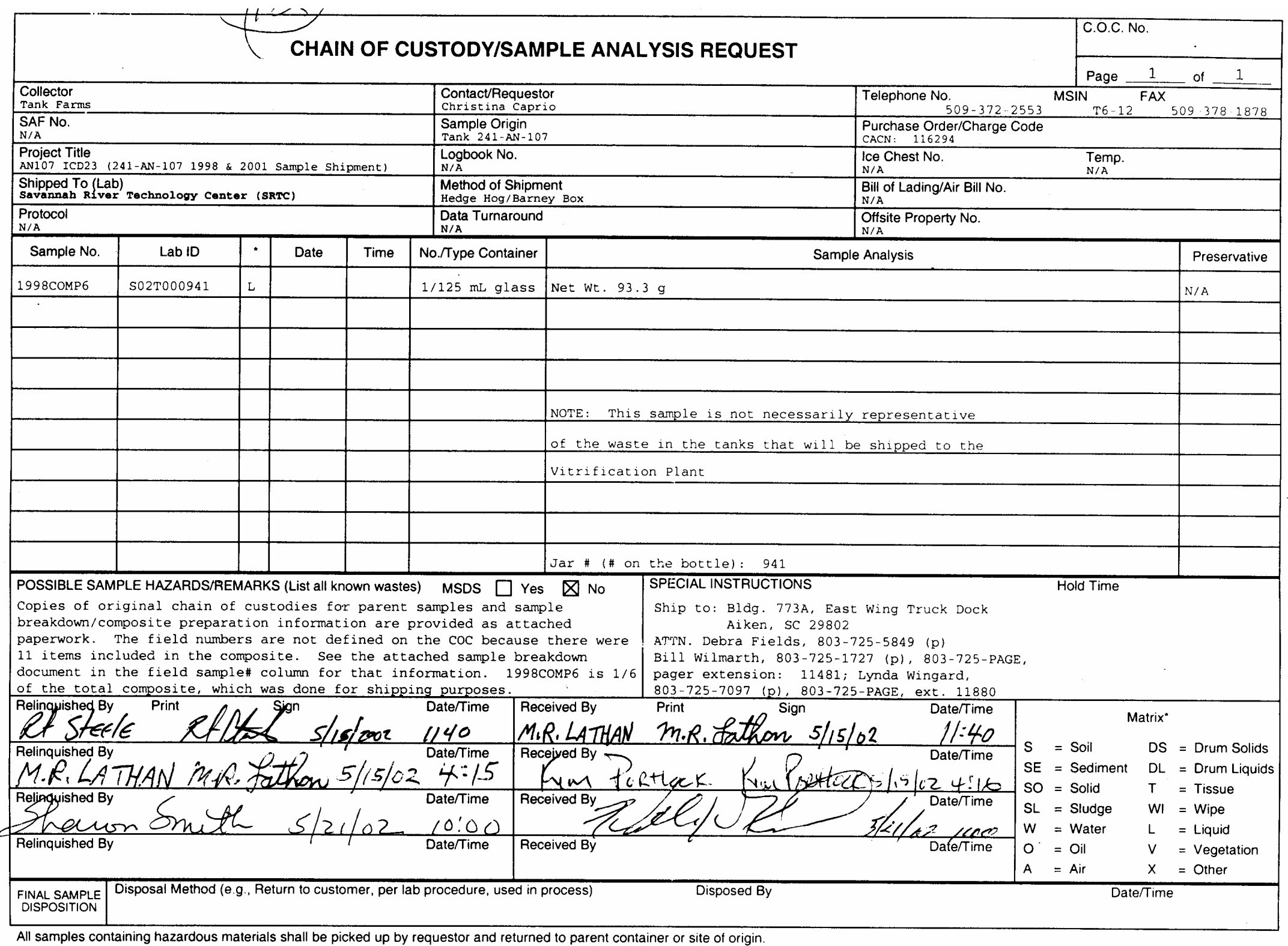

All samples containing hazardous materials shall be picked up by requestor and returned to parent container or site of origin 


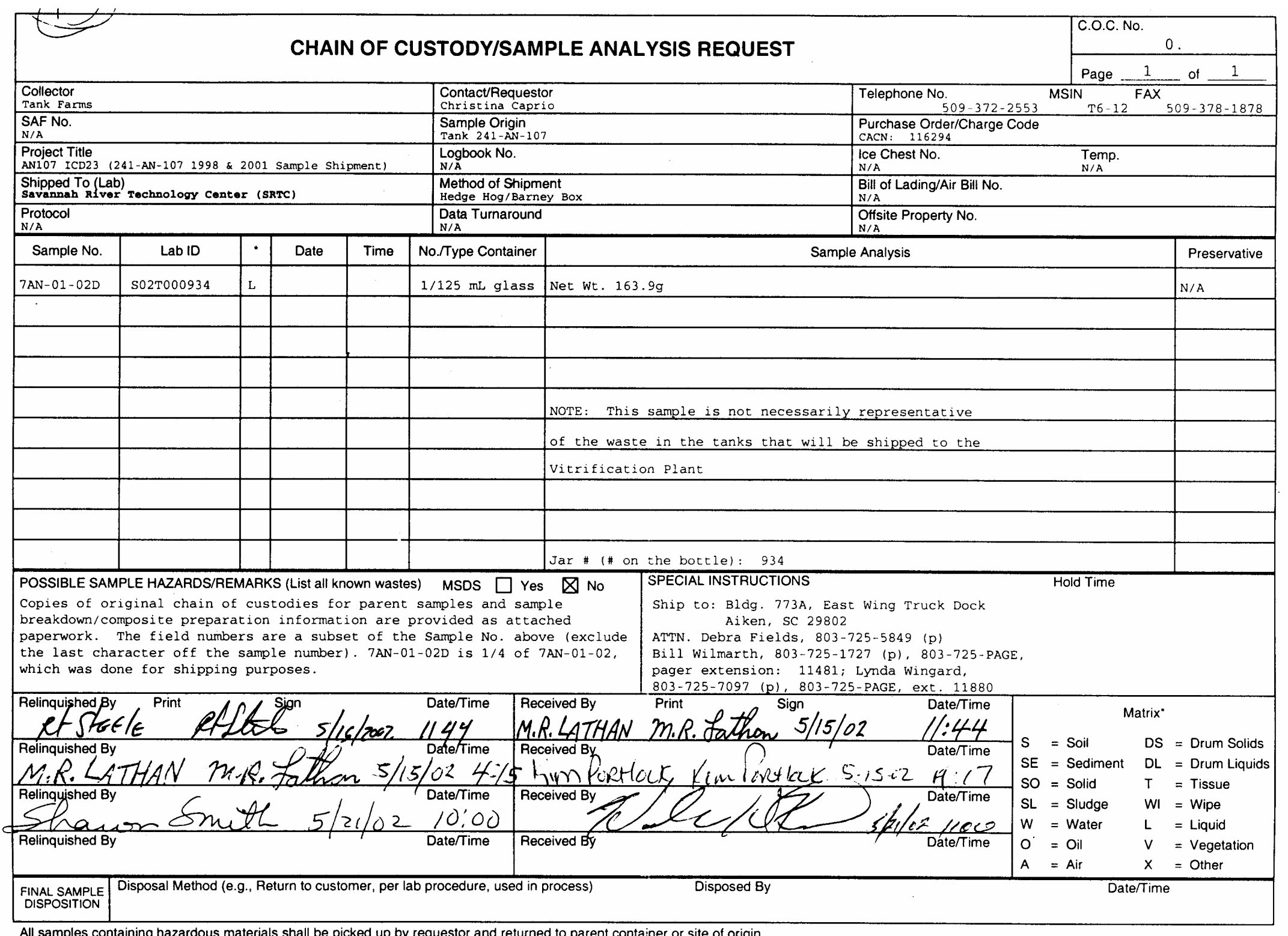

All samples containing hazardous materials shall be picked up by requestor and returned to parent container or site of origin

DISTRIBUTION: White - Remain with Samples Color - Customer 


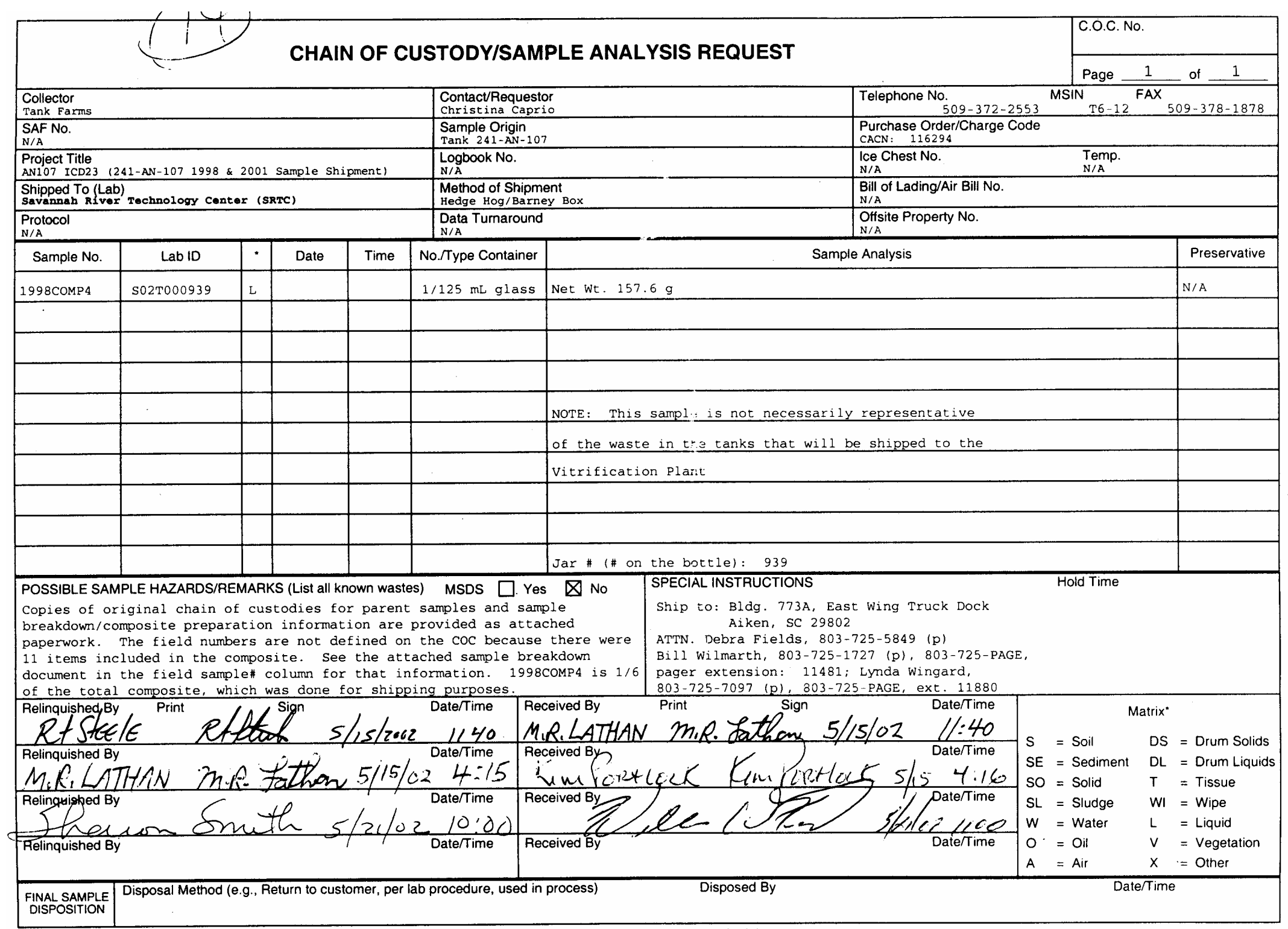

All samples containing hazardous materials shall be picked up by requestor and returned to parent container or site of origin.

DISTRIBUTION: White - Remain with Samples Color - Customer 
This page intentionally left blank. 


\section{APPENDIX B. MICROGRAPHS OF AN-107 DRIED SOLIDS}

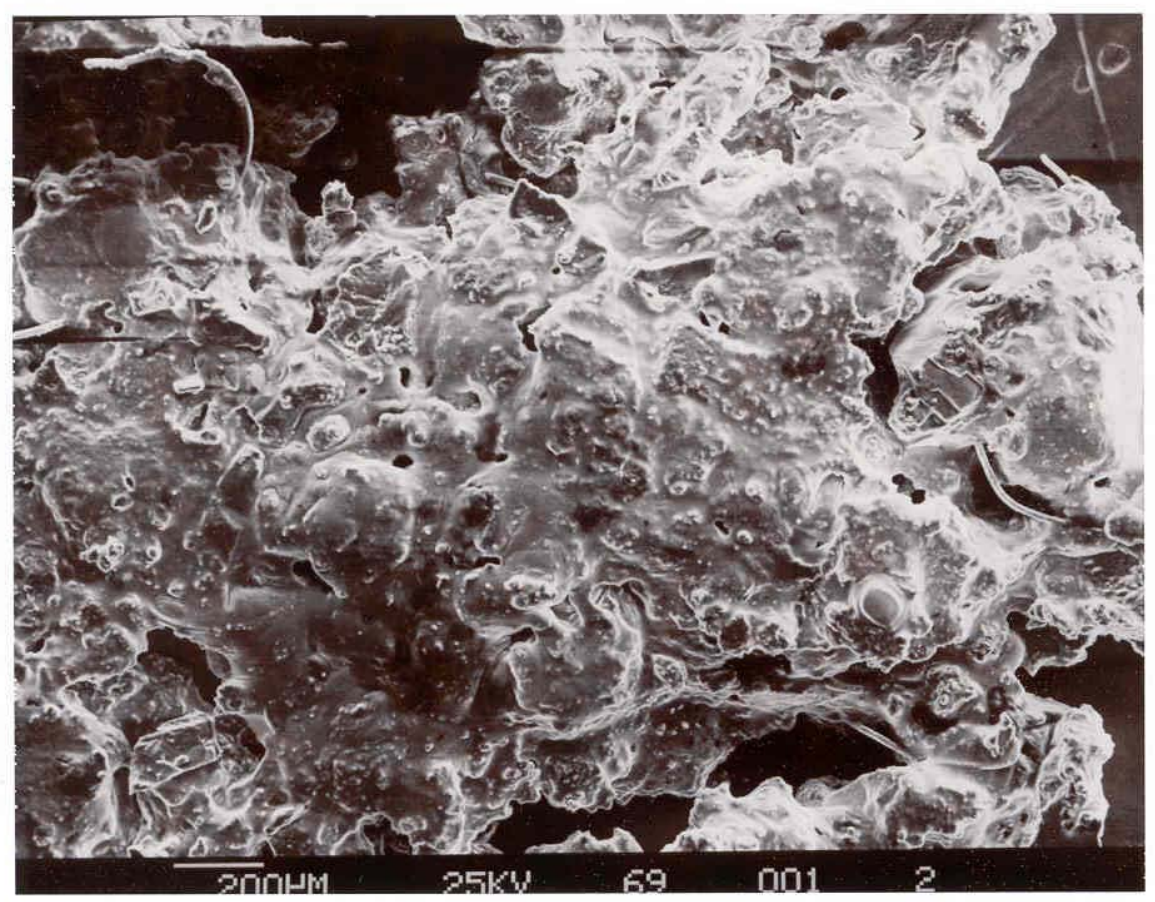

Figure B- 1. AN-107 Solid 1 50x Magnification

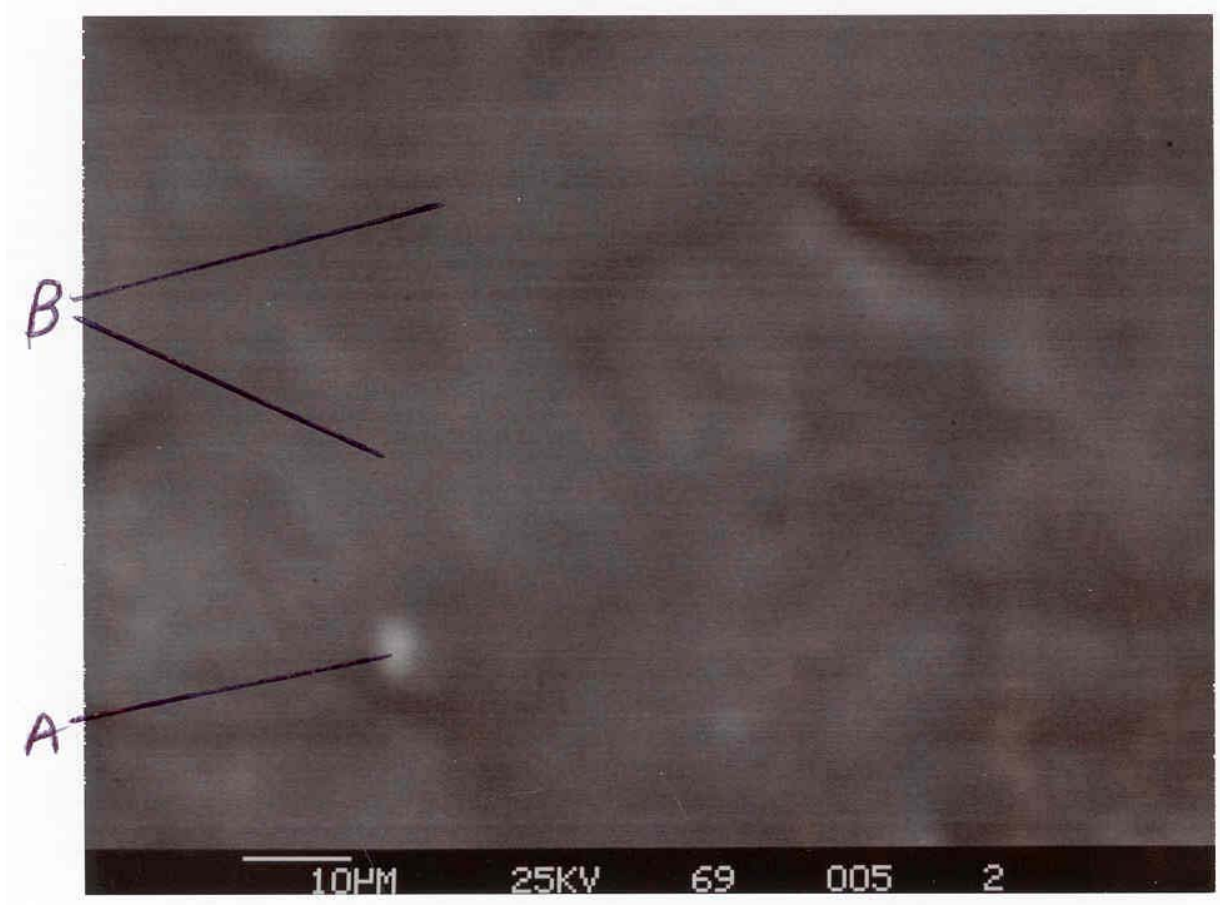

Figure B- 2. AN-107 Solid 1 1000x Magnification 
TN-5502 WSRC CSEM.

MON 30-SEP-02 10:27

Cursor: 0.000keV $=0$

ROI (0) $0.040: 0.060=0 / \sec$

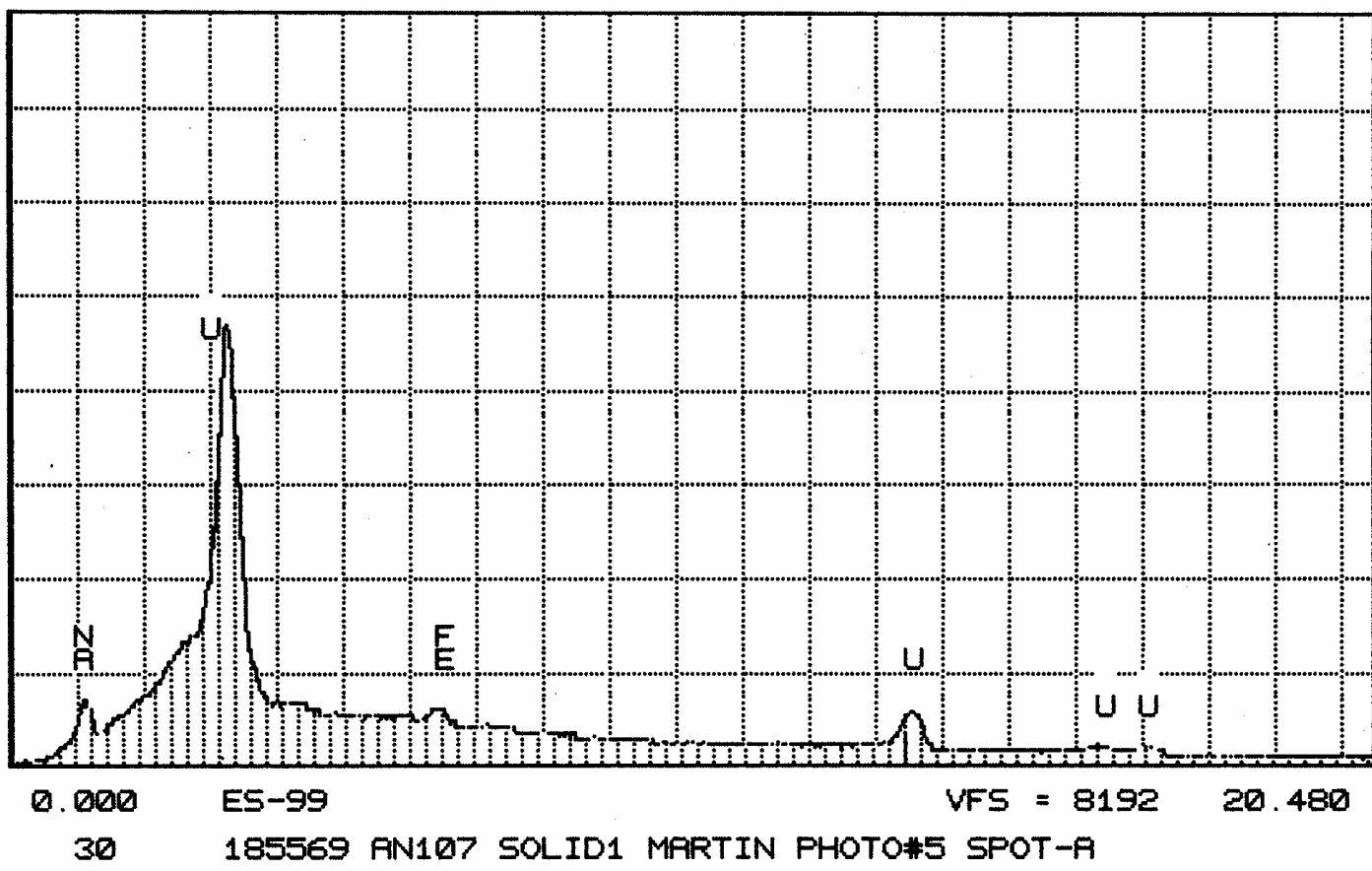

TN-5S02 WSRC CSEM.

Cursor: $0.000 \mathrm{keV}=0$

MON 30-SEP-02 10:33

ROI (0) $0.040: 0.060=0 / \sec$

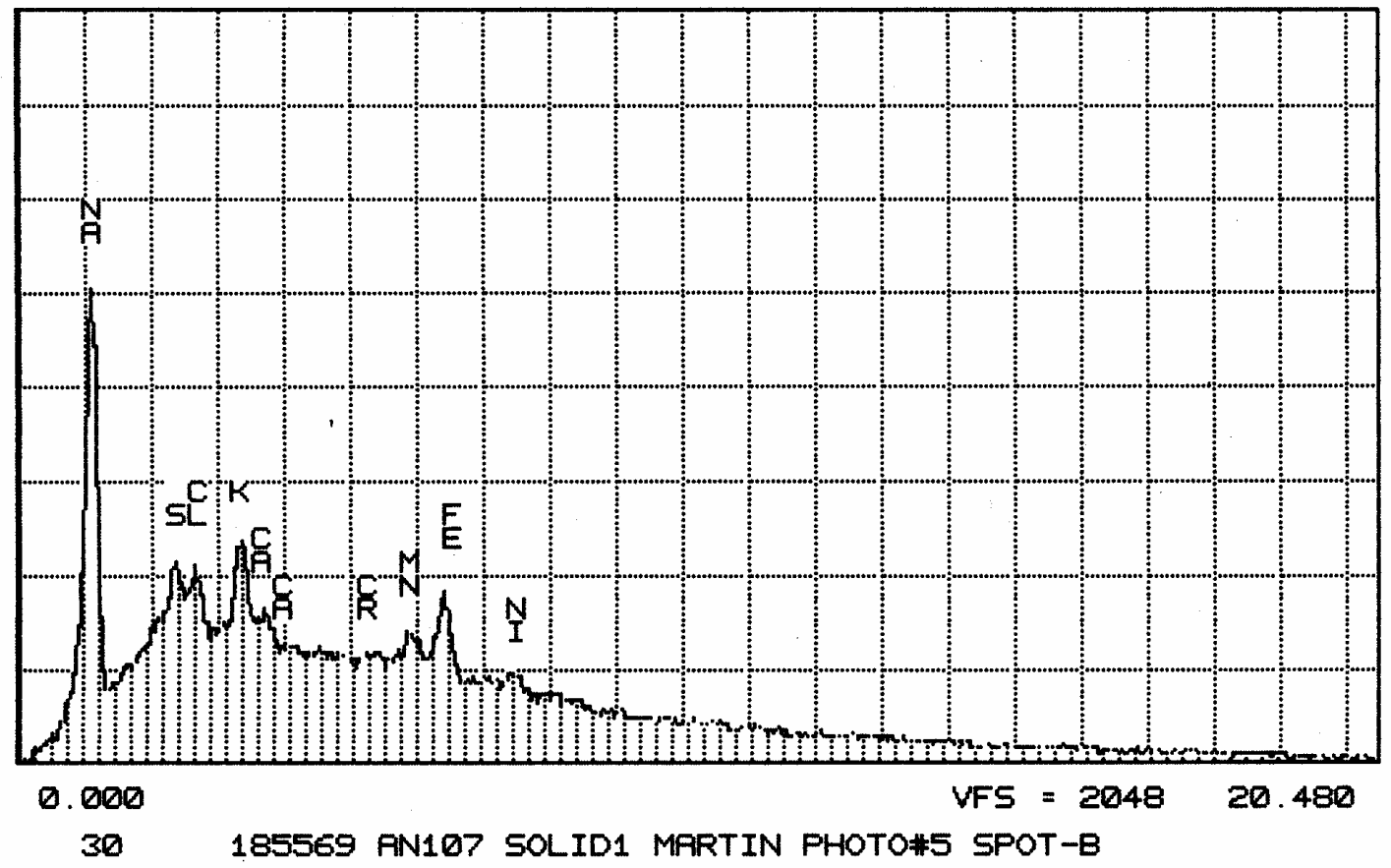

Figure B- 3. AN-107 Solid 1 Spot-A (top) and Spot-B (bottom) 


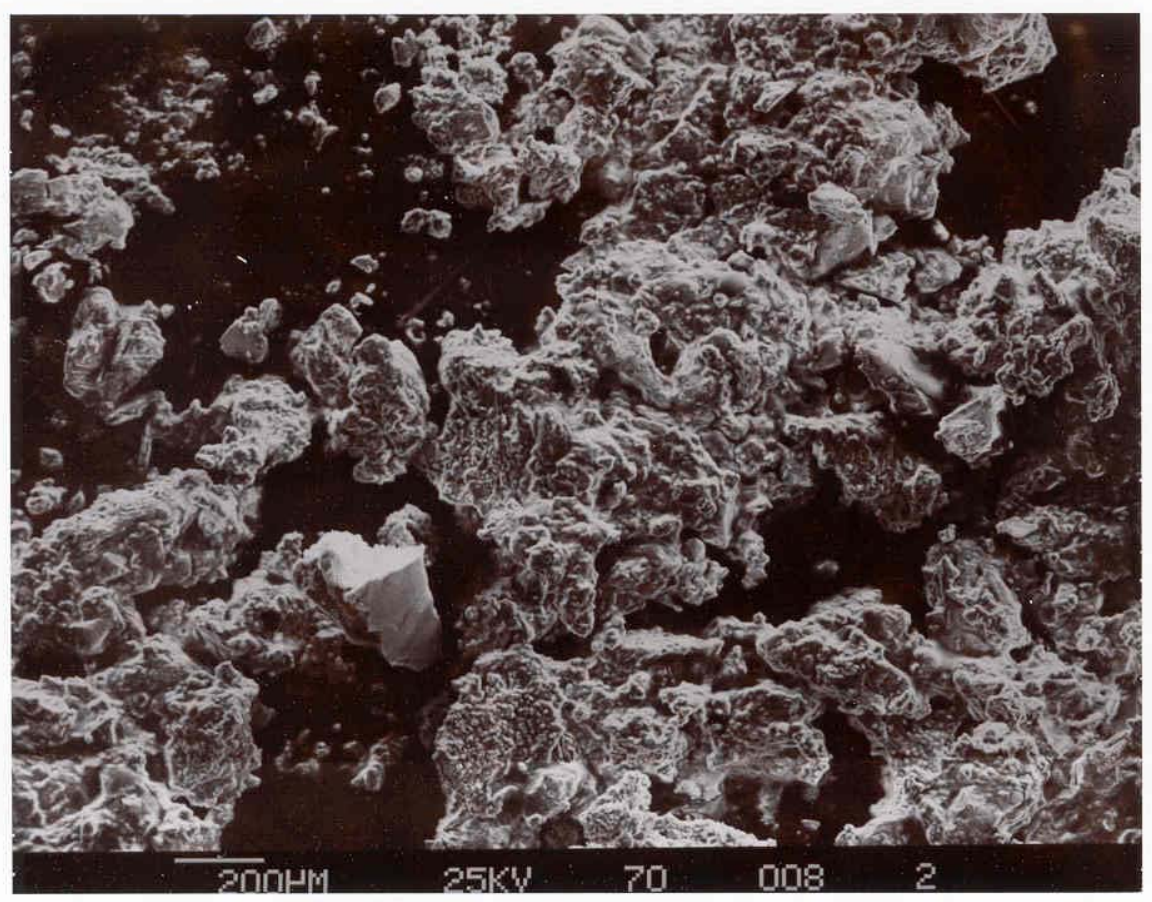

Figure B- 4. AN-107 Solid 2 50x Magnification

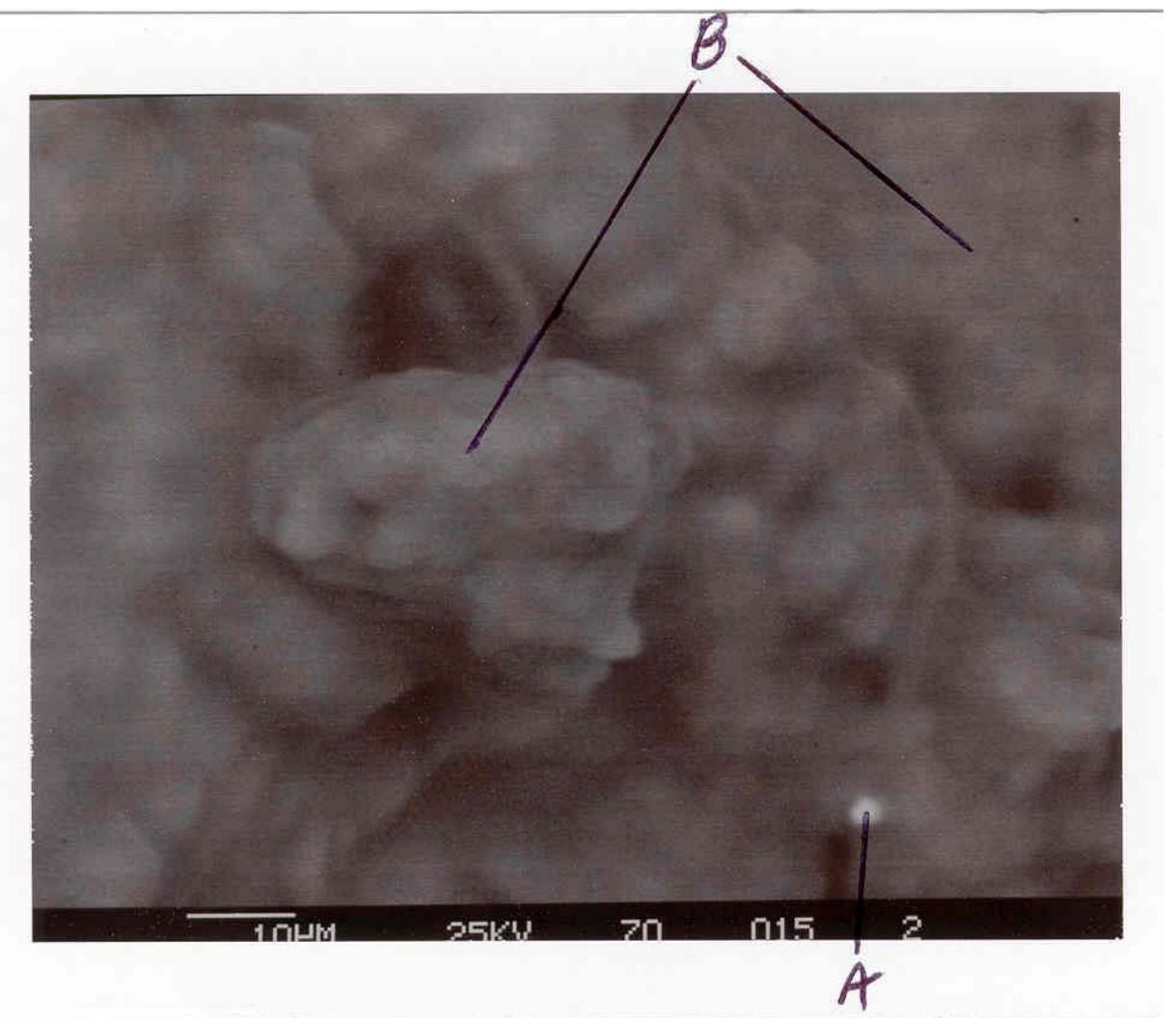

Figure B- 5. AN-107 Solid 2 1000x Magnification 
TN-5S02 WSRC CSEM.

MON 30-SEP-Q2 $14: 26$

Cursor: $0.000 \mathrm{keV}=0$

ROI

(0) $0.040: 0.060=0 / \sec$

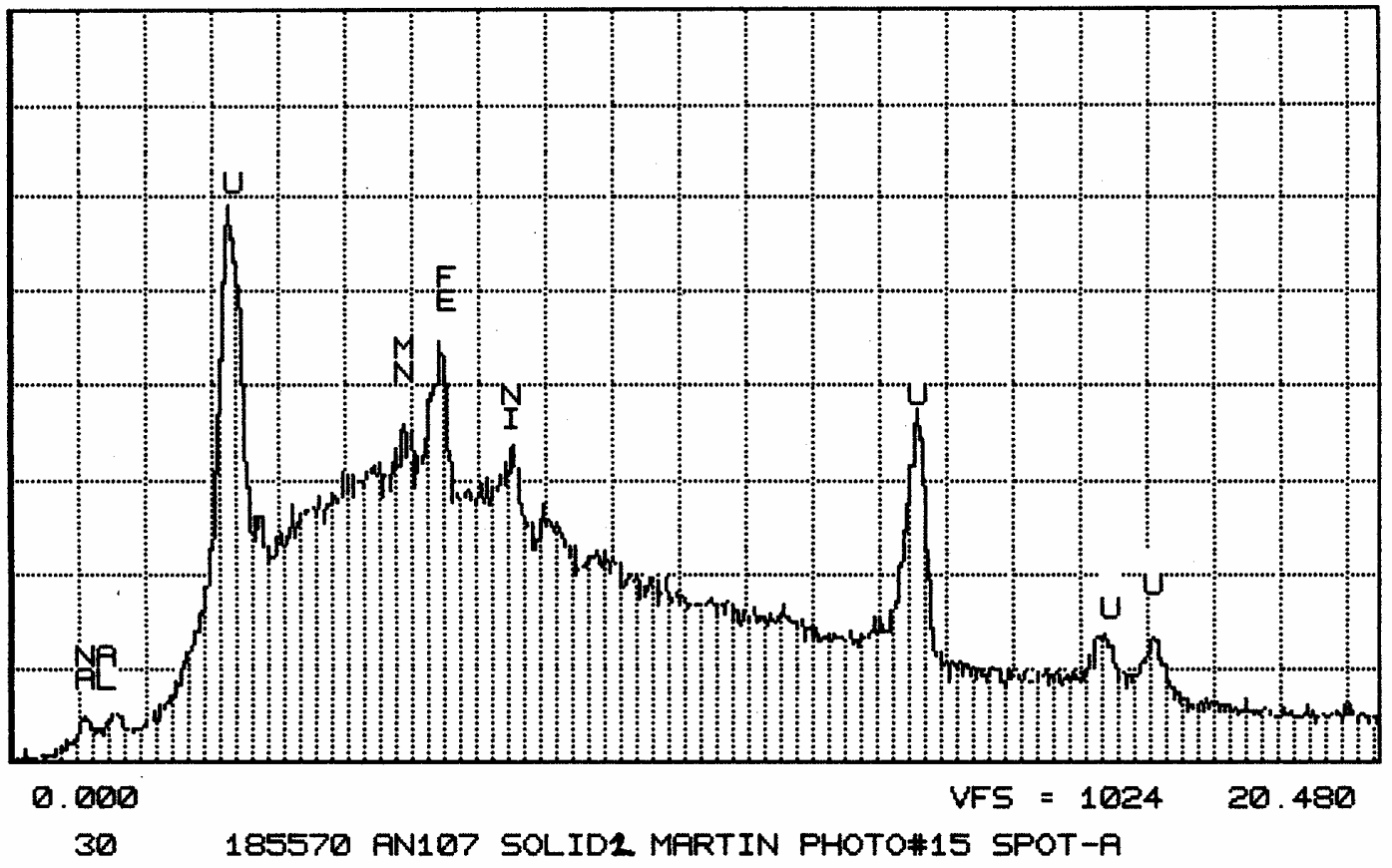

TN-5502 WSRC CSEM.

MON 30-SEP-Ø2 14:28

Cursor: $0.000 \mathrm{keV}=0$

ROI (0) 0.040:0.060=0/sec

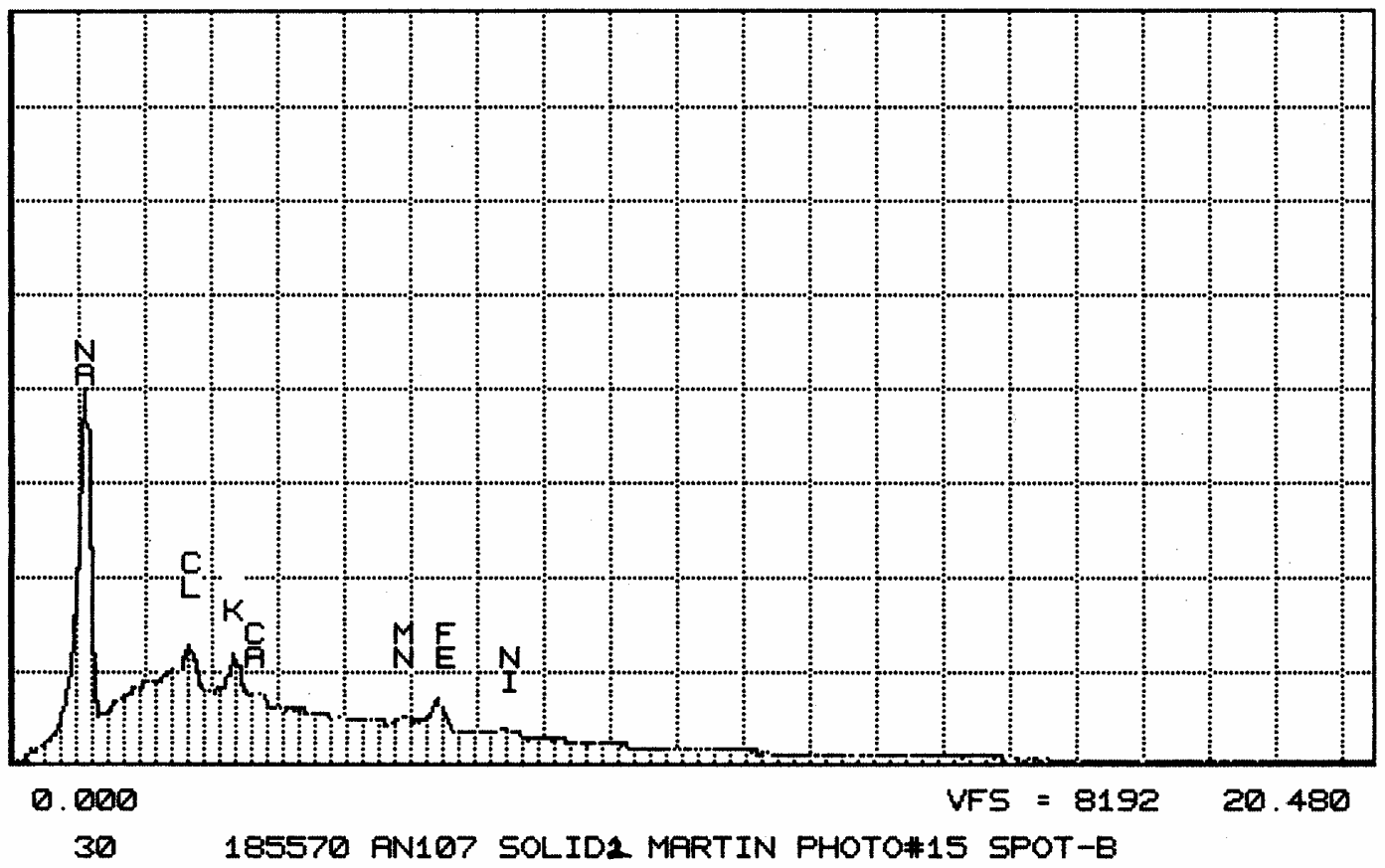

Figure B- 6. AN-107 Solid 2 Spot-A (top) and Spot-B (bottom) 


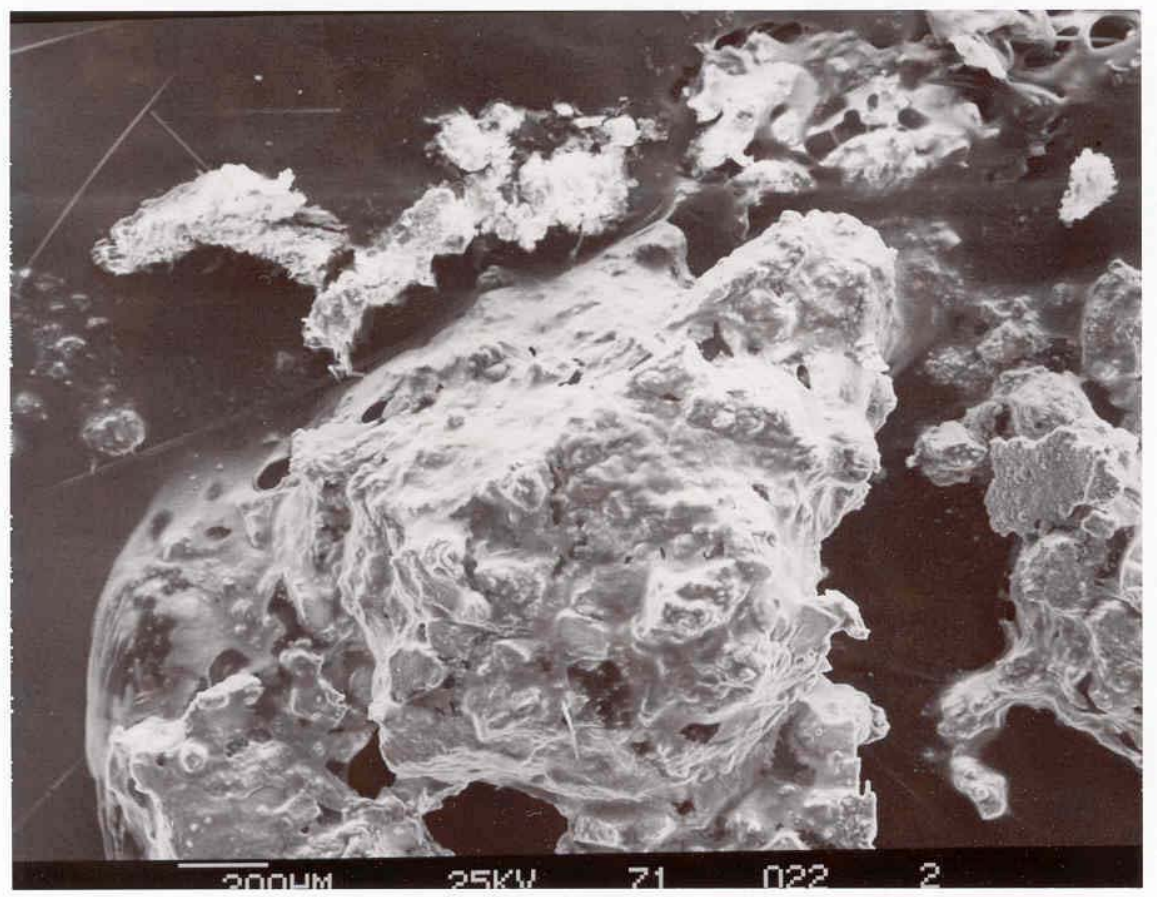

Figure B- 7. AN-107 Solid 3 50x Magnification

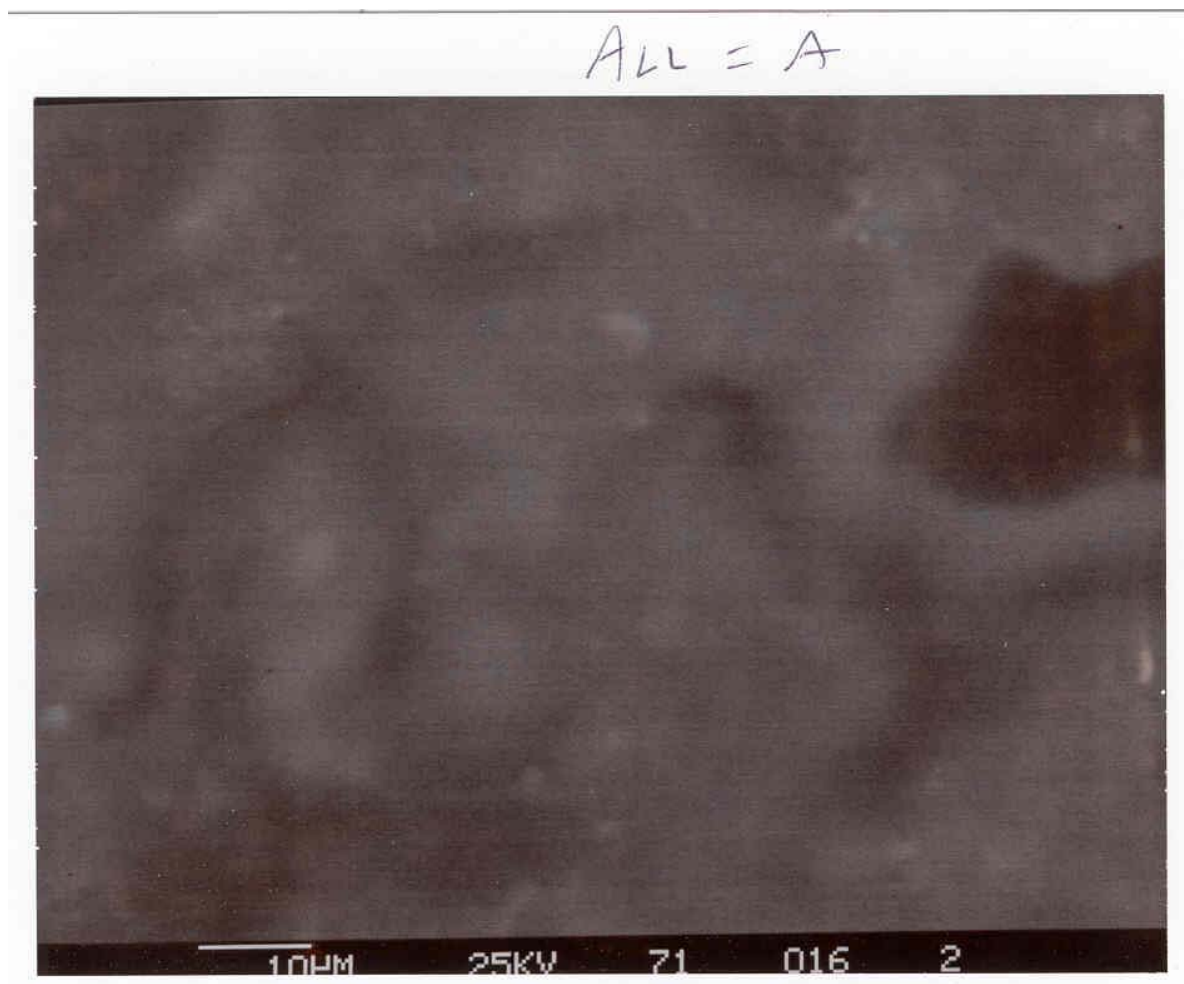

Figure B- 8. AN-107 Solid 3 1000x Magnification 
TN-SSO2 WSRC CSEM.

Cursor: $0.000 \mathrm{keV}=0$

MON 30-SEP-Q2 15:05

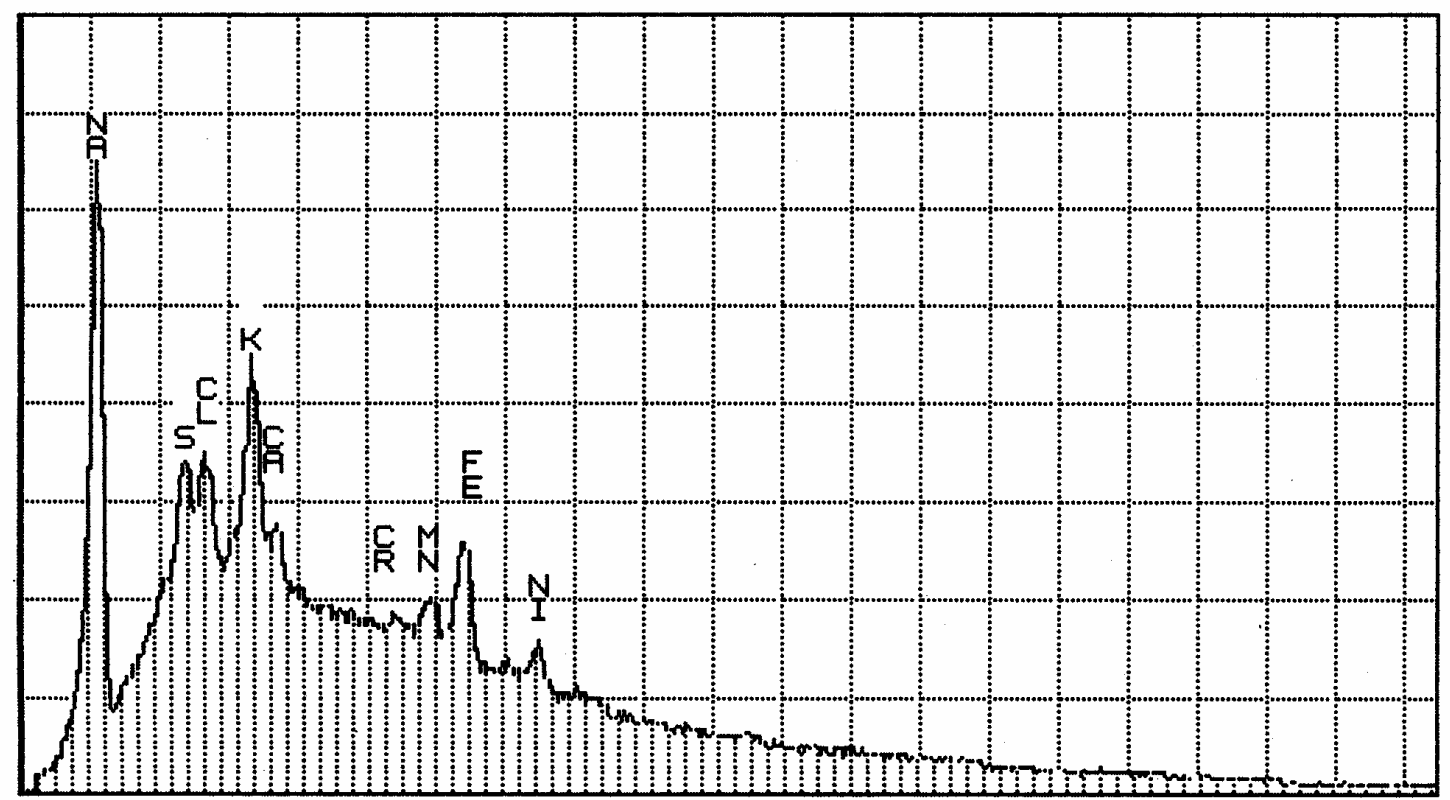

0.000

VFS $=2048 \quad 20.480$

30

185571 FN107 SOLID3 MRRTIN PHOTO\#16 SPOT-A

Figure B- 9. AN-107 Solid 3 Spot-A 


\section{APPENDIX C. RAW ANALYTICAL RESULTS}

The large volume of raw analytical data is available upon request. 
This page intentionally left blank. 